Poliklinik für Zahnärztliche Prothetik

(Prof. Dr. med. dent. R. Bürgers)

im Zentrum Zahn-, Mund- und Kieferheilkunde

der Medizinischen Fakultät der Universität Göttingen

\title{
Parakrine Beeinflussung der Genexpression in vitro von chondrogenen Zellen in der Osteoarthrose
}

\author{
INAUGURAL - DISSERTATION
}

\author{
Zur Erlangung des Doktorgrades \\ der Medizinischen Fakultät der \\ Georg-August-Universität zu Göttingen
}

vorgelegt von

Phillip Marks

aus

Uelzen

Göttingen 2015 
Dekan:

I. Berichterstatter:

II. Berichterstatter:

III. Berichterstatterin:
Prof. Dr. rer. nat. H. K. Kroemer

Prof. Dr. med. N. Miosge

Prof. Dr. rer. nat. R. Behr

Prof. Dr. hum. biol. M. Schön 


\section{Einleitung}

1.1 Osteoarthrose: Epidemiologie, Klinik, Therapie

1.2 Gesunder hyaliner Gelenkknorpel

1.2.1 Grundlagen der Charakteristika des Gelenkknorpels 3

1.2.2 Aufbau der extrazellulären Matrix (EZM) 4

1.2.3 Proteoglykane

$\begin{array}{ll}\text { 1.2.4 Kollagene } & 6\end{array}$

$\begin{array}{ll}\text { 1.2.5 Nicht-kollagene Proteine } & 8\end{array}$

1.3 Die Chondrozyten und der Prozess der Chondrogenese $\quad 8$

1.3.1 Die Chondrozyten $\quad 8$

1.3.2 Die Entwicklung hyalinen Gelenkknorpels - der Prozess der Chondrogenese 9

1.3.3 Die Matrixsynthese im Rahmen der Chondrogenese 10

1.3.4 Transkriptionsfaktoren in der Chondrogenese - Bedeutung und Funktion $\quad 10$

1.3.5 Parakrine Einflüsse und Kontrolle der Chondrogenese 11

1.3.6 Artikuläre Chondrozyten im gesunden Gelenkknorpel 14

1.4 Der Gelenkknorpel im Prozess der Osteoarthrose 14

1.4.1 Die Pathogenese der Osteoarthrose 14

1.4.2 Entwicklungen der Chondrozyten und Degradation der extrazellulären Matrix in der Osteoarthrose

$\begin{array}{ll}\text { 1.5 Differenzierungsfähige Zellen und tissue engineering } & 17\end{array}$

1.5.1 Differenzierungsfähige Zellen aus osteoarthrotischem Gelenkknorpel - chondrogene Progenitorzellen (CPC)

$\begin{array}{ll}\text { 1.5.2 Mesenchymale Stammzellen } & 19\end{array}$

1.5.3 Chondrozytäre Differenzierung in vitro - Kulturprobleme und - anforderungen $\quad 20$

1.6 Aufgabenstellung und Ziele dieser Arbeit 23 
2.1 Allgemeines zur Methodik und dem Versuchsaufbau

2.2 Zellreihen und Zellkultur $\quad 25$

2.2.1 Mesenchymale Stammzellen (MSC) 25

2.2.2 Chondrozyten aus gesundem Gelenkknorpel $(\mathrm{gG}) \quad 25$

2.2.3 Chondrogene Progenitorzellen (CPC) 26

2.2.4 Zellkultivierung und Passagierung 26

$\begin{array}{ll}\text { 2.2.4.1 Zellkultur } & 26\end{array}$

2.2.4.2 Passagierung der Zellen in Kultur $\quad 28$

2.2.5 Aufbau einer 3D-Kultur der Zellen in Alginat 28

2.3 Aufbau der Versuchsanordnungen $\quad 29$

2.3.1 Versuchsaufbau der 3D-Ko-Kultur 29

2.3.2 Versuchsaufbau der 3D-Kultur mit konditionierten Zellkulturmedien 31

$\begin{array}{ll}\text { 2.3.3 Kontrollkulturen } & 34\end{array}$

2.4 Isolation der RNA aus den Versuchszellen $\quad 34$

2.4.1 Lyse der Alginatkugeln $\quad 34$

2.4.2 RNA-Isolation $\quad 34$

2.4.3 Photometrische Bestimmung der RNA-Konzentration 35

2.4.4 Reverse Transkription: Umschreiben der mRNA in cDNA 36

2.5 Quantitative real time Reverse Transkription-Polymerase-Kettenreaktion (qRT-PCR) 37

$\begin{array}{ll}\text { 2.5.1 Funktion und Ablauf der qRT-PCR } & 37\end{array}$

2.5.2 PCR-Programm

2.5.3 Erstellung der Oligonukleotid-Primer $\quad 40$

2.5.4 Gradienten-PCR und Ermittlung der Annealing-Temperatur der Primer $\quad 40$

2.5.5 Sequenzierung der PCR-Produkte zur Analyse der funktionellen Spezifität 42

2.6 Auswertung und statistische Analyse $\quad 42$

2.6.1 Auswertung und Statistik 42

2.6.2 Housekeeping-Gene 43 
3.1 Reaktionen im Expressionsverhalten der gG-Zellen in 3D-Ko-Kultur mit CPC und MSC sowie im Einfluss von mit Knorpel aus OA-Defekten konditioniertem Medium

3.1.1 Der Einfluss von CPC auf gG-Zellen in 3D-Ko-Kultur

3.1.2 Der Einfluss von R-konditioniertem Medium auf gG-Zellen in Alginatkultur

3.1.3 Der Einfluss von MSC auf gG-Zellen in 3D-Ko-Kultur

3.2 Das Expressionsverhalten von CPC und MSC in 3D-Ko-Kultur mit gG-Zellen 48

3.2.1 Die Effekte von gG-Zellen auf das Expressionsmuster der CPC in 3D-Ko-Kultur $\quad 48$

3.2.2 Die Effekte von gG-Zellen auf das Expressionsmuster der MSC in 3D-Ko-Kultur

3.2.3 Zusammenfassung der parakrinen Interaktionen von gG-Zellen und MSC in gemeinsamer 3D-Ko-Kultur

3.3 Die Ergebnisse der gemeinsamen 3D-Ko-Kultur von CPC und MSC

3.3.1 Das Expressionsverhalten von MSC in 3D-Ko-Kultur mit CPC

3.3.2 Das Expressionsverhalten von CPC in 3D-Ko-Kultur mit MSC

3.4 Konditioniertes Medium aus G- und R- Bereichen osteoarthrotischen Gelenkknorpels Einfluss auf das Expressionsverhalten von CPC, gG-Zellen und MSC in Alginatkultur

3.4.1 Die Wirkung R- und G- konditionierter Medien auf das Expressionsverhalten von MSC 54

3.4.2 Die Wirkung R- und G- konditionierter Medien auf das Expressionsverhalten von gGZellen

3.4.3 Die Wirkung R- und G- konditionierter Medien auf das Expressionsverhalten von CPC 56

3.5 Unterschiede und Parallelen in den parakrinen Wirkungen der verschiedenen 3D-Ko-

Kulturen und Alginatkulturen in R- und G-konditionierten Medien

3.5.1 Vergleich der Wirkung von Alginatkultur in G-konditioniertem Medium und R-

konditioniertem Medium auf CPC, MSC und gG-Zellen

3.5.2 Die Wirkung von CPC-3D-Ko-Kultur und Alginatkultur in R-konditioniertem Medium auf MSC und gG-Zellen 
Inhaltsverzeichnis

$\begin{array}{lr}\text { 4. Diskussion } & 60\end{array}$

4.1 Chondrozyten $(\mathrm{gG})$ als parakriner Mediator in 3D-Ko-Kultur mit MSC und CPC $\quad 60$

4.1.1 Der parakrine Einfluss von Chondrozyten (gG) auf das Genexpressionsmuster von MSC in 3D-Ko-Kultur

4.1.2 Der parakrine Einfluss von Chondrozyten $(\mathrm{gG})$ auf das Genexpressionsmuster von CPC in 3D-Ko-Kultur

4.2 Parakrine Einflüsse von MSC und CPC auf das Genexpressionsmuster von Chondrozyten 66

4.2.1 CPC als parakriner Mediator - Einfluss auf die Expression von osteogenen und chondrozytären Markergenen von gG-Zellen in 3D-Ko-Kultur

4.2.2 MSC als parakriner Mediator - Modulation des Genexpressionsmusters von gG-Zellen in 3D-Ko-Kultur 


\section{Einleitung}

\subsection{Osteoarthrose: Epidemiologie, Klinik, Therapie}

Funktionsstörungen und Erkrankungen des Bewegungsapparates sind bei einem Vergleich chronischer Erkrankungen mit dem größten Verlust von Lebensqualität assoziiert. Die höchste Inzidenz in dieser Gruppe weist die Osteoarthrose (OA) auf (Reginster und Khaltaev 2002). Sie ist die weltweit häufigste Gelenkerkrankung und geht neben einer erheblichen Beeinträchtung der individuellen Lebensqualität mit progredient verminderter Leistungsfähigkeit einher (Woolf und Pfleger 2003; Felson 2006).

Die Symptomatik ist charakterisiert durch einen signifikanten Funktionsverlust des betroffenen Gelenkes. Zunehmende Beweglichkeitseinschränkungen, Schwellungen und Schmerzen, die anfangs als sogenannter Anlaufschmerz mit der Dauer einer Bewegung abnehmen, in fortgeschrittenen Stadien der OA jedoch zu einem dauerhaften Leiden werden, sind mit dem klinischen Bild der Erkrankung verbunden (Jordan et al. 2003; Goldring und Goldring 2006).

Die Osteoarthrose ist eine multifaktoriell bedingte, progrediente Degradation des Gelenkknorpels. Sie resultiert in einer zunehmenden Erosion der Gelenkflächen. Gesunder Gelenkknorpel ist ein hochspezialisiertes Bindegewebe, aufgebaut aus einer stark hydrierten extrazellulären Matrix (EZM) und Knorpelzellen, den Chondrozyten, als einzigem residenten Zelltyp (McDevitt 1973; Mow et al. 1984). Gelenkknorpel ermöglicht schmerzfreie Bewegungen durch eine milde, reibungsarme Übertragung und Verteilung der Kräfte zwischen den artikulierenden Knochen. Diese schützt er vor der direkten Einwirkung der mechanischen Belastungen, die auf und über das jeweilige Gelenk wirken (Muir 1995; Otte 2001). Der Gelenkknorpel verliert im Verlauf der OA seine charakteristischen Eigenschaften und damit die Möglichkeit, seine Funktion suffizient aufrecht zu erhalten (Martinek 2003; Goldring und Goldring 2007).

Für den Metabolismus der Matrix sind die Chondrozyten verantwortlich: sie gewährleisten einen geregelten, ausgewogenen Auf- und Abbau der extrazellulären Matrix (Kuettner 1992; Muir 1995). Die Regenerationsfähigkeit hyalinen Gelenkknorpels durch die Knorpelzellen ist im Falle von Läsionen jedoch gering (Otte 2001; Van der Kraan 2012). Im Prozess der OA geht die Balance zwischen chondrozytärem Matrixkatabolismus und -anabolismus verloren. Die Konsequenz ist eine fortlaufende Veränderung in der Matrixzusammensetzung, ihrer Funktionsfähigkeit und ihrer Stabilität. Das Resultat der intrinsischen Reparaturversuche ist ein untypischer Faserknorpel, dessen Eigenschaften 
den Anforderungen an Gelenkknorpel nicht standhalten. In betroffenen Gelenkbereichen kommt es $\mathrm{zu}$ einer progredienten Zerstörung von Gewebe und Minderung der Knorpelschicht in Masse und Höhe (Horton et al. 2006; Goldring und Marcu 2009). Die Auswirkungen der zunehmend direkten Krafteinwirkungen auf die gelenkbildenden knöchernen Strukturen lassen sich radiologisch evaluieren. Es kommt zu einer zunehmenden Sklerosierung der subchondralen Knochenschicht, einer Verschmälerung des Gelenkspaltes, Wachstum von Osteophyten, subchondralen Knochenzysten, später Geröllzysten im Tibiakopf und den Femurkondylen. Das Endstadium beschreibt die Destruktion des Gelenkes (Kellgren und Lawrence 1957).

Risikofaktoren für die Entstehung einer Osteoarthrose lassen sich generell in 3 Gruppen gliedern: mechanische Veränderungen in der Kraftübertragung, systemische und hereditäre Gegebenheiten sowie Alterseffekte (Goldring und Goldring 2006). Das Alter stellt eine besonders wichtige Prädisposition dar. Entgegen der lange Zeit vorherrschenden Meinung ist die Arthrose jedoch keine einfache Verschleisserkrankung. Altersveränderungen im Gelenkknorpel sind universell zu beobachten, diese resultieren aber nicht zwangsläufig in der Entwicklung einer Osteoarthrose (Carrington 2005; Loeser 2009). Bedingt durch die demographische Entwicklung und die zunehmende Lebenserwartung wird die Osteoarthrose in den nächsten Jahren von weiter wachsender medizinischer und sozioökonomischer Bedeutung sein. So wird beispielsweise davon ausgegangen, dass die OA im Jahr 2020 die viert-häufigste Ursache von Erwerbsunfähigkeit sein wird (Woolf und Pfleger 2003).

Die Therapiemöglichkeiten der OA sind momentan begrenzt. Die derzeitigen Kenntnisse über Ereignisse, Einflüsse und Abläufe im Pathomechanismus der Erkrankung sind nicht ausreichend. Die symptomatische Therapie bezieht sich vornehmlich auf Schmerzreduktion und Bewegungserhaltung. Bei nahezu allen Patienten mit fortgeschrittener OA ist der operative Gelenkersatz als Therapie der Wahl nötig (Lohmander und Roos 2007; Diekman und Guilak 2013). Allen kurativen therapeutischen und experimentellen Ansätzen gemeinsam ist das Ziel, den degenerativen Progress aufzuhalten und eine Möglichkeit der Rekonstruktion des Gewebes zu schaffen. Das tissue engineering als Therapie der Knorpeldegradation hat in diesem Gebiet eine herausragende Stellung. Jedoch fehlen die endgültigen Möglichkeiten, Gelenkknorpel mit Zellen biologisch und langfristig funktionell gleichwertig $\mathrm{zu}$ synthetisieren und transplantationsfähig zu gestalten oder intraartikulär zu resynthetisieren (Caplan 2007; Koelling und Miosge 2009; Diekman und Guilak 2013). 
Vor diesem Hintergrund steht der Chondrozyten - als Produzenten der gesamten Knorpelmatrix - im Mittelpunkt des Interesses der Osteoarthroseforschung. Sie stellen mögliche therapeutische Ressource und Äquivalent des pathogenetischen Angriffspunktes dar. Ihre Differenzierung, Interaktionen und Dedifferenzierung im Krankheitsfall sind bisher nur unvollständig aufgeklärt. Innerhalb des kranken artikulären Knorpels in der OA wurde neben den residenten Chondrozyten ein neuer Zelltyp entdeckt und charakterisiert, die chondrogenen Progenitorzellen (CPC) (Koelling et al. 2009). Aufgrund seiner Avaskularität ist für den hyalinen Knorpel als parakrines Organ Diffusion ein bedeutender Bestandteil des Metabolismus (Kuettner 1992; Martel-Pelletier et al. 2008). Knorpelzellen selbst und die Umgebung im gesamten synovialen Gelenk stehen über das Dialysat Synovialflüssigkeit miteinander in Verbindung und interagieren auf parakrinem Weg. Schon die Chondrogenese - der embryonale Vorgang in der Skelettbildung - von mesenchymalen Stammzellen $\mathrm{zu}$ ausdifferenzierten Chondrozyten in vivo wird über zelluläre und gewebeabhängige trophische Faktoren reguliert (DeLise et al. 2000). Das Gleiche gilt für den in der Entwicklung folgenden Prozess der enchondralen Ossifikation. In diesem Entwicklungsprozess wird über die Schritte hypertropher Differenzierung, Änderung der Syntheseleistung und abschließender Apoptose der Chondrozyten der Umbau der knorpeligen Skelettanlagen zu Knochen gestaltet.

\subsection{Gesunder hyaliner Gelenkknorpel}

\subsubsection{Grundlagen der Charakteristika des Gelenkknorpels}

Der gesunde Gelenkknorpel besteht aus einer stark hydrierten extrazellulären Matrix und beherbergt hochdifferenzierte Chondrozyten als einzigen Zelltyp. Deren Anteil beansprucht unter 5\% des Gewebevolumens (Kuettner 1992; Buckwalter und Mankin 1998). Makroskopisch erscheint er hell, glatt, leicht weiss-bläulich schimmernd und nahezu transluzent - namensgebend war das griechische Wort für Glas: hyalos.

Er überzieht in der mit Synovialflüssigkeit gefüllten Gelenkkapsel die Enden der knöchernen Strukturen, die über das jeweilige Gelenk funktionell und beweglich miteinander verbunden sind. Somit kann es als das Gewebe betrachtet werden, welches bei Artikulationen direkt miteinander interagiert (Mow et al. 1984).

Hyaliner Knorpel zeichnet sich durch die Kombination von Steifigkeit, Elastizität und geringer Reibung aus. Physiologisch stellt er, geschmiert durch Synovialflüssigkeit, eine reibungsarme Gelenkfläche dar, die erheblichem Druck und Scherkräften standhält. Durch 
seine Eigenschaft, reversibel elastische Verformungen einzugehen, ist er in der Lage, starke Druckbelastungen von bis zu $150 \mathrm{~kg} / \mathrm{cm}^{2}$ abzudämpfen (Mow et al. 1984; Otte 2001).

Im adulten Gelenkknorpel sind keine Blutgefäße, Nervenfasern und Lymphgefäße vorhanden (Cameron und Robinson 1958; Poole 1997). Die nutritive und metabolische Versorgung, sowie die Entsorgung von Stoffwechsel- und Abbauprodukten erfolgen via Diffusion innerhalb der Knorpelmatrix und über die Synovialflüssigkeit (Muir 1995, Martel-Pelletier et al. 2008). Chondrozyten entbehren direkter Zell-Zell-Kontakte. Daraus folgt, dass auch die interzelluläre Kommunikation zu großen Teilen per diffusionem, autooder parakrin durch die Matrix erfolgt (Kuettner 1992; Dijkgraaf et al. 1995). Vermittelt werden parakrine Interaktionen und andere systemische oder lokale Einflüsse auf die Chondrozyten über Wachstums- und Differenzierungsfaktoren, Entzündungsmediatoren, Hormone, Zytokine, End- und Abbauprodukte aus der Matrixynthese und Matrixfragmente bei deren Degeneration (Sandell 2007; Goldring und Marcu 2009). Einen weiteren wichtigen Mediator stellt mechanische Belastung dar, welche über die Matrix an die Chondrozyten weitergeleitet wird. Diese Zell-Matrix-Interaktion vermittelt neben dem Diffusionsweg den Chondrozyten biomechanische Informationen aus und über die Umgebung (Kuettner 1992; Goldring und Goldring 2007).

\subsubsection{Aufbau der extrazellulären Matrix (EZM)}

Die Funktion und Integrität des Gelenkknorpels gewährleistet der Aufbau der EZM. Für die Synthese und Aufrechterhaltung dieses makromolekularen Rahmens sind die Chondrozyten verantwortlich (Muir 1995; Sandell 2007).

Ultrastrukturell ist die EZM aus einem Kollagenfasergeflecht aufgebaut, in das ein großvolumiges Netzwerk aus Proteoglykanen eingebunden ist. Die charakteristischen Hauptvertreter im hyalinen Knorpel sind Kollagen Typ II und das Proteoglykan Aggrecan (Kuettner 1992; Poole 1997). Kollagene, Proteoglykane und freie Elektrolyte machen zusammen 92\% des Knorpel-Trockengewichtes aus (Maroudas et al. 1980). Weitere Bestandteile sind nicht-kollagene Proteine und Glykoproteine, die zur Organisation und Stabilisierung beitragen (Buckwalter und Mankin 1998; Miosge et al. 2004).

In vivo stellt Wasser, vor allem durch Proteoglykane gebunden, eine Hauptkomponente der EZM dar. Sein Anteil am nativen Gewicht beträgt circa 70\%-75\% (Mow et al. 1984; Kuettner 1992). 


\subsubsection{Proteoglykane}

Proteoglykane sind Makromoleküle der EZM, deren kennzeichnende Eigenschaft ihre hohe Wasserbindungskapazität ist. Diese verleiht ihnen essentielle und prägende Funktion in Biochemie, Physiologie und Mechanik des Knorpels (Iozzo 1998; Otte 2001). Die Proteoglykane nehmen nahezu den gesamten interfibrillären Raum zwischen den Kollagenfasern ein (Maroudas et al. 1980; Martinek 2003). Proteoglykane sind involviert in die Organisation von Aufbau und Struktur der Knorpelmatrix. Sie nehmen Einfluss auf die Synthese und Fibrillogenese von Kollagen sowie auf Proliferationsvorgänge und Metabolismus der Chondrozyten (Roughley 2001). Die kürzere Halbwertszeit der artikulären Proteoglykane von Tagen bis $\mathrm{zu}$ wenigen Wochen bedingt einen höheren Umsatz im Matrixsynthesestoffwechsel, verglichen mit Kollagen Typ II, dessen Halbwertszeit bei bis zu mehreren Jahren liegt (Kuettner 1992; Goldring und Marcu 2009). Aufgebaut sind Proteoglykane aus einem zentralen Protein (core protein), an welches eine Vielzahl von Seitenketten kovalent gebunden ist (Von der Mark und Glückert 1990; Iozzo 1998). Über eine amino-terminale Domäne können Zentral-Proteine mehrerer PG an ein Hyaluronsäuremolekül binden (Roughley 2001). Die Seitenketten sind Glykosaminoglykane, vor allem Chondroitin-6-Sulfat und Keratansulfat sowie Oligosaccharide (Iozzo 1998; Roughley 2006). Aufgrund ihrer zusätzlichen negativen Ladungen machen sie das Proteoglykanmolekül zu einem Polyanion, worin sich die hohe Bindungsfähigkeit für Wasser, Ionen und andere Moleküle begründet (Kuettner 1992).

Im Gelenkknorpel ist Aggrecan mit einem Anteil von 90\% das wichtigste und häufigste Proteoglykan (Muir 1995; Iozzo 1998). Seine Synthese ist charakteristisch für den gesunden hyalinen Knorpel (Kuettner 1992; Buckwalter und Mankin 1998). In einem Aggrecanmolekül sind über 100 Chondroitinsulfat-, Keratansulfat- und Oligosaccharidketten gebunden (Roughley 2001). Durch diesen Aufbau nimmt dieses Proteoglykan eine flaschenbürstenartige Form an (Muir 1995; Otte 2001). Über linkProteine binden bis zu 200 der Aggrecanmonomere nicht-kovalent über ihr jeweiliges Zentralprotein an ein Hyaluronsäuremolekül und lagern sich so zu den namensgebenden Aggregaten zusammen (Roughley 2006). Die Proteoglykane, insbesondere Aggrecan, spielen neben ihrer maßgeblichen biomechanischen Funktion durch Interaktionen mit anderen Komponenten der EZM und den Chondrozyten auch eine wichtige Rolle in der Zell-Matrix-Kommunikation (Iozzo 1998; Roughley 2001). Hyaluronsäuremoleküle und kleinere Proteoglykane selbst sind durch Quervernetzungen an der Verbindung des Proteoglykan-Netzwerkes beteiligt und über Rezeptoren mit den Chondrozyten bis in 
deren direkt umgebende Matrix verbunden (Iozzo 1998; Kruegel und Miosge 2010). Unter anderem werden im Proteoglykan-Netzwerk Wachstumsfaktoren gehalten und gespeichert (Poole 1997; Buckwalter und Mankin 1998). Proteoglykane interagieren mit den Wachstumsfaktoren und zugehörigen Rezeptoren, wodurch sie in die Regulation von Signalwegen innerhalb des Knorpels involviert sind (Iozzo 1998; Roughley 2006; Kruegel und Miosge 2010).

Aggrecan ist knorpelspezifisch und mit $215 \mathrm{kDa}$ relativ groß. Andere Proteoglykane im Knorpel wie Dekorin, Biglycan, Perlecan und Fibromodulin sind mit Größen unter 100 $\mathrm{kDa}$ deutlich kleiner. Ihnen wird eine das großmolekulare Proteoglykan-Netzwerk verknüpfende und stabilisierende Funktion zuteil und sie spielen eine wichtige Rolle in der Organisation von Kollagenfibrillen (Miosge et al. 1994; Iozzo 1998).

\subsubsection{Kollagene}

Kollagene haben einen Anteil von 50-60\% am Trockengewicht des hyalinen Knorpels und repräsentieren den größten Anteil an den Knorpelproteinen (Bruckner und Van der Rest 1994; Eyre 2002). Sie bilden ein unlösliches, dreidimensionales Netzwerk, das im subchondralen Knochen verankert ist. Dieses Gerüst ist für die Struktur und Organisation der Matrix essentiell und für die Zug- und Reißfestigkeit des Gelenkknorpels verantwortlich. Es bildet den Widerstand gegenüber dem osmotischen Expansionsdruck, der durch die starke Hydratationsfähigkeit des Proteoglykangeflechtes entsteht (McDevitt 1973, Dijkgraaf et al. 1995, Martinek 2003).

Kollagen Typ II bildet 90\% des kollagenen Netzwerkes in hyalinem Knorpel und stellt das charakteristische Kollagen des gesunden Gelenkknorpels dar. Zugleich ist es neben Aggrecan das charakteristische EZM Molekül des hyalinen Knorpels. Seine Eigenschaften prägen die Funktion und Charakteristik des Kollagengerüstes in hyalinem Knorpel (Eyre 2002). Kollagen Typ XI hat einen Anteil von etwa 3\%, Typ VI und XI machen jeweils 12\% der Kollagene in gesundem hyalinen Knorpel aus (Buckwalter und Mankin 1998; Gelse et al. 2003). Mit noch geringerem Anteil im Gelenkknorpel zu finden sind Kollagene vom Typ III, V, XII, XIV und XVI (Mayne und Brewton 1993; Eyre 2002). Die biochemisch und mechanisch funktionelle Form der Kollagene stellen Fibrillen dar (Muir 1995; Gelse et al. 2003). Sie weisen seitliche Ladungen auf und sind auch mit den Matrixproteoglykanen physikalisch eng verbunden. Kollagen Typ II bildet homotrimere Fibrillen, diese bestehen aus jeweils drei gleichen alpha-Ketten. Das Netzwerk von Typ-IIKollagenfibrillen wird durch Querverbindungen, vor allem mit Kollagen Typ XI und IX, 
stabilisiert. Diese drei Kollagene können in diesem Gerüst auch gemeinsame, heterotrimere Fibrillen mit hoher Festigkeit ausbilden (Muir 1995; Eyre 2002).

Durch zonal unterschiedliche Ausrichtungen der Fibrillen entsteht in einigen dieser Geflechte eine arkadenförmige Struktur (Bullough und Goodfellow 1968).

Kollagen IX stellt mit seiner COL3-Domäne eine molekulare Brücke zwischen benachbarten Fibrillen und anderen Matrixkomponenten wie Proteoglykanen und nichtkollagenen Proteinen dar. Neben den kovalenten Verbindungen zu Kollagen Typ II sind auch Vernetzungen mit anderen Kollagen Typ IX-Molekülen vorhanden (Wu et al 1992; Eyre 2002). Kollagen Typ IX und Kollagen Typ XI sind an der Regulation von Synthese und Organisation der Fibrillen beteiligt (Poole 1997; Eyre 2004). Durch ihre Rolle beim Aufbau und der Verknüpfung des Kollagengerüstes tragen beide Kollagene Verantwortung für dessen Integrität und Stabilität, die zum langfristigen Erhalt der Architektur und Funktion des Gelenkknorpels nötig ist (Wu et al. 1992; Eyre 2004).

Kollagen Typ VI findet sich insbesondere in der perizellulären Matrix. Es umgibt die Zellen und schützt sie vor mechanischer Schädigung. Neben dem Knorpel ist Kollagen Typ VI in vielen, auch fibrocartilaginären Geweben präsent wie Meniscus und Discus intervertebralis (Poole 1997; Eyre 2002). Durch seine Verknüpfungen zu Chondrozyten und dem Kollagennetzwerk wirkt Kollagen Typ VI an der Verbindung von territorialer und interterritorialer Knorpelmatrix mit, wodurch es zur Zell-Matrix-Interaktion beiträgt (Buckwalter und Mankin 1998).

Kollagen Typ X kommt im normalen hyalinen Knorpel nur in der territorialen Matrix der kalzifizierten Zone vor (Muir 1995; Martinek 2003). Es spielt eine wichtige Rolle bei der enchondralen Ossifikation, ist in hypertrophem Gelenkknorpel sowie während dessen Kalzifizierungsvorgängen an der Wachstumsplatte zu finden (Lefebvre und Smits 2005). Dies macht ihn zu einem Marker der hypertrophen Differenzierung von Chondrozyten, wie sie während der enchondralen Ossifikation zu sehen ist, aber auch im Krankheitsprozess der OA beobachtet wird (Von der Mark et al. 1992; Goldring und Marcu 2009).

Kollagen Typ I wurde in Gelenkknorpel nur in kleinsten Mengen und nur in der feinen Schicht an der Gelenkoberfläche (Lamina splendens) nachgewiesen. Es gilt nicht als Bestandteil einer gesunden hyalinen Knorpelmatrix, sondern ist ein wichtiger Baustein von Faserknorpel sowie der EZM in Haut, Knochen, Sehnen und Bändern (Eyre 2002; Tesche und Miosge 2005). Während der Chondrogenese wird Kollagen Typ I von undifferenzierten chondrogenen mesenchymalen Vorläuferzellen exprimiert (DeLise et al. 2000; Lefebvre und Smits 2005). In Bezug auf den Gelenkknorpel liegt die Bedeutung in 
seiner gesteigerten Synthese und Expression in fibrösem faserknorpelähnlichem Ersatzgewebe, das im Rahmen von Reparaturversuchen bei Schädigungen des Knorpels und im Prozess der OA zu finden ist (Von der Mark und Glückert 1990; Nerlich et al. 1993; Miosge et al. 2004). Eine gesteigerte Expression und Synthese von Kollagen Typ I zeigt sich auch bei dedifferenzierten Chondrozyten in vitro (Miosge et al. 2004; Grässel und Ahmed 2007). Seine gesteigerte Expression und Synthese gelten als wichtige Marker einer derartigen chondrozytären Dedifferenzierung. Diese Differenzierungsprozesse spielen sowohl in Zellkulturbedingungen als auch in der OA eine Rolle (Tesche und Miosge 2005; Grässel und Ahmed 2007).

\subsubsection{Nicht-kollagene Proteine}

Mit einem Anteil von etwa 15\% am Trockengewicht ist die heterogene Gruppe der nichtkollagenen Proteine und Glykoproteine am Aufbau des hyalinen Knorpels beteiligt (Roughley 2001). Ihre Aufgaben bestehen in der Organisation und Stabilisation der EZM und ihrer Anbindung an Chondrozyten. Ähnlich wie PG sind einige Vertreter der nichtkollagenen Proteine und Glykoproteine fähig, interstitielles Wasser zu binden (Martinek 2003). Wichtige Beispiele und funktionell zu Teilen verstanden sind das im ProteoglykanAufbau zur Aggregatbildung notwendige link-Protein, Anchorin, welches eine Rolle in der Verbindung der Chondrozyten zum Kollagennetzwerk spielt, sowie das vornehmlich in artikulärem Knorpel zu findende Glykoprotein COMP (cartilage oligomeric protein) (Buckwalter und Mankin 1998; Roughley 2001). Dieses nicht kollagene Protein fördert die Formierung und Organisation von Kollagenfibrillen und interagiert mit Kollagenen der EZM des Knorpels um die Struktur und Aufrechterhaltung derselben zu unterstützen (Goldring und Marcu 2009).

\subsection{Die Chondrozyten und der Prozess der Chondrogenese}

\subsubsection{Die Chondrozyten}

Chondrozyten sind hochdifferenzierte Zellen mesenchymalen Ursprungs. Als einziger existenter Zelltyp in gesundem Gelenkknorpel tragen sie die Verantwortung für die Synthese und die Homöostase der Knorpelmatrix. Diese Homöostase wird durch einen balancierten Auf- und Abbau der Matrix und seiner Bestandteile gewährleistet (Muir 1995; Goldring und Goldring 2006). Zu diesem Zweck produzieren Chondrozyten neben allen molekularen Bestandteilen der EZM auch Enzyme für deren geregelten Abbau sowie 
Zytokine und Wachstumsfaktoren zur autokrinen und parakrinen Regulation des zellulären Metabolismus (Van den Berg et al. 2001; Martel-Pelletier et al. 2008).

Das Verhältnis von Zellzahl zum Matrixvolumen ist im Gelenkknorpel, verglichen mit anderen Geweben, gering (Kuettner 1992; Archer und Francis-West 2003). Ausdifferenzierte Chondrozyten sind oval geformt. Die von perizellulärer Matrix umschlossene funktionelle Einheit aus einer oder zum Teil mehreren Knorpelzellen bezeichnet man als Chondron (Poole 1997). Jede Zelle beziehungsweise jedes Chondron ist primär für die Synthese und Aufrechterhaltung der EZM in ihrer direkten Umgebung verantwortlich (Poole 1997). Charakteristisch für hyalinen Knorpel ist die chondrozytäre Synthese der Matrixbestandteile Aggrecan und Kollagen Typ II, IX und XI (Muir 1995; Martel-Pelletier et al. 2008).

\subsubsection{Die Entwicklung hyalinen Gelenkknorpels - der Prozess der Chondrogenese}

Die Chondrogenese ist der Entwicklungsprozess mesenchymaler Vorläuferzellen zu reifen Chondrozyten und verläuft in komplex regulierten Phasen (DeLise 2000; Lefebvre und Smits 2005). Das Verständnis der Entstehung des artikulären Knorpels bietet die Möglichkeit wichtige Erkenntnisse und Ansätze zu Pathogenese sowie Therapiemöglichkeiten abzuleiten (Aigner und Gerwin 2007). Vor allem für die Entwicklung zellbasierter Therapien zur Rekonstruktion des Gelenkknorpels ist die Kenntnis der Regulation und Differenzierungsprozesse in der Chondrogenese entscheidend (Onyekwelu et al. 2009; Mabvuure et al. 2012).

Innerhalb der gemeinsamen knorpeligen Anlage des Skelettsystems werden in der Entwicklung verschiedene Differenzierungsvorgänge und Proliferationsprozesse der chondrogenen Zellen induziert (Lefebvre und Smits 2005; Goldring et al. 2006).

Am Anfang der Chondrogenese steht die Kondensation mesenchymaler Stammzellen zum dichten Knorpelblastem (Behonick und Werb 2003). Im Zentrum dieser Ansammlung chondrogener Progenitorzellen induzieren das umgebende Gewebe, Zell-ZellInteraktionen, Wachstumsfaktoren und Zytokine die weitere Differenzierung über PräChondrozyten zu Chondroblasten (DeLise 2000; Bobick et al. 2009). Aus den Chondroblasten entwickeln sich im weiteren Verlauf die ausdifferenzierten Chondrozyten. Einige periartikulär lokalisierte Chondrozyten werden postmitotisch proliferativ arretiert und in ihrem hochdifferenzierten Zustand stabilisiert (Muir 1995; Archer und Francis-West 2003). Diese Zellgruppe bildet dann, vom Knochen abgegrenzt, den artikulären hyalinen Knorpel. Für die Ausbildung des Gelenkknorpels unterlaufen wiederum einige distal und 
proximal gelegene Prä-Chondrozyten einen Differenzierungsprozess zurück zu mesenchymalem Muster mit folgender Apoptose. Die entstehenden kavitären Bezirke in der Gelenkregion werden anschliessend von den in Entwicklung befindlichen, bleibenden artikulären Chondrozyten genutzt (Lefebvre und Smits 2005).

Die reifen, prähypertrophen Chondrozyten der ruhenden und proliferativen Zone der Skelettanlage durchlaufen den Prozess der hypertrophen, terminalen Differenzierung zur enchondralen Ossifikation. In den terminal differenzierten Chondrozyten setzen entweder apoptotische Prozesse ein oder sie transdifferenzieren osteoblastär und beginnen zusammen mit einwandernden Osteoblasten mit der Synthese der endgültigen Knochenmatrix zum Ersatz des bereits kalzifierten Knorpels (Hunziker 1994; Behonick und Werb 2003).

\subsubsection{Die Matrixsynthese im Rahmen der Chondrogenese}

Im Verlauf der chondrozytären Differenzierung wird die Synthese von Aggrecan und den Kollagenen Typ II, IX und XI in den chondrozytären Zellen zunehmend gesteigert. Diese Matrixbestandteile sind charakteristisch für die EZM des hyalinen Knorpels und seiner Funktion (Kuettner 1992; Lefebvre und Smits 2005).

Parallel dazu nimmt die Synthese von Strukturproteinen ab, die als Marker von undifferenzierten Zellen gelten. Ein wichtiges Beispiel eines solchen Markerproteins ist Kollagen Typ I, das sich zu frühen undifferenzierten Phasen der Chondrogenese und im terminal differenzierten Stadien der Ossifikation zeigt (DeLise et al. 2000; Goldring et al. 2006).

Die Syntheseleistung der terminal hypertroph differenzierenden Chondrozyten wird charakterisiert durch Kollagen Typ X und alkalischer Phosphatase als Zeichen der zunehmenden Kalzifizierung der Matrix (Bobick et al. 2009). Während dieser Phase und dem folgenden knöchernen Umbau nimmt auch die Produktion von Kollagen Typ I wieder zu, dessen Anteil an der endgültigen organischen Knochensubstanz 80-90 \% ausmacht (Bobick et al. 2009).

\subsubsection{Transkriptionsfaktoren in der Chondrogenese - Bedeutung und Funktion}

Während der gesamten Knorpel- und Knochenentwicklung spielen die Transkriptionsfaktoren Sox9 und Runx2 eine entscheidende regulatorische Rolle. Zentrale Bedeutung für die Determination der Chondrogenese und seiner Differenzierungsschritte hat der Transkriptionsfaktor Sox9 (DeLise et al. 2000; Lefebvre und Smits 2005). Er 
reguliert unter anderem direkt die Expression der Gene von Kollagen Typ II und Aggrecan. (Goldring et al. 2006; Bobick et al. 2009). So steuert Sox9 vom Zeitpunkt der Kondensation die gesamte zelluläre Differenzierungkaskade und Genexpression bis zum reifen Chondrozyten (Archer und Francis-West 2003; Lefebvre und Smits 2005; Goldring et al. 2006). Mit Induktion der hypertrophen, terminalen Differenzierung und enchondralen Ossifikation übernimmt Runx2 die genetische Regulation der zellulären Prozesse in der Skelettentwicklung. Im Stadium des prähypertrophen Chondrozyten zeigt sich die Zunahme der Runx2-Expression über Werte der gleichzeitig verschwindenden Sox9Expression (Lefebvre und Smits 2005; Goldring et al. 2006). Der Transkriptionsfaktor Runx2 ist sowohl der Regulator der hypertrophen terminalen Differenzierung der Chondrozyten als auch der Entwicklung von Osteoblasten aus mesenchymalen Vorläuferzellen (Lefebvre und Smits 2005; Goldring et al. 2006; Aigner und Gerwin 2007).

\subsubsection{Parakrine Einflüsse und Kontrolle der Chondrogenese}

An der Chondrogenese sind Wachstumsfaktoren, Zytokine, Hormone und weitere lösliche Signalmoleküle an der Regulation und Beeinflussung der Differenzierung und Matrixsynthese entscheidend beteiligt.

$\mathrm{Zu}$ Beginn der Knorpelentwicklung und im kondensierten Knorpelblastem nimmt der fibroblast growth factor (FGF)-8 Einfluss auf die Kondensation und Proliferation der Zellen (DeLise et al. 2000; Umlauf et al. 2010). Über den parakrinen Mediator SonicHedgehog (Shh) werden neben der Kondensation auch frühe Differenzierungsschritte moduliert (DeLise et al. 2000). Ein bedeutsamer und ebenfalls früh wirksamer Effektor der chondrozytären Differenzierung, des Zellwachstums und späterer Apoptoseprozesse ist der transforming growth factor- $\beta$ (TGFß)-1 (Van den Berg et al. 2001; Goldring et al. 2006). Er agiert im Kondensationsprozess und ist ein wichtiger positiver Vermittler für die Synthese der EZM von Chondrozyten (Fortier et al. 2011). Die Gruppe der TGF-ß umfasst auch einige Mediatoren der bone morphogenic protein (BMP)-Familie. Sie sind in Differenzierungs, Wachstums- und Apoptoseprozessen der chondrozytären Entwicklung aktiv (DeLise et al. 2000). Insulin-like growth factors (IGF) -1 und -2 sind relevant für die Stimulation der zellulären Proliferation, und IGF-1 ist zusätzlich ein bekannter Aktivator der Matrixsynthese (Van den Berg et al. 2001). Schon der Beginn der chondrozytären Differenzierung steht, wie erwähnt, unter der regulatorischen Kontrolle von Sox9. Auf dessen Aktivierung haben sowohl Signalmoleküle aus der Gruppe der BMP als auch FGF 
Einfluss (Lefebvre und Smits 2005). Ebenso wirkt IGF-1 Sox9 vermittelt und stimuliert über dessen Aktivierung die Synthese von Proteoglykanen und Kollagen Typ II. BMP induzieren chondrogene Differenzierungsprozesse in mesenchymalen Vorläuferzellen und sind an der Regulation späteren Stadien der chondrozytären Reifung während der enchondralen Ossifikation beteiligt (Behonick und Werb 2003). Für die frühen Differenzierungsschritte zeigt sich BMP-4 verantwortlich, das seinerseits durch FGF-8 induziert wird. BMP-2 kann über Interaktionen mit anderen Transkriptionsfaktoren die Expression von Runx2 zu Beginn der Knorpelentwicklung unterdrücken und dadurch positiven Einfluß auf die chondrozytäre Entwicklung der Zellen nehmen. BMP-7 ist vor allem in proliferierenden Bereichen $\mathrm{zu}$ finden, wohingegen BMP-6 vor allem in der hypertrophen Zone des Knorpels aktivierend wirkt (Goldring et al. 2006). Über weitere Transkriptionsfaktoren vermitteln BMP zur enchondralen Ossifikation eine Aktivierung von Runx2 für die chondrozytäre Hypertrophie. FGF zeigen neben der im Verlauf frühen Wirkung auch an der Wachstumsplatte regulierende Beteiligungen und nehmen über mitogene Stimulation Einfluss auf das mit der folgenden Proliferation verbundene Längenwachstum (Umlauf et al. 2010). Dazu notwendige Proliferationsprozesse werden auch durch Insulin-like growth factor (IGF)-1 und -2 vermittelt (Van den Berg et al. 2001). Wnt-Signale zeigen sich in unterschiedlichen Phasen der Chondrogenese und initiieren in der frühen Chondrogenese die FGF-Produktion, zum Beispiel fördert Wnt-2 die Sekretion von FGF-8. Wnt haben $\mathrm{zu}$ diesen frühen Zeitpunkten der Chondrogenese differenzierungsfördernde Effekte und können die hypertrophe Differenzierung und damit die enchondrale Ossifikation blockieren, später aktive Wnt-Signale zeigen sich jedoch dann beteiligt an der hypertrophen Entwicklung der Chondrozyten (Tamamura et al. 2005; Goldring et al. 2006). Das von hypertrophen Chondrozyten produzierte parathormone related peptide (PTHrP) und Indian Hedgehog (Ihh), ein parakrines Signalmolekül aus der prähypertrophen Zone, sind in einer negativen Feedbackschleife verbunden (DeLise et al. 2000; Kobayashi et al. 2002). Ihh wird vornehmlich von prähypertrophen Chondrozyten produziert und ist ein osteogener Aktivator der Proliferation, dessen Wirkung über den feedback-Mechanismus mit PTHrP gesteigert wird. Ihh kann dabei die Produktion von PTHrP anregen, wird hingegen in der eigenen Synthese durch PTHrP vermindert. Die Wirkung von PTHrP zeigt sich in einer Verzögerung der Differenzierung von Chondrozyten zum prähypertrophen Phänotyp bei gleichzeitiger Aktivierung der Proliferation (Kobayashi et al. 2002; Lefebvre und Smits 2005). PTHrP kann als Suppressor der chondrozytären Hypertrophie angesehen werden. Die Balance von 
Differenzierung und Proliferation reguliert die Zellzahlen, die in die hypertrophe Differenzierung und damit enchondrale Ossifikation übergehen und die Zellzahlen, die durch Proliferation für Längenwachstum sorgen (Lefebvre und Smits 2005). Zu diesem Zweck interagieren auch weitere Signalwege, unter anderem existiert diesbezüglich ein Zusammenspiel von FGF und BMP (Minina et al. 2002; Goldring et al. 2006). Die zweite Komponente des Längenwachstums, die Produktion von EZM, wird von PTHrP, FGFs, BMPs und IGF-1 angeregt. Zum Ende der enchondralen Ossifikation koordiniert der vascular endothelial growth factor (VEGF), unterstützt durch FGF-18 und -9, die Angiogenese, das EZM-Remodelling und den Knochenaufbau in den hypertrophen und kalzifizierten Knochenanlagen (Gerber et al. 1999; Minina et al. 2002).

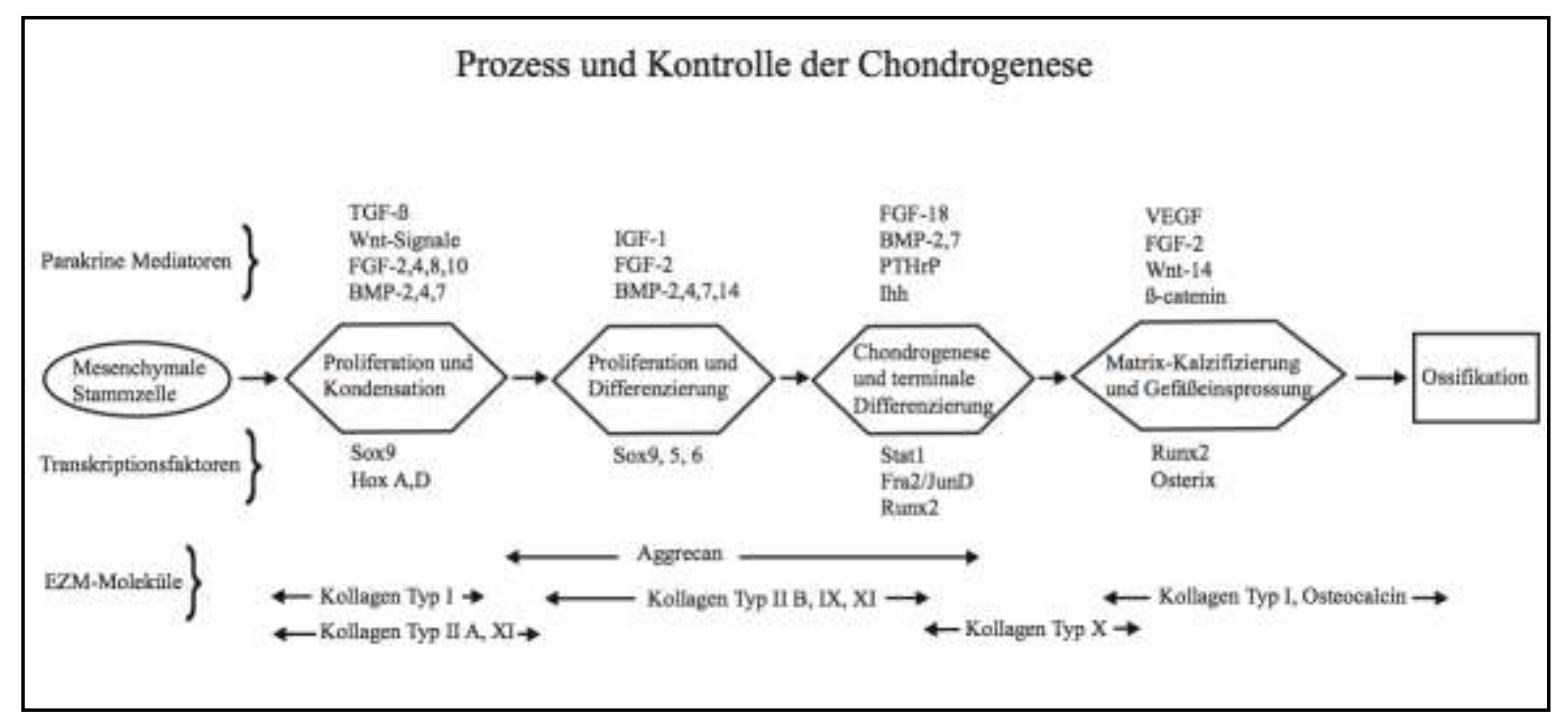

\section{Abbildung 1}

Der Prozess der Chondrogenese von der mesenchymalen Stammzelle bis zur enchondralen Ossifikation. Integrierte Darstellung einer Auswahl von an der Initiierung und Kontrolle beteiligten parakrinen Mediatoren und Transkriptionsfaktoren sowie der spezifische Verlauf der Synthese der EZM-Moleküle (modifiziert nach Goldring et al. 2006). 


\subsubsection{Artikuläre Chondrozyten im gesunden Gelenkknorpel}

Als wichtigste Voraussetzung für funktionellen Gelenkknorpel muss der hoch differenzierte Phänotyp artikulärer Chondrozyten im Idealfall über das gesamte Leben aufrecht erhalten werden (Muir 1995; Martinek 2003). In artikulären Chondrozyten wird die terminale Differenzierung blockiert. Die Zellen treten in einen proliferativen Arrest ein und zeigen im gesunden Gelenkknorpel keine weiteren Mitosen und damit keine weitere Zellteilung (Kuettner 1992; Muir 1995). Unter normalen Umständen ist der hyaline Knorpel, gemessen an Auf- und Abbauraten der Matrix, ein stoffwechselträges Gewebe. Dieses Bild ist allerdings dem Zell-Matrixverhältnis geschuldet, denn die einzelnen Chondrozyten sind, unter anderem gemessen an der Glykolyserate, stoffwechselaktive Zellen (Buckwalter und Mankin 1998; Archer und Francis-West 2003). Für den Erhalt des chondrozytären Phänotyps im Gelenkknorpel sind mehrere entscheidende Faktoren bekannt. Große Bedeutung haben die EZM, mechanische Stimuli und diffundierende Signalmoleküle wie Wachstumsfaktoren und Zytokine (Buckwalter und Mankin 1998; Van der Kraan et al. 2002). Zell-Matrix-Interaktionen vermitteln mechanische Einflüsse und geben den Chondrozyten Rückmeldung über den Zustand des Gesamtkonstruktes der Knorpel-EZM sowie seiner einzelnen Matrixmoleküle.

Die zentrale Rolle der Chondrozyten als einzigem residenten Zelltyp in dem besonderen Gewebe des hyalinen Gelenkknorpels erklärt seit je her ihre grosse Bedeutung in pathologischen Prozessen der OA und deren Erforschung (Archer und Francis-West 2003; Horton et al. 2006; Van der Kraan 2012).

\subsection{Der Gelenkknorpel im Prozess der Osteoarthrose}

\subsubsection{Die Pathogenese der Osteoarthrose}

Die Pathogenese der OA ist bis heute nicht vollständig aufgeklärt. Sie stellt ein komplexes Zusammenspiel aus metabolischen, biochemischen und biomechanischen sowie Umgebungsfaktoren dar (Goldring und Goldring 2006; Umlauf et al. 2010; Van der Kraan 2012). Sie ist keine klassische inflammatorische Erkrankung, aber zeigt Zeichen und Symptome entzündlicher Reaktionen (Goldring und Goldring 2007, Aigner et al. 2007).

Initiale molekulare Schädigungen und Veränderungen der Matrixbestandteile werden gefolgt von Schäden der Integrität des Netzwerkes der EZM auf makromolekularer Ebene. Primär sind die Proteoglykane, speziell Aggrecan, von den Destruktionsvorgängen betroffen, gefolgt von den Kollagenen mit ihrem Hauptvertreter Kollagen Typ II (Von der 
Mark und Glückert 1990; Dijkgraaf et al. 1995, Sandell 2007). Die biomechanischen Eigenschaften des Knorpels verändern sich. Dem zunehmenden, aber weniger gebundenen Wasser in der Matrix wird bei Schädigungen des Kollagennetzwerkes ein abnehmender Widerstand entgegengebracht und der Knorpel büßt seinen hydrostatischen Druck ein (Martinek 2003; Horton et al. 2006). Schädigungen von Kollagen Typ IX, und XI sowie weiteren Komponenten, die über Quervernetzungen und matrixinternen Verknüpfungen die Stabilität des Matrixnetzwerkes gewährleisten, führen zum Verlust der Integrität des gesamten Netzwerkes der EZM auf makromolekularer Ebene (Martinek 2003).

\subsubsection{Entwicklungen der Chondrozyten und Degradation der extrazellulären Matrix in der Osteoarthrose}

Der zentrale Akteur in der OA ist der Chondrozyt, der als einziger residenter Zelltyp im gesunden hyalinen Knorpel für den geregelten Matrix-Auf- und -Abbau zuständig ist (Horton et al. 2006; Aigner et al. 2007). Fundamentaler pathogenetischer Baustein der OA ist der Verlust der Balance zwischen anabolen und katabolen Prozessen in der EZM (Horton et al. 2006). Die Chondrozyten agieren und reagieren in der OA mit Änderungen von Synthese und Degradation, Differenzierungsmuster und Phänotyp sowie der Zellzahl (Pullig et al. 2001; Aigner et al. 2007). Ihre verminderte Fähigkeit adäquat auf umgebende Stimulatoren der Matrixdegradation $\mathrm{zu}$ reagieren und die geringe Fähigkeit zu Reparaturprozessen in dem nötigen Ausmaß zeigen sich an den histologischen Veränderungen der Matrix (Pritzker et al. 2006).

Ein entscheidender kataboler Prozess im OA-Knorpel ist die gesteigerte Synthese und Aktivierung von proteolytischen Enzymen, denen im Gesunden noch Bedeutung in der Regulation des balancierten Auf- und Abbau der Matrix zukommt. Die Biosynthese der Proteinasen findet sowohl in Chondrozyten als auch in Synovialzellen statt (Pullig et al. 2001, Goldring 2012). Nahezu im gesamten osteoarthrotischen Gelenkknorpel zeigen sich vermehrte Aktivitäten von MMP, Aggrecanasen, ADAMTS, Stromelysinen und weiteren matrixdegradierenden Proteinasen (Sandell und Aigner 2001; Cawston und Wilson 2006). Für die frühe Degradation von Aggrecan in der OA zeichnen vor allem ADAMTS-4 und 5, MMP-5 und Aggrecanasen verantwortlich (Sandell 2007). An der Schädigung von Kollagenen, vor allem Typ II sind MMP, ADAMTS-5 und auch Aggrecanasen maßgeblich beteiligt. MMP-13 konnte als Hauptakteur im Kollagen Typ II Abbau charakterisiert werden (Wu et al. 2002). Des Weiteren spielen MMP eine Rolle in der Degradation von Kollagen Typ IX und cross-links des Kollagennetzwerkes (Sandell 2007). 
Für die Initiierung und Aufrechterhaltung des aktivierten Zustandes in den dysregulierten Chondrozyten und der Imbalance zwischen Degradation und Aufbau der EZM spielen proinflammatorische Cytokine eine wichtige Rolle (Benito et al. 2005; Martel-Pelletier et al. 2008). In den geschädigten und im Degradierungsprozess befindlichen Bereichen wird deutlich, dass die proinflammatorischen Cytokine IL-1, TNF- $\alpha$ an der verstärkten Enzyminduktion und -aktivierung maßgeblich beteiligt sind (Sandell und Aigner 2001; Wu et al. 2002). IL-1 und TNF- $\alpha$ sind potente Induktoren der vermehrten Expression von katabolen Genen, verstärken autokrin und parakrin ihre eigene Produktion sowie die Synthese von anderen löslichen Mediatoren wie Chemokinen und Prostaglandinen (Pullig et al. 2001; Umlauf et al. 2010).

Auch Molekülfragmente vom Knorpelabrieb und aus Prozessen der Degradation induzieren in Synovia und umliegenden Chondrozyten die weitere Synthese von Cytokinen und proteolytischen Enzymen (Von der Mark und Glückert 1990; Martinek 2003). Die katabole Situation wird zusätzlich gefördert durch die Verminderung der Synthese und Aktivität von Inhibitoren der proteolytischen Enzyme, wie die Gruppe der TIMP, innerhalb des osteoarthrotischen Umfeldes (Sandell und Aigner 2001; Pullig et al. 2001).

Die osteoarthrotischen Chondrozyten zeigen gehäuft eine hypertrophe Umdifferenzierung, die mit Kalzifizierungen in unteren Knorpelschichten und mit tidemark Vervielfachungen in Verbindung gebracht wird (Maletius und Aigner 1999; Goldring und Goldring 2007). Die Entwicklung eines dedifferenzierten, fibroblastenähnlichen Phänotypes resultiert in der Produktion von faserknorpelähnlichem Gewebe, das trotz morphologischer und auch biochemischer Ähnlichkeiten keinen funktionellen Gelenkknorpelersatz darstellen kann (Maletius und Aigner 1999; Van der Kraan 2012).

Ein weiteres Merkmal chondrozytärer Reaktionen im Verlauf der OA ist die Aufgabe ihres Teilungsstillstandes und die Initiierung folgender Proliferationen. Die entstehenden Zellklone liegen in Gruppen, umgeben von Produkten aus der gesteigerten Synthese perizellulärer Matrixbestandteile zusammen, sogenannte Cluster (Poole 1997; Lotz et al. 2010).

Am Ende der OA steht das Versagen der chondrozytären Regenerationskapazität für den hyalinen Knorpel und sein sukkzessiver Untergang. Ab einem bestimmten Grad der Knorpeldegradation kann der Chondrozyt das Konstrukt der Matrix nicht wieder herstellen (Goldring und Goldring 2007). Synthesesteigerungen, Umdifferenzierungen und das resultierende Ersatzgewebe sind genauso wie Proliferationen Zeichen für die reaktiven, ineffektiven chondrozytären Versuche, der Knorpeldegradation entgegenzuwirken. Und 
gleichzeitig Indizien für die geringe Regenerationskapazität des hyalinen Knorpels (Sandell und Aigner 2001; Umlauf et al. 2010; Diekman und Guilak 2013).

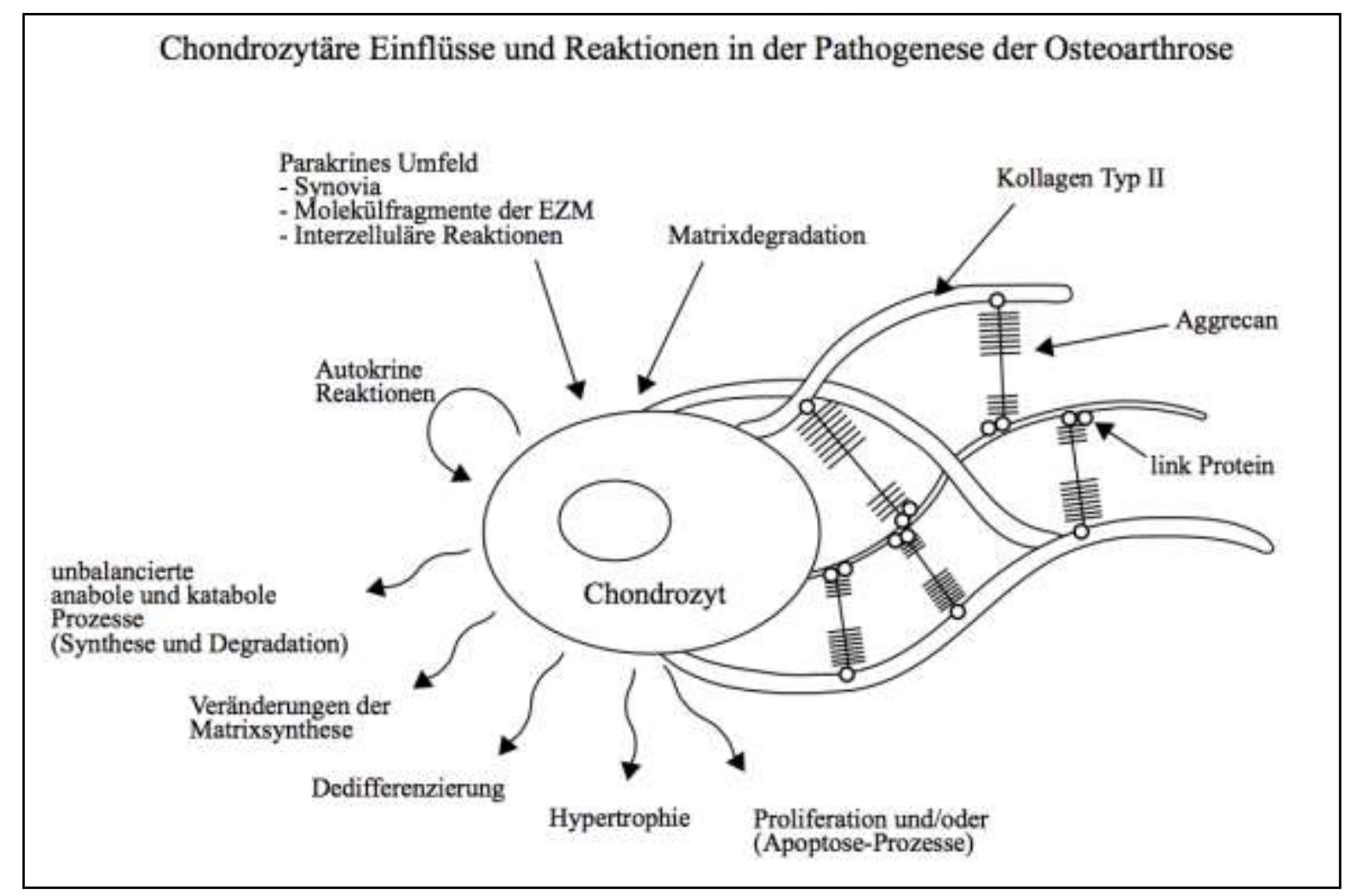

\section{Abbildung 2}

Schematische Darstellung chondrozytärer Einflüsse und Reaktionen im pathogenetischen Prozess der Osteoarthrose (modifiziert nach Aigner et al. 2007)

\subsection{Differenzierungsfähige Zellen und tissue engineering}

\subsubsection{Differenzierungsfähige Zellen aus osteoarthrotischem Gelenkknorpel - chondrogene Progenitorzellen (CPC)}

Im osteoarthrotischen Gelenkknorpel später Krankheitsstadien konnte in der AG Geweberegeneration um Prof. Dr. med. Nicolai Miosge eine neue, vorher nicht beschriebene Zellpopulation, die chondrogenen Progenitorzellen (CPC), entdeckt und isoliert werden (Koelling et al. 2009). Es handelt sich um migrationsfähige Zellen, die multipotentes Differenzierungspotential, hohe Proliferationsfähigkeit und weitere Eigenschaften zeigten, in denen sich ihr Stammzellcharakter ausdrückt.

In der Kultur von kleinen Präparaten osteoarthrotischen Gelenkknorpels migrierten die CPC aus den Gewebestückchen und Reparaturgewebe stark geschädigter Areale in späten Krankheitsstadien heraus. 
Immunzytochemisch konnte in folgenden Analysen gezeigt werden, dass die CPC Stammzelmarker, wie STRO-1 und CD29, exprimierten, anhand derer Populationen mit homogener Expression stammzellassoziierter Oberflächenmarker in der Durchflusszytometrie isoliert wurden. Im Vergleich von Genexpressions- und FACS Analysen zeigten sich CPC sowohl von Chondrozyten aus gesundem Gelenknorpel als auch von einer Mischpopulation von Knochenzellen gut zu unterscheiden (Koelling et al. 2009). Ein wichtiges Merkmal von vielen Stammzellen ist ihr multipotentes Differenzierungspotential. CPC ließen sich in vitro zu adipocytären, osteoblastären und zu chondrozytären Zellen mit dazugehörigem Genexpressions- und Matrixsynthesemuster differenzieren. Im Zuge der chondrozytären Differenzierung konnte auch für CPC die Bedeutung der beiden regulatorischen Transkriptionsfaktoren Sox9 aus der Chondrogenese und Runx2 aus der osteogenen Entwicklungskaskade untermauert werden. Die mittels viralen Vektors und Einbringen von siRNA in die Zelle durchgeführten knockdownVersuche von Sox9 und Runx2 führten zu einer vermehrten chondrogenen Entwicklung der CPC beim Ausschalten der Expression des osteogenen Transkriptionsfaktors Runx2 (Koelling et al. 2009).

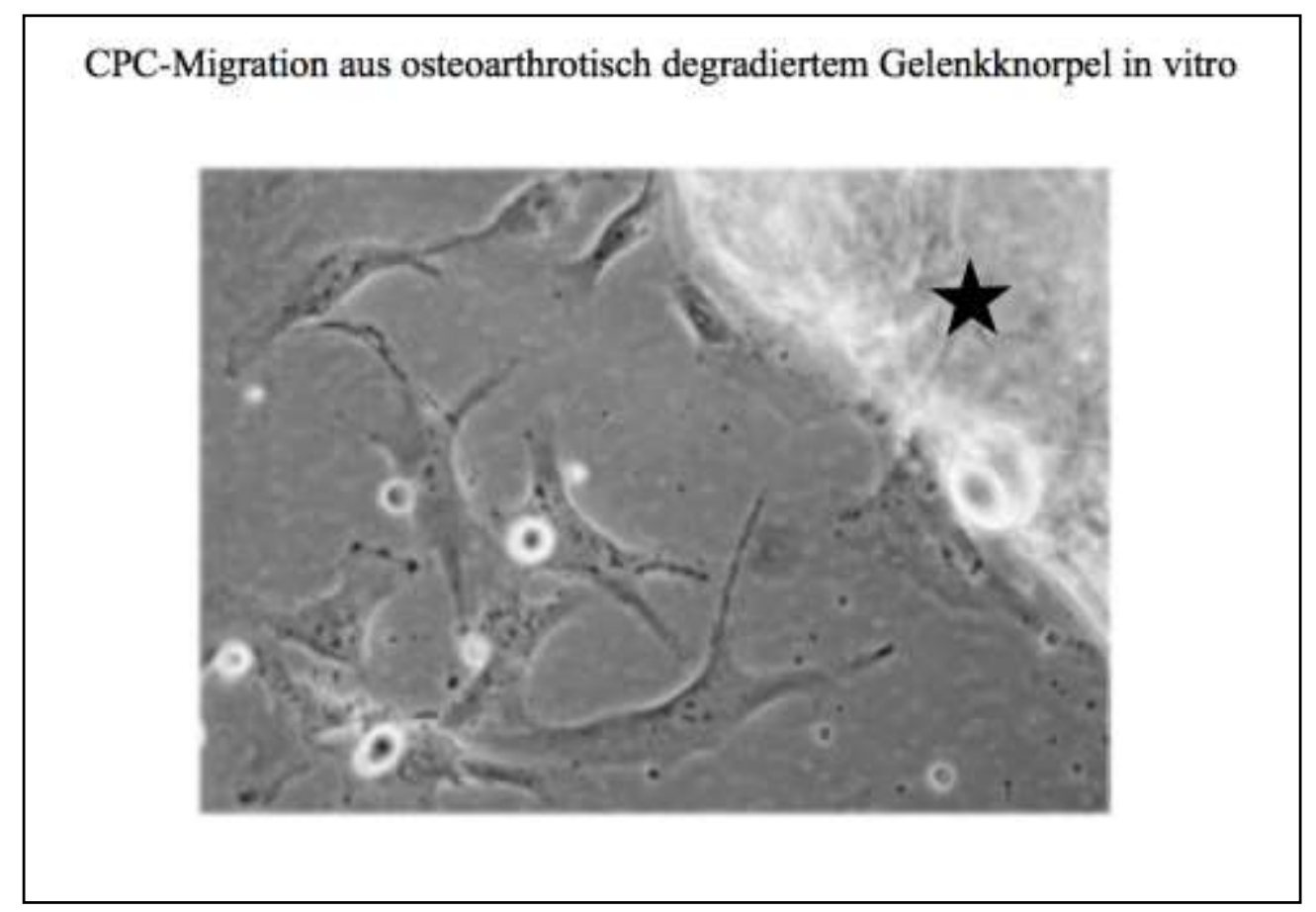

\section{Abbildung 3}

Lichtmikroskopische Beobachtung der Migration von CPC aus präparierten Gewebsstücken degradierten osteoarthrotischen Gelenkknorpels. : Präpariertes Gewebsstück von OA-Gelenkknorpel 
Die CPC zeigten in vivo innerhalb des Reparaturgewebes in späten OA Stadien wie auch in 3D-Alginatkultur in vitro, eine stabile Ausprägung ihres Phänotypes. Dessen Merkmale sind hohe Expressionswerte von Kollagen Typ I im Gegensatz zu geringen Expressionswerten von Kollagen Typ II. Die Transkriptionsfaktoren Sox9 und Runx2 wurden zeitgleich und beide auf intermediärem Niveau exprimiert (Koelling et al. 2009). Sowohl ihr Vorkommen im geschädigten Knorpel, ihre migratorischen Eigenschaften als auch ihr hohes chondrozytäres Differenzierungspotential machen diesen neuen Zelltyp für die Grundlagenforschung zur Pathogenese der OA und für die Evaluierung von zellbasierten und gentechnischen Therapieverfahren interessant (Koelling et al. 2009; Khan et al. 2009; Gerter et al. 2012).

\subsubsection{Mesenchymale Stammzellen}

Humane mesenchymale Stammzellen (MSC) sind multipotente mesodermale Zellen aus dem Verband embryologischer Ausgangszellen der Entwicklung von Bindegeweben wie Knochen Sehnen, Muskeln und Knorpel. Nicht alle dieser multipotenten Zellen entwickeln sich zu adultem spezialisierten Gewebe. Ein Teil verweilt in dem differenzierungsfähigen Stadium und besiedelt definitionsgemäß einen bestimmten Gewebebereich und bleibt dort resident, sogenannte Stammzellnische (Pittenger et al. 1999; Caplan 2007; Koelling und Miosge 2009). Im adulten Organismus bleiben MSC in ihrem Ruhezustand bestehen bis sie von unterschiedlichen Faktoren zur Migration, zu Differenzierungsvorgängen und zur Proliferation angeregt werden (Tuan et al. 2003). Für multipotente MSC gilt das Knochenmark als die wichtigste Quelle im adulten Organismus (Pittenger et al. 1999, Tuan et al. 2003). Aus den Mischpopulationen mit hämatopoetischen Vorläuferzellen können MSC-Gruppen heutzutage durch ihre charakteristische Expression von Oberflächenmarkern, wie STRO-1 und verschiedener CD-Antigene, auf der einen und dem Fehlen entsprechender Marker der hämatopoetischen Reihe auf der anderen Seite isoliert werden (Pittenger et al. 1999; Gronthos et al. 2003; Kassem und Abdallah 2008).

In zahlreichen Studien wurden MSC in verschiedene Phänotypen mit entsprechenden Genexpressions- und Synthesemustern differenziert. Sie konnten beispielsweise erfolgreich in Osteoblasten, Chondrozyten und Adipozyten differenziert werden (Johnstone et al. 1998; Barry 2003; Kassem und Abdallah 2008). Das für diese Arbeit wichtigste Potential ist die chondrozytäre Differenzierungsfähigkeit, für die Expressionsmuster und Regulatoren aus der Skelettentwicklung eine Rolle spielen (Karlsson et al. 2007; Barry und Murphy 2013). 
Das multipotente Differenzierungspotential - selbst nach mehreren Passagen in vitro und in vivo-, die hohe Proliferationskapazität und häufig auch Migrationsfähigkeit beschreiben typische Eigenschaften von Stammzellen (Pittenger et al. 1999; Prockop et al. 2001).

Diese stammzellcharakteristischen Eigenschaften der MSC sind es, die ihre große Bedeutung für die Entwicklung regenerativer Therapien von erkranktem Gewebe, insbesondere dem Gelenkknorpel, erklären (Kassem und Abdallah 2008). Neben dem Knochenmark konnten auch in anderen Geweben Zellen gefunden werden mit stammzellcharakteristischen Eigenschaften. Die Gruppen der multipotenten Zellen in den voll entwickelten mesenchymalen Geweben werden heute als Progenitorzellen bezeichnet, da davon auszugehen ist, dass sie mit dem Verlassen des Knochenmarkes und der Migration zu einem dieser Gewebe schon einen Schritt in die jeweilige Richtung einer Differenzierung eingeschlagen haben (Koelling und Miosge 2009). In Sehnen, Muskeln und Fettgewebe konnten solche mesenchymalen Progenitorzellen beschrieben werden. Und auch in adultem Knorpel zeigten sich Zellen mit typischen Charakteristiken derartiger Vorläuferzellen (Alsalameh et al. 2004; Barry und Murphy 2013).

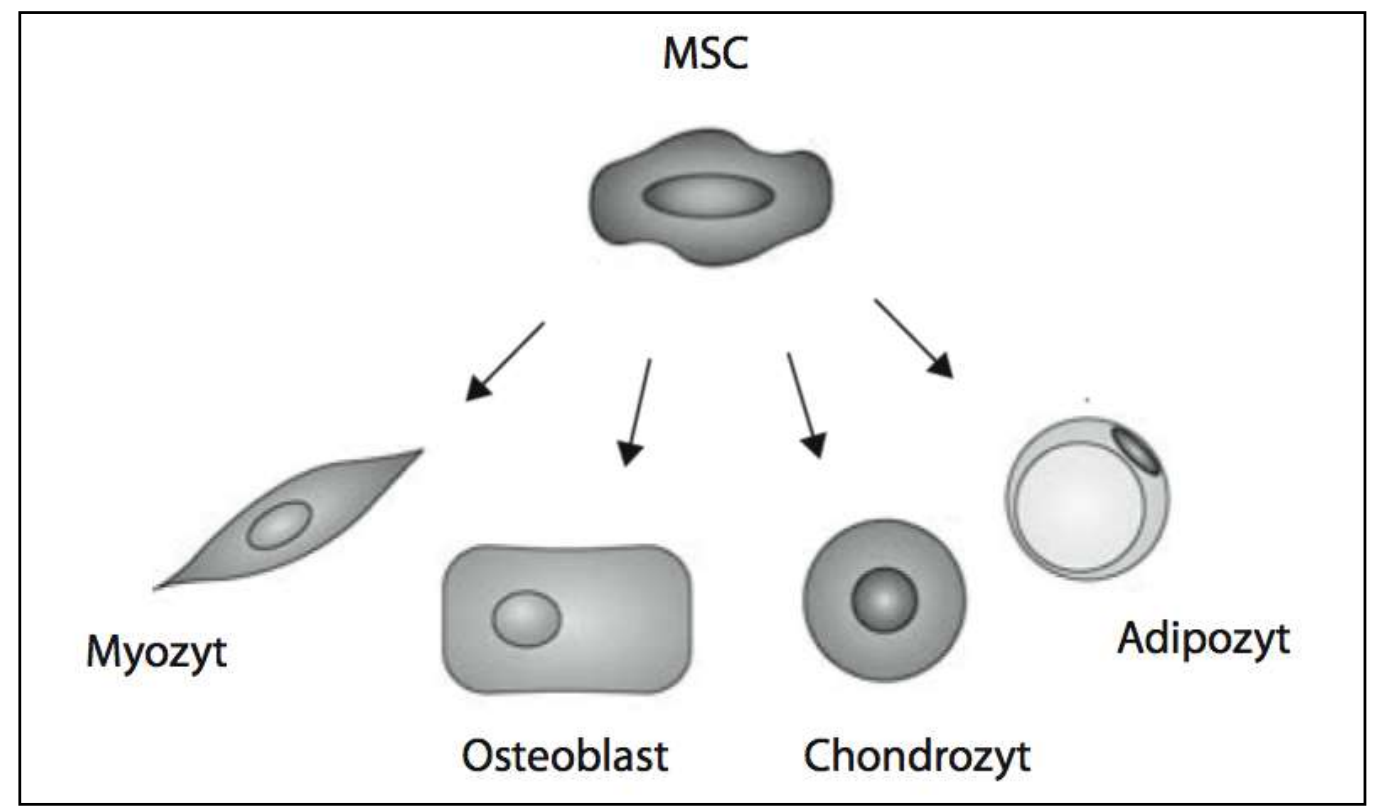

\section{Abbildung 4}

Differenzierungsmöglichkeiten der mesenchymalen Stammzellen (MSC) (modifiziert nach Takada et al. 2009).

\subsubsection{Chondrozytäre Differenzierung in vitro - Kulturprobleme und - anforderungen}

Grundlage der Entwicklung differenzierungsfähiger Zellen zu chondrozytären Phänotypen und dem Erhalt des ausdifferenzierten Phänotyps von originären Chondrozyten in vitro ist 
eine dreidimensionale Umgebung. In der Monolayerkultur können durch hohe Proliferationsraten schnell größere Zellzahlen erreicht werden, zur chondrogenen Differenzierung sind sie allerdings wenig geeignet. MSC und CPC sind erst in einer dreidimensionalen Umgebung fähig, chondrozytär $\mathrm{zu}$ differenzieren und sowohl ein knorpeltypisches Expressionsmuster als auch eine entsprechende Matrixsynthese zu zeigen (Barry 2003; Koelling et al. 2009). In dieser 3D-Umgebung unterliegen sie dem regulatorischen Einfluss trophischer Mediatoren wie TGF- $\beta$, BMP und Wnt, um die aus der Chondrogenese bekannte Entwicklungskaskade $\mathrm{zu}$ initiieren und $\mathrm{zu}$ durchlaufen (Johnstone et al. 1998; Caplan 2007). In Alginatkultur zeigten MSC einen stabilisierten rundlichen Phänotyp, in dem sie ihre chondrozytäre Differenzierung erhöhten (Tuan et al. 2003). Für CPC konnte eine chondrozytäre Differenzierung erreicht werden, allein nachdem sie in Alginatkultur und damit in einem dreidimensionalen Umfeld kultiviert wurden (Koelling et al. 2009). Unter Zusatz wichtiger parakriner Faktoren, auch hier TGFB3 und BMP-6, zeigte sich eine erhöhte mRNA-Expression von Kollagen Typ II, bei verminderten Expressionswerten für Kollagen Typ I, Runx2 und MMP-13 als Ausdruck einer verstärkten chondrogenen Entwicklung (Koelling et al. 2009; Gerter et al. 2012). Für Chondrozyten in Kultur spielt ebenfalls die dreidimensionale Umgebung die wichtigste Rolle für den Erhalt und die Stabilisierung ihres originären Phänotyps. In 3D-Kulturen wie in Alginat erhalten Chondrozyten ihren Phänotyp und zeigen charakteristische Genexpressions- und Synthesemuster inklusive der charakteristischen Produktion von Aggrecan und Kollagen Typ II (Häuselmann et al. 1992; Schulze-Tanzil et al. 2000; Tuli et al. 2003). Artikuläre Chondrozyten zeigen in der Monolayerkultur zwar auch erhöhte Proliferationsraten zur Vervielfältigung, aber sie verlieren schnell ihren originären, rundlich-ovalen Phänotyp und dedifferenzieren auch auf der Ebene von Genexpression und Synthesemuster zu einem fibroblastenähnlichem Zelltyp (Benya und Shaffer 1982; Grässel und Ahmed 2007). Dabei zeigen sich abnehmende Syntheseraten und Genexpressionen von Kollagen Typ II und Aggrecan, aber eine Zunahme derselben von Kollagen Typ I (Huch et al. 2002). In dreidimensionaler Kultur, auch in Alginat, konnten dedifferenzierte Chondrozyten wieder zurück zu ihrem originären Phänotyp finden (Benya und Shaffer 1982; Huch et al. 2002). Bezogen auf die in vivo vorliegenden Bedingungen erfüllt die Alginatkultur zudem den Anspruch fehlender direkter Zellkontakte, und es ließ sich zeigen, dass analog zu ihrem natürlichen Verhalten Chondrozyten in Alginatkultur nur gerade messbare Proliferationen zeigen (Häuselmann et al. 1992; Huch et al. 2002). 
Die 3D-Alginatkultur ist eine etablierte Methode in der Zellforschung. Sie spielt eine wichtige Rolle für Differenzierungs- und Kulturversuche mit MSC, CPC und Chondrozyten (Tuan et al. 2003; Abdallah und Kassem 2009; Koelling et al. 2009). Die Alginatkultur eignet sich besonders für Versuche, bei denen der Erhalt des chondrozytären Phänotyps wichtig ist (Huch et al. 2002). Zudem ist gilt sie in der Zellforschung als gut nutzbar für Untersuchungen von Metabolismus und Einwirkung von unterschiedlichen Mediatoren, aufgrund dessen sie für Ko-Kulturversuche empfohlen wird (Schulze et al. 2000; Huch et al. 2002). Hierfür können die Zellen aus der Alginatumgebung isoliert und biochemisch untersucht werden (Schulze et al. 2000). Die Monolayerkultur kann demnach genutzt werden, um alle drei Zelltypen aufgrund der erhöhten Proliferationsrate zu vervielfältigen und dann für Versuche und Gewebezüchtung in dreidimensionaler Kultur zu analysieren (Huch et al. 2002; Koelling et al. 2009). 


\subsection{Aufgabenstellung und Ziele dieser Arbeit}

Parakrine Einflüsse und zelluläre Interaktionen sind ein wichtiger Bestandteil aller Prozesse im osteoarthrotischen Gewebe. Sowohl für Ansätze zellbasierter Therapien des tissue engineering als auch im Verständnis pathophysiologischer Abläufe sind die in vivo vorherrschenden Bedingungen und ihrer Mediatoren von grossem wissenschaftlichen Interesse (Goldring und Goldring 2006; Onyekwelu et al. 2009, Barry und Murphy 2013). Ziel dieser Arbeit war es, vor diesem Hintergrund parakrine Einflüsse und Interaktionen in 3D-Zellkultur-Modellen zu untersuchen. Im Mittelpunkt dieser Untersuchungen standen die drei ausgewählten Zellreihen CPC, MSC und $\mathrm{gG}$ aus dem Forschungsfeld der Osteoarthrose und des Knorpel-tissue-engineering. Ihr Genexpressionsmuster wurde in den verschiedenen Versuchsbedingungen mithilfe der quantitativen Real-Time-Reverse Transkription-Polymerase-Kettenreaktion (qRT-PCR) analysiert. Mit Sox9, Aggrecan, Runx2 und Kollagen Typ I wurde gezielt die Expression von Markergenen einer chondrogenen oder osteogen-fibroblastenartigen Differenzierung untersucht. In zwei Versuchsprojekten konnten, als Bestandteile eines Gesamtumfeldes, die Auswirkungen unterschiedlich generierter parakriner Einflüsse auf das Genexpressionsmuster der Zellen charakterisiert werden.

In einem 3D-Ko-Kultur-Modell wurden jeweils isoliert vom gesamten OA-Gewebe die bidirektionalen parakrinen Interaktionen zwischen den drei Zellreihen untersucht. Hier konnten sowohl die parakrin mediierten Effekte als auch die jeweils eigenen Reaktionen der Zellen analysiert werden. In diesem Rahmen erfolgte erstmals die Beschreibung parakriner Effekte und Zell-Interaktionen von CPC.

Des Weiteren wurde der parakrine Einfluss osteoarthrotischen Gelenkknorpels auf die drei Zellreihen untersucht. Zu diesem Zweck wurde von OA-Gelenkknorpel konditioniertes Medium in einer 3D-Alginatkultur eingesetzt. Durch die vergleichende Analyse der parakrinen Mediation des Knorpels makroskopisch differenter OA-Areale sollte hiermit evaluiert werden, ob auch auf parakriner Ebene die OA als eine das gesamte Gelenk betreffende Erkrankung charakterisiert werden kann. 


\section{Material und Methoden}

\subsection{Allgemeines zur Methodik und dem Versuchsaufbau}

Im Folgenden wird ein Überblick über den grundlegenden Versuchsaufbau dargestellt.

Die drei genutzten Zellreihen wurden in Zellkulturbedingungen nach Laborstandard kultiviert. Um möglichst physiologische Bedingungen zur Untersuchung parakriner Interaktionen zu schaffen, erfolgte für alle Versuchsreihen und die Kontrollkulturen die Einbettung der Zellen in Alginat.

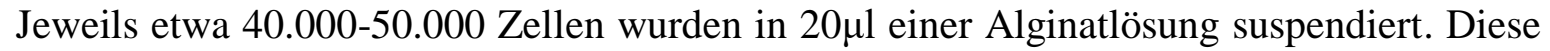
polymerisiert in $102 \mathrm{mM} \mathrm{CaCl}_{2}$ Lösung zu Kugeln aus. In der so enstandenen permeablen 3D-Umgebung wurden die Versuche durchgeführt.

In 12-well ThinCert ${ }^{\circledR}$ Multiwell Platten (Firma: Greiner BioOne GmbH, Art.-Nr.. 665.110) wurden durch entsprechende ThinCert ${ }^{\circledR}$ Cell Culture Inserts (Firma: Greiner BioOne GmbH, Art.-Nr.: 665.641) jeweils 2 Zellreihen in einer gemeinsamen 3D-KoKultur kultiviert.

Konditionierte Medien wurden durch Kultivierung von gewaschenen Gewebechips osteoarthrotischen Gelenknorpels aus zwei makroskopisch differenten Zonen hergestellt. Im Anschluss erfolgte dann die Kultivierung der einzelnen Zellreihen als Alginatkultur in diesen Medien.

Zeitgleich zu jedem Versuchsansatz wurde von den genutzten Zellreihen der 3D-KoKultur oder Alginatkulturen mit konditionierten Medien eine Alginatkultur mit Standardmedium angesetzt. Diese wurden unter identischen Kulturbedingungen zu gleichen Zeitpunkten untersucht. Hieraus entstanden somit für jede Versuchsreihe zeitgleiche, spezifische Kontrollkulturen aus gleichem Zellansatz. Ziel war es für jede Zellreihe in jedem Versuchsaufbau zu jedem Analysezeitpunkt jeweils eine eigene Kontrollkultur zu nutzen. Vor dem Hintergrund differrierender Zeitpunkte des Beginns der unterschiedlichen Versuche konnten so interne Einflussfaktoren wie Zellpassage, Kulturdauer und die Bedingungen im Versuchsablauf minimiert werden.

Zur Untersuchung kurz- und längerfristiger Ergebnisse waren die Auswertungszeitpunkte für alle Versuchsreihen auf 7 und 21 Tage festgelegt. Die Analyse erfolgte mittels quantitativer real-time RT-PCR (qRT-PCR). Hiermit kann nach Umschreiben der isolierten mRNA in cDNA über gezielte Amplifikation von Nukleotidmatrizen eine quantitative Auswertung von Transkription und Expression der untersuchten Gene erfolgen. In den Auswertungen wurden die relativen Expressionsveränderungen der 
untersuchten Gene in den Zellen unter den Versuchsbedingungen jeweils in Referenz zu den zugehörigen Kontrollkulturen analysiert und statistisch ausgewertet. Jede qRT-PCR eines Versuches wurde drei mal durchgeführt und diese Einzelergebnisse im Gesamten validiert und analysiert. Die Berechnungen der relativen Genexpressionslevel erfolgten mithilfe der PFAFFL-Ratio und wurden mit dem t-Test statistisch ausgewertet.

Das Ziel war die Darstellung der Auswirkungen isolierter parakriner Interaktionen in 3DKo-Kultur und Einflüsse aus von osteoarthrotischem Gelenkknorpel konditioniertem Medium. Analysiert wurde deren Einfluss auf das Genexpressionsmuster von Sox9, Runx2, Aggrecan und Kollagen Typ I in den 3 untersuchten Zellreihen.

Hierzu erfolgten insgesamt 576 PCR-Untersuchungen, die zusammengeführt aus jeweils 3 PCR pro Untersuchung 192 Ergebnisse zur statistischen Analyse erbrachten.

\subsection{Zellreihen und Zellkultur}

\subsubsection{Mesenchymale Stammzellen (MSC)}

Die multipotenten mesenchymalen Stammzellen wurden aus humanem Knochenmark einer 25-jährigen Spenderin isoliert. Die Isolation, Stammzellcharakterisierung und Beschreibung der Differenzierungsmöglichkeiten dieser Zellreihe erfolgte durch die AG Experimentelle Chirurgie und Regenerative Medizin um Prof. Dr. Schieker, München. (Böcker et al. 2008). Aus einer Kooperation resultierend konnten diese Zellen in den durchgeführten Versuchen genutzt werden.

\subsubsection{Chondrozyten aus gesundem Gelenkknorpel (gG)}

Die Chondrozyten aus relativ gesundem Gelenkknorpel wurden, angelehnt an die Beschreibung der Knorpelmakroskopie, als gG-Zellen charakterisiert. Dieser wurde entsprechend den Anordnungen der Ethikkomission der Medizinischen Fakultät der Universität Göttingen von einer Patientin im Rahmen einer Operation gespendet (EthikAntrag Nr.: 25/12/10). Die Zellisolierung erfolgte durch einen 4-stündigen KollagenaseVerdau von kleinen Knorpelchips, die mit einem Skalpell präpariert wurden. Im Anschluss an den Verdau der extrazellulären Knorpelmatrix wurde die Lösung durch ein $40 \mu \mathrm{m}$ Zellsieb (Firma BD Biosciences, Art.-Nr.: 352340) filtriert. Aus der gewonnenen Suspension konnten durch Zentrifugation für 10 Minuten bei $1200 \mathrm{U} / \mathrm{min}$ die Zellen separiert werden und in $75 \mathrm{~cm}^{2}$ Zellkulturflaschen (Firma: Sarstedt, Art.-Nr.: 83.1813.002) im beschriebenen Standard-Kulturmedium (s. 2.2.4) kultiviert werden. 


\subsubsection{Chondrogene Progenitorzellen (CPC)}

Chondrogene Progenitorzellen, isoliert und erstbeschrieben von der AG orale Biologie und Geweberegenration um Prof. Dr. med. N. Miosge, werden aus degradiertem osteoarthrotischem Gelenkknorpel von Patienten, bei denen eine Knie-Total-Endoprothese implantiert wurde, gewonnen. Das explantierte Tibiaplateau und die Femurkondylen wurden während der Operation in sterile Behältnisse mit PBS : DMEM-Lösung im Verhältnis 1:1 überführt und gekühlt transportiert. Im Anschluss daran wurden die Explantate unter sterilen Bedingungen mehrfach mit PBS gespült. Mit einem Skalpell erfolgte die Präparation von kleinen, einzelnen Knorpelchips (Länge und Breite 3-5mm, Dicke etwa 2mm) aus dem makroskopisch hochgradig destruierten Gelenkknorpel, getrennt vom darunter liegenden Knochen. Nach erneuter Spülung wurden die Knorpelchips in einer $75 \mathrm{~cm}^{2}$ Zellkulturflasche (Firma: Sarstedt, Art.-Nr.: 83.1813.002) im Standard-Zellkulturmedium kultiviert. Unter diesen Bedingungen migrierten die CPC aus dem Gewebe und lagerten adhärent in den Zellkulturflaschen. Nach Ausspülen der Gewebereste erfolgte anschließend die Isolierung, Charakterisierung und Kultivierung der CPC (Koelling et al. 2009).

Alle Zellreihen wurden im Rahmen ihrer Isolation und Charakterisierung zur Kultivierung mit dem Plasmid h-TERT transfeziert, welches eine langfristige Kultivierung und Nutzung ohne Verlust der Zelleigenschaften und Charakteristika ermöglicht.

\subsubsection{Zellkultivierung und Passagierung}

\subsubsection{Zellkultur}

Die im Folgenden beschriebenen Zellkulturbedingungen wurden für die genutzten Zellreihen gleich gehalten und regelmässig mikroskopisch kontrolliert.

Um genügend Zellen zur Untersuchung in den folgend beschriebenen Versuchsaufbauten $\mathrm{zu}$ generieren, wurden diese wie folgt kultiviert und passagiert.

Die Kultivierung der genutzten Zellreihen erfolgte primär als Monolayerkultur in $75 \mathrm{~cm}^{2}$ Zellkulturflaschen (Firma Sarstedt, Art.Nr.: 83.1813.002) mit Zellkulturmedium nach laboreigenem Standard, welches DMEM-Medium mit FCS und Penicillin/Streptomycin enthält. Im Zellkulturschrank wurden die Zellen bei $37^{\circ} \mathrm{C}$ und $5 \% \quad \mathrm{CO}_{2}$ bis zur lichtmikroskopisch kontrollierten Konfluenz von ca. 60-70\% kultiviert. In diesem Stadium erfolgte die enzymatische Lösung der Zellen aus der Zellkulturflasche mit Trypsin/EDTALösung. Anschließend wurden die Zellen mit PBS gewaschen, zentrifugiert, resuspendiert 
und nach Zellzahlzählung mit einer Konzentration von $4 \times 10^{3}$ Zellen/cm ${ }^{2}$ in $75 \mathrm{~cm}^{2}$ Zellkulturflaschen mit Standardmedium ausgesät.

PBS ist eine standardmäßig genutzte Substanz der Zellkultur, bei der es sich um eine isotone phosphatgepufferte Salzlösung handelt, die einen konstanten $\mathrm{pH}$ Wert von 7,4 aufweist und durch ihre Pufferfunktion bewahrt.

Die Monolayer-Zellkultur wurde jeweils fortgeführt, bis eine ausreichende Zellzahl zum Beginn eines Versuchsansatzes generiert wurden. Ein Mediumwechsel erfolgte erstmals nach 2 Tagen im weiteren Verlauf alle 3-4 Tage.

\section{$\underline{\text { Zellkulturmedium }}$}

$500 \mathrm{ml}$ DMEM (Firma: GIBCO, Art.-Nr.: 21885)

$+\quad 50 \mathrm{ml} \mathrm{10 \%} \mathrm{FCS} \mathrm{(Firma:} \mathrm{GIBCO,} \mathrm{Art.-Nr.:} \mathrm{10270-106)}$

$+5 \mathrm{ml}$ Penicillin/Streptomycin (50000 Units/50mg; PAN Biotech, Art.-Nr.: P0607100)

Dulbecco's Modified Eagle Medium (DMEM) ist ein standardisiertes ZellkulturNährmedium. Es enthält Salze, Zucker, Aminosäuren und Vitamine.

Fetales Kälberserum (FCS) wird in der Zellkultur unter anderem aufgrund seines großen Angebotes an Proteinen den Grundmedien zugesetzt. Nach Reinheitsrichtlinien wird es aus fetalem Kälberblut gewonnen.

Die antibiotische Prophylaxe in der Zellkultur erfolgte mit Penicillin und Streptomycin.

\section{$\underline{10 \times \operatorname{PBS}(\mathrm{pH} 7,4)}$}

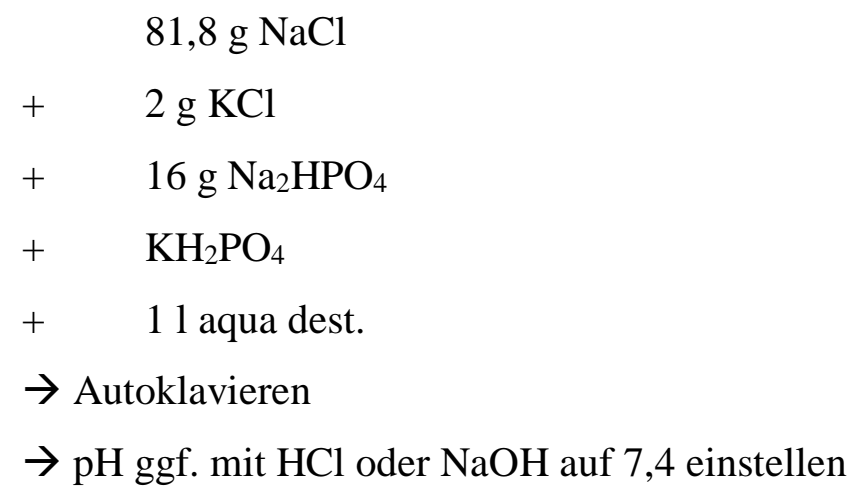

In den hier durchgeführten Untersuchungen und Präparationen wurde 1x PBS genutzt. Dazu wurde vom Hauptansatz eine Verdünnung mit Aqua dest. Im Verhältnis von 1:10 hergestellt. 


\subsubsection{Passagierung der Zellen in Kultur}

Nach Erreichen einer Zellkonfluenz von ca. 70\% wurde das Zellkulturmedium mit einer Pipette abgesaugt und die Zellen mit PBS in der Zellkulturflasche gewaschen. Anschliessend konnte durch Zugabe von $2 \mathrm{ml}$ Trypsinlösung die Lösung der adhärenten Zellen vom Boden der Zellkulturflasche erreicht werden. Trypsin ist ein Enzymgemisch dreier Peptidasen, die Adhäsionslösung der Zellen ließ sich lichtmikroskopisch verfolgen und kontrollieren. Die Einwirkzeit betrug maximal 4-5 Minuten, um zelluläre Schaden zu vermeiden. Durch zeitgerechte Zugabe von $5 \mathrm{ml}$ Zellkulturmedium wurde das Trypsin durch ein Überangebot an Substrat des FCS zeitgerecht deaktiviert. Die Zellsuspension wurde anschliessend aus der Zellkulturflasche in ein $15 \mathrm{ml}$ Röhrchen (Firma: Sarstedt, Art.-Nr.: 62.554.002) überführt und für $10 \mathrm{~min}$ bei $1200 \mathrm{U} / \mathrm{min}$ zentrifugiert. Das entstandene Zellpellet wurde nach Abpipettieren des Mediumüberstandes in $1 \mathrm{ml}$ PBS resuspendiert. Die Zellzahlbestimmung in dieser Suspension wurde mithilfe eines Cellometers AutoT4 (Firma: Nexcelom, USA) durchgeführt. Die Zellen konnten anschließend erneut in $75 \mathrm{~cm}^{2}$ Zellkulturflaschen mit einer Konzentration von $4 \times 10^{3}$ Zellen/ $\mathrm{cm}^{2}$ ausgesät und in $10 \mathrm{ml}$ Standardmedium kultiviert werden.

\section{Trypsinlösung:}

Trypsin/EDTA (Firma: PAN Biotech, Art.-Nr.: P10-024100)

$+\quad$ Autoklaviertes $1 \times$ PBS

$\rightarrow$ Verhältnis Trypsin/EDTA : PBS $=1: 9$

\subsubsection{Aufbau einer 3D-Kultur der Zellen in Alginat}

Zur Schaffung möglichst physiologischer Untersuchungsbedingungen wurden die Zellen für alle durchgeführten Versuche in Alginat eingebettet. Dadurch entsteht eine 3dimensionale Umgebung mit unbeeinträchtigten Diffusionseigenschaften für die parakrinen Interaktionen und Einflüsse.

Die Zellen wurden identisch zu oben aufgeführtem Vorgehen mit Trypsin aus den Zellkulturflaschen gelöst, zentrifugiert und in Re-Suspension gezählt (s. 2.2.4.2). Die ZielZellzahl in den polymerisierten Alginatkugeln sollte 40000-50000 Zellen pro Alginatkugel mit $20 \mu \mathrm{l}$ Volumen betragen. Abhängig von der Zellzahl wurde das Zellpellet nach erneutem Zentrifugieren in einem entsprechenden Volumen 1:1-Lösung von 2,4 \% Alginat und $0,15 \mathrm{M} \mathrm{NaCl}$ suspendiert. Mit einer feinen Pipette wurden jeweils $20 \mu \mathrm{l}$ dieser Zellsuspension in $102 \mathrm{mM} \mathrm{CaCl}_{2}$-Lösung überführt. Unter leichtem Schwenken in einem 
Kolben für maximal 10 min polymerisierten sie in eine rundliche Form zu Alginatkugeln, in denen jeweils 40000-50000 Zellen eingebettet waren.

\title{
$\underline{2,4 \% \text { Alginat }}$
}

\author{
$0,12 \mathrm{~g}$ Alginat-Pulver \\ $+\quad 5 \mathrm{ml}$ Aqua dest. \\ $\rightarrow$ im Wärmebad lösen \\ $\rightarrow$ steril filtrieren; 0,2 $\mu \mathrm{m}$ Filter (Firma: Nalgene, Art.-Nr.: 190-2520)
}

\section{$\underline{0,15 \mathrm{M} \mathrm{NaCl}}$}

$$
\begin{aligned}
& \quad 0,876 \mathrm{~g} \mathrm{NaCl} \\
& +\quad 100 \mathrm{ml} \text { Aqua dest. } \\
& \rightarrow \text { unter Rühren lösen } \\
& \rightarrow \text { steril filtrieren }
\end{aligned}
$$

$\underline{102 \mathrm{mM} \mathrm{CaCl}_{2}}$

$$
\begin{aligned}
& 1,132 \mathrm{~g} \mathrm{CaCl}_{2} \\
+\quad & 100 \mathrm{ml} \text { Aqua dest. } \\
\rightarrow & \text { unter Rühren lösen } \\
\rightarrow & \text { steril filtrieren }
\end{aligned}
$$

\subsection{Aufbau der Versuchsanordnungen}

\subsubsection{Versuchsaufbau der 3D-Ko-Kultur}

Nach Einbettung der verwendeten Zellen in Alginatkugeln wurden insgesamt 3 verschiedene 3D-Ko-Kultur-Versuchsreihen durchgeführt, so dass die parakrinen Interaktionen jeder Zellreihe mit jeder anderen untersucht werden konnten.

Nach der Polymerisierung in $\mathrm{CaCl}_{2}$ wurden die einzelnen Alginatkugeln mit einer $25 \mathrm{ml}$ Pipette aufgenommen und in eine Petrischale überführt. Dort erfolgte nach Entfernung des restlichen $\mathrm{CaCl}_{2}$ ein zweimaliges Waschen der Alginatkugeln mit Standardmedium. Genutzt wurden 12-well ThinCert ${ }^{\circledR}$ Multiwell Platten (Firma: Greiner BioOne GmbH, Art.-Nr.. 665.110) und passende ThinCert ${ }^{\circledR}$ Cell Culture Inserts (Firma: Greiner BioOne GmbH, Art.-Nr.: 665.641). Diese sterilen Zellkulturvorrichtungen ermöglichen die Kultur von 2 Zellreihen in einem gemeinsamen Medium ohne Zell-Zell-Kontakte und gewähren 
über die separierende Membran parakrine Interaktionen. Die wells haben ein Volumen von etwa $5 \mathrm{ml}$. Die Inserts sind über drei Vertiefungen in das well eingehangen und wahren damit einen festen Abstand zu well-Boden und Seitenwänden. Die Grundfläche der Inserts bildet eine transparente PET-Kapillarporenmembran mit einer Porengrösse von $0,4 \mu \mathrm{m}$. Dies gewährt einen Stoffaustausch per diffusionem auch grosser Moleküle. Eine Zellmigration über diese Membran ist aufgrund der Porengröße von 0,4 $\mu \mathrm{m}$ hingegen nicht möglich. Aufgrund dieser Eigenschaften eignet sich dieses Modell sehr gut für die Untersuchung von parakrinen Interaktionen ohne direkten Zellkontakt und somit für KoKulturversuche (siehe für weitere Produktinformationen auch: www.greinerbioone.com/de/germany/articles/catalogue/article-groups/424_1/).

Je well wurden 8 Alginatkugeln der einen Zellreihe, je Insert 8 Alginatkugeln der zweiten Zellreihe eingesetzt. Dieser Aufbau wurde mit $4 \mathrm{ml}$ Standardmedium befüllt und mit dem Deckel der well-Platte abgedeckt. Für die Untersuchungen nach 7 und nach 21 Tagen wurden die einzelnen 3D-Ko-Kulturen entsprechend 2-mal angesetzt.

Wie erwähnt wurden zu jedem 3D-Ko-Kultur-Ansatz parallel Kontrollkulturen durchgeführt. Hierzu wurden Alginatkugeln beider Zellreihen aus dem gleichen Versuchsansatz zur gleichen Zeit einer Monokultur in Standardmedium in wells der 12well Multiwell Platte zugeführt. Diese 3D-Kontroll-Kultur erfolgte ebenso in je 2-maligem Ansatz als 3D-Kontroll-Kultur zur Untersuchung nach 7 und 21 Tagen.

In allen Versuchen wurde alle 3-4 Tage ein Wechsel des Zellkulturmediums durchgeführt. 


\section{Schema: Versuchsaufbau 3D-Ko-Kultur}

Monolayerkultur

in Zellkulturflasche
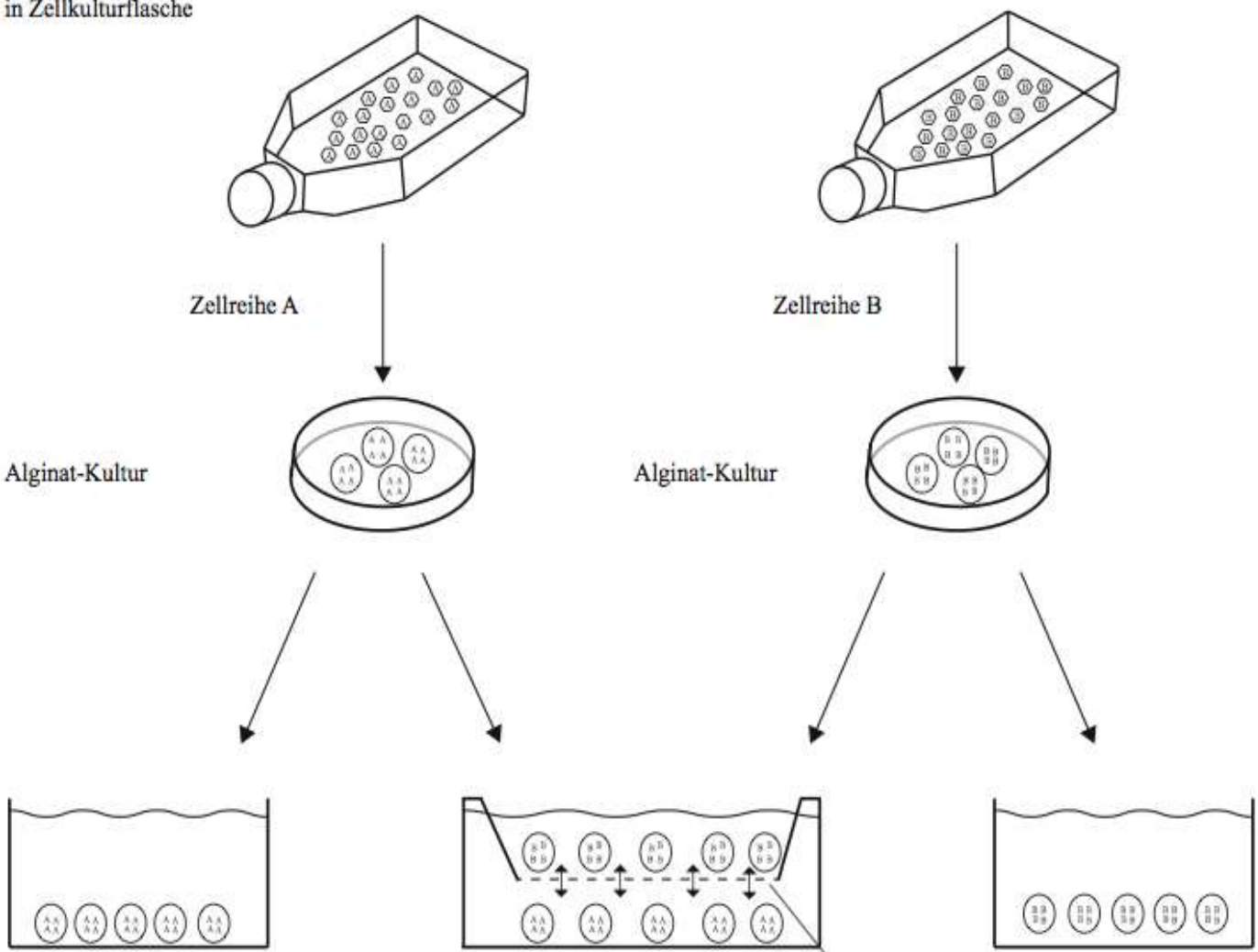

3D-Kontroll-Kultur ,A“

3D-Ko-Kultur ,A“ mit „B"

Permeable Membran (Porengröße 0,4 $\mu \mathrm{m}$ )

3D-Kontroll-Kultur ,B“

\section{Abbildung 5}

Schematische Darstellung des Versuchaufbaus der 3D-Ko-Kultur - exemplarisch unter Verwendung von zwei Zellreihen (,A“ und „B“)

\subsubsection{Versuchsaufbau der 3D-Kultur mit konditionierten Zellkulturmedien}

Das Knorpelmaterial zur Herstellung konditionierten Zellkulturmediums wurde im Rahmen des operativen Einsatzes einer totalen Knie-Endoprothese von Patienten mit späten Stadien einer Osteoarthritis gewonnen. Die Erkrankung aller Patienten entsprach den Kriterien zur Klassifikation einer Osteoarthritis des Kniegelenkes nach dem „American College of Rheumatology“ (Altman et al. 1986). Alle Patienten gaben vor der Operation nach Aufklärung über die Hintergünde ihr schriftliches Einverständnis zur wissenschaftlichen Nutzung des Gewebes. Das Gewebe stammte von 5 weiblichen und 3 männlichen Patienten. 
Nach Explantation von Femurkondylen und Tibiaplateau wurden diese in autoklavierte Behälter mit PBS : DMEM-Lösung im Verhältnis 1:1 überführt und direkt nach gekühltem Transport im Labor unter sterilen Bedingungen weiterverarbeitet. In der Sterilbank des Labors wurden die Gelenkexplantate zuerst mit PBS gespült und so von Blut und Fett befreit. Die makroskopische Einteilung des osteoarthrotischen Knorpels auf den Femurkondylen und dem Tibiaplateau erfolgte in zwei deutlich unterschiedliche Kategorien. Areale ohne sichtbare Schädigung und vom äußeren Aspekt vergleichbar mit gesundem Gelenkknorpel lagen meist fern des Hauptdefektes und wurden als G-Knorpel klassifiziert. Deutlich destruierte, aufgefaserte und aufgeweichte Knorpelareale aus dem Hauptdefekt wurden als R-Knorpel eingeteilt.

Getrennt voneinander wurden aus diesen Bereichen mit einem Skalpell kleine Knorpelchips von folgenden Maßen präpariert: Länge: 3-5 mm, Breite 3-5 mm, Dicke bis zu $2 \mathrm{~mm}$. Diese wurden erneut in Zellkulturmedium gewaschen und anschliessend 0,4 g Gewebe in einer $75 \mathrm{~cm}^{2}$ Zellkulturflasche mit $10 \mathrm{ml}$ Standardzellkulturmedium im Brutschrank bei $37^{\circ} \mathrm{C}$ und $5 \% \mathrm{CO}_{2}$ kultiviert. Nach 10 Tagen wurde das Medium mehrerer Ansätze gleich klassifizierten Knorpels durch einen sterilen Filter in $50 \mathrm{ml}$ Röhrchen (Firma: Sarstedt, Art.-Nr.. 62.547.254) überführt und bei $-80^{\circ} \mathrm{C}$ gelagert.

Für die Nutzung in den Versuchsaufbauten wurden die Medien langsam im Wasserbad aufgetaut und auf $37^{\circ} \mathrm{C}$ erwärmt.

Zur Untersuchung der Wirkung der Knorpel-generierten konditionierten Medien auf die 3 untersuchten Zellreihen wurde nach Einbettung der Zellen eine 3D-Alginatkultur durchgeführt. Je 8 Alginatkugeln mit 40000-50000 Zellen einer Zellreihe wurden in einem well der ThinCert ${ }^{\circledR}$ 12-well-Platten zum einen mit $5 \mathrm{ml} \mathrm{G}$-konditioniertem Medium und zum anderen mit $5 \mathrm{ml}$ R-konditioniertem Medium kultiviert. Auch hier erfolgte jeweils ein zweifacher Ansatz zur Analyse nach 7 und nach 21 Tagen. Ebenso erfolgte auch hier die Durchführung paralleler 3D-Alginat-Kontroll-Kulturen in Standardzellkulturmedium ohne Konditionierung in wells der ThinCert ${ }^{\circledR} 12$-well-Platten.

Sowohl in den Versuchsansätzen als auch den Kontrollen wurde das jeweils genutzte Medium alle 3-4 Tage ersetzt. 


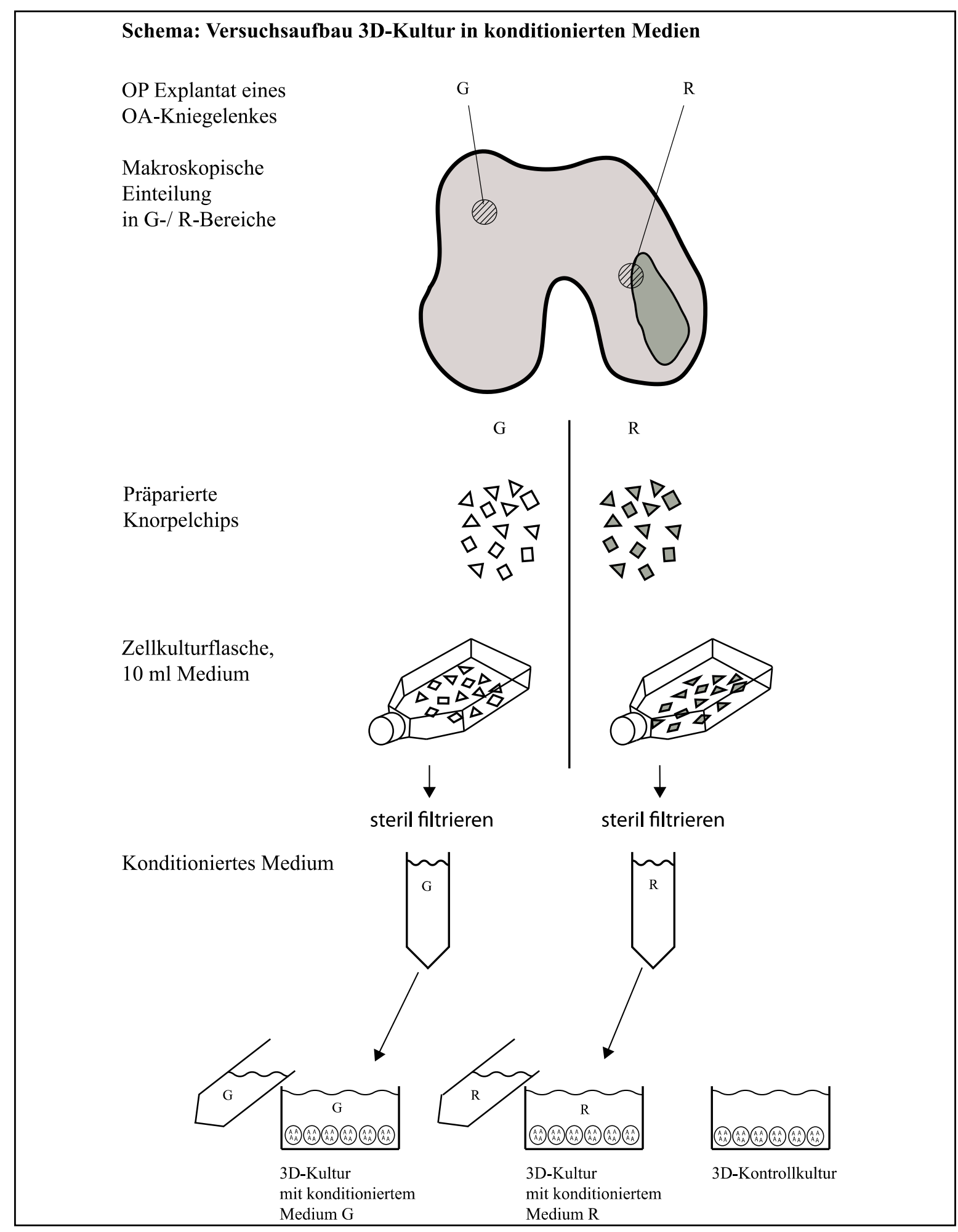

\section{Abbildung 6}

Schematische Darstellung des Versuchaufbaus der 3D-Kulturen in konditionierten Medien - exemplarisch unter Verwendung von einer Zellreihe (,A“). Darstellung der makroskopischen Einteilung in G- und RBereiche des OA-Gelenkexplantates und Herstellung der konditionierten Medien. 


\subsubsection{Kontrollkulturen}

$\mathrm{Zu}$ jedem Versuch wurde eine zeitgleiche Kontrollkultur für 7 und für 21 Tage mit Alginatkugeln des gleichen Ansatzes durchgeführt. Von den polymerisierten Alginatkugeln aus dem jeweiligen Versuchsansatz wurden auch immer Alginatkugeln in Standardzellkulturmedium, die Basis des konditionierten Mediums und das Medium der 3D-Ko-Kulturversuche, kultiviert. Die Medienwechsel werden hier im gleichen Rhythmus ausgeführt wie in den Versuchsaufbauten. In der Auswertung und Analyse konnten die Daten aus den Versuchen so immer in Relation zu jeweils eigenen Kontroll-Alginatkulturen von Zellen des gleichen Einbettungsansatzes berechnet werden.

\subsection{Isolation der RNA aus den Versuchszellen}

\subsubsection{Lyse der Alginatkugeln}

Um die Zellen zur folgenden RNA-Isolation aus dem Alginat zu lösen wurde zuerst das jeweilige Medium aus den wells pippetiert. Die Alginatkugeln mit den zu untersuchenden Zellen wurden im Anschluss mit PBS gewaschen und dann in ein $10 \mathrm{ml}$ Röhrchen überführt. Durch Zugabe von $1 \mathrm{ml}$ HEPES-EDTA-Lysepuffer löste sich das Alginat unter vorsichtigem Bewegen des Röhrchens auf und gab die Zellen frei. Es folgte das Zentrifugieren bei $1200 \mathrm{U} / \mathrm{min}$ für $10 \mathrm{~min}$, dann wurde der Überstand abpipettiert. Aus den nun am Grund des Röhrchens Pellet-artig gesammelten Zellen erfolgte die Isolation der RNA (4.2).

\section{HEPES-EDTA-Puffer $\mathrm{pH} 7,4$}

$55 \mathrm{mM}$ EDTA: 2,047 $\mathrm{g}$ EDTA in $100 \mathrm{ml}$ aqua dest.

$+10 \mathrm{mM}$ HEPES: 0,2383 g HEPES in $100 \mathrm{ml}$ aqua dest.

$\rightarrow$ Mischen im Verhältnis 1:1

$\rightarrow$ Alle Lösungen steril filtriert

\subsubsection{RNA-Isolation}

Im Anschluss an das Auflösen der Alginatkugeln folgte die RNA-Isolation aus den Zellen. Genutzt wurde für diese Isolation das RNeasy mini Kit (Firma: Qiagen, Art.-Nr.:74104). In diesem ist der Hauptanteil benötigter Materialien und Substanzen zusammengestellt und ermöglicht eine standardisierte RNA-Isolation. 
Initial wurden die Zellen in $350 \mu 1$ RLT-Puffer (Firma: Qiagen, Art.Nr.: 79216) mit 1\% $\beta$ Mercaptoethanol (Firma: Sigma-Aldrich, Art.-Nr.: 63689) in 2 Minuten bei Raumtemperatur und unter kurzem Mischen lysiert. Das Lysat wurde in einen Qiagen Shredder pippetiert, dieser für 2 min zentrifugiert und der Durchfluss wurde mit $350 \mu \mathrm{l}$ 70\% Ethanol gemischt. Die nun $700 \mu \mathrm{l}$ wurden auf die RNeasy mini column (Firma: Qiagen, Art.-Nr.: 1011708) pipettiert, für wenige Sekunden zentrifugiert und der Durchfluss anschliessend verworfen. In der RNeasy mini column bindet die gelöste RNA an eine Silicat-Membran und kann in den folgenden Schritten gereinigt werden. Zu diesem Zweck wurden zuerst $700 \mu$ RW1 Puffer (Firma: Qiagen, Art.-Nr.: 1015763) auf die Säule pippetiert, dann 20 Sekunden zentrifugiert und der Durchfluss verworfen. Das gleiche Prozedere wurde nun zweimalig mit

$500 \mu 1$ RPE-Puffer (Firma: Qiagen, Art.-Nr.: 1018013) durchgeführt, der Durchfluss jeweils verworfen. Die mini column wurde anschliessend in ein neues Sammelröhrchen gesetzt und für 1 Minute trocken zentrifugiert. Dann wurde die mini column in ein 1,5 ml Eppendorf-Tube (Firma: Eppendorf, Art.-Nr.: 0030123328) gegeben und auf die Membran mit der gebundenen RNA wurden $30 \mu$ RNAse-freies $\mathrm{H}_{2} \mathrm{O}$ pipettiert. Dieser Ansatz wurde bei Raumtemperatur für 10 min ruhen gelassen und im Anschluss für 1 min zentrifugiert. Der Durchfluss im Eppendorf-Tube enthält nun die gereinigte und in dem RNA-freien $\mathrm{H}_{2} \mathrm{O}$ gelöste RNA.

\subsubsection{Photometrische Bestimmung der RNA-Konzentration}

Unter Verwendung des Biophotometers Nanodrop® (Firma: NanoDrop, USA) wurde spektroskopisch die RNA-Konzentration und Reinheit der jeweiligen Lysate bestimmt. In die entsprechenden Glaseinsätze wurden 1,5 $\mu$ l RNA-Lysat $+8,5 \mu 1$ RNAse freies $\mathrm{H}_{2} \mathrm{O}$ pipettiert Die photometrische Absorption bei $260 \mathrm{~nm}$ und $280 \mathrm{~nm}$ gemessen. Die Konzentration der enthaltenen RNA wird benötigt um für die folgenden PCRUntersuchungen identische Ausgangsmengen $\mathrm{zu}$ berechnen. Die Absorption wird in Absorptionseinheiten angegeben und eine Absorptionseinheit bei $260 \mathrm{~nm}$ Wellenlänge entspricht $40 \mu \mathrm{g} \mathrm{RNA} / \mathrm{ml}$. Aus dem Quotienten von Absorption bei $260 \mathrm{~nm}$ und Absorption bei $280 \mathrm{~nm}$ Wellenlänge lässt sich, gemessen an typischer und nicht verunreinigter RNA, die Reinheit der Probe ausweisen. Diese sollte zwischen 1,9 - 2,1 liegen, was im Falle aller Proben generiert werden konnte. 


\subsubsection{Reverse Transkription: Umschreiben der mRNA in cDNA}

Nach Isolation der RNA aus den Zellen der Versuchsaufbauten erfolgte zur Vorbereitung der PCR-Analyse die Transkription der mRNA in ihre cDNA. Diese DNS wird, komplementär zur jeweiligen mRNA-Matrize, durch das Enzym Reverse Transkriptase synthetisiert. Die Reverse Transkriptase ist eine RNA-abhängige DNA-Polymerase, die mithilfe von Oligo-dT-Nukleotid-Primern an die repetitiven Enden der RNA-Stränge bindet und in die entsprechende cDNA transkribiert.

Produziert wurden jeweils Aliquots mit einem Endvolumen von $200 \mu$ l.

Dazu erfolgte initial die Berechnung der einzusetzenden Volumina der isolierten mRNA, die entsprechend ihrer Konzentration benötigt wird, um eine cDNA-Menge von 200 ng und damit eine Konzentration im Aliquot von $1 \mathrm{ng} / \mu \mathrm{l} \mathrm{zu}$ erzielen. Für die Transkptionseffizienz ist von einem Reverse Transkriptase-Umsatz von mRNA zu cDNA von $1: 1$ auszugehen.

Die cDNA-Synthese erfolgte in dieser Arbeit standardisiert unter Berücksichtigung der Herstellervorgaben mit dem QuantiTect Reverse Transcription Kit (Firma: Qiagen, Art.Nr.: 205313). Die Einzelschritte des Prozederes sind im Folgenden aufgrund der zahlreichen Volumina und Mengenangaben in detaillierter Übersicht dargestellt.

1. Pipettieren des ersten Ansatzes mit gDNA wipeout buffer $(14 \mu \mathrm{l})$ :

$$
\begin{array}{ll} 
& \mathrm{X} \mu \mathrm{l}=200 \mathrm{ng} \text { mRNA (konzentrationsabhängig) } \\
+ & 2 \mu \mathrm{l} \text { gDNA wipeout buffer } \\
+\quad & \mathrm{X} \mu \mathrm{l} \text { RNase-freies } \mathrm{H}_{2} \mathrm{O} \\
\rightarrow \quad & 14 \mu \mathrm{l}
\end{array}
$$

2. Inkubation für $2 \mathrm{~min}$ bei $42^{\circ} \mathrm{C}$ zur Elimination von Anteilen genomischer DNA.

3. Pipettieren des Ansatzes für die Reverse Transkription

$$
\begin{array}{ll}
+ & 1 \mu \mathrm{l} \text { Reverse Transkriptase } \\
+ & 4 \mu \mathrm{l} \text { Quantiscript RT-Puffer } \\
+\quad 1 \mu \mathrm{l} \text { R Primer Mix } \\
+\quad 20 \mu \mathrm{l}
\end{array}
$$

4. Inkubation für $15 \mathrm{~min}$ bei $42^{\circ} \mathrm{C}$. Hier erfolgt das Umschreiben der mRNA in cDNA 
5. Inkubation für 2 min bei $95^{\circ} \mathrm{C}$ zur Inaktivierung der Reversen Transkriptase.

6. Abschliessend Pipettieren auf das Zielvolumen mit einer cDNA Konzentration von lng/ $\mu \mathrm{l}$ :

$+\quad 180 \mu \mathrm{l} \mathrm{RNase}-$ freies $\mathrm{H}_{2} \underline{\mathrm{O}}$

$\rightarrow \quad 200 \mu \mathrm{l}$

2.5 Quantitative real time Reverse Transkription-Polymerase-Kettenreaktion (qRTPCR)

\subsubsection{Funktion und Ablauf der qRT-PCR}

Die Polymerase-Ketten-Reaktion (PCR) ist ein molekularbiologisches Verfahren zur gezielten Vervielfältigung von bestimmten Nukleinsäurematrizen durch eine DNAPolymerase. In mehreren Schritten kann mithilfe dieser Technik eine quantitative Analyse der Transkription und Expression eines untersuchten Gens erfolgen. Die quantitative real time RT-PCR (qRT-PCR) ist ein zweistufiges Verfahren, in dem die beschriebene reverse Transkription der isolierten mRNA als Ausgangsprodukt die erste Stufe darstellt. Daran schließen sich die im Weiteren aufgeführten Schritte des Prozess der qRT-PCR an.

Die enzymatische Amplifikation der cDNA erfolgt in mehreren Zyklen mit einer hitzestabilen Taq-Polymerase. Zur quantitativen Analyse und Detektion erfolgt die Bindung eines interkalierenden Fluoreszenzfarbstoffes - hier SYBR-Green - an die vervielfältigten DNS-Stränge.

Der Ablauf eines PCR-Zyklus kann in drei Schritten beschrieben werden:

1. Denaturierung der doppelsträngigen DNA zu Einzelsträngen bei $95^{\circ} \mathrm{C}$

2. Anlagerung der Primer an spezifische Sequenzen der DNA (Annealing), ideale Temperatur Primer-abhängig

3. Amplifikation der DNA-Komplementärstränge im Bereich des Ziel-Genes durch die Taq-Polymerase - beginnend an den Primern - bei $72^{\circ} \mathrm{C}$

Diese Schritte werden in den hier durchgeführten Versuchen jeweils 40-mal durchlaufen. Innerhalb der Zyklen werden die DNA-Stränge im Bereich der Zielsequenz exponentiell vervielfältigt, da die jeweils synthetisierten Nukleotidstränge im folgenden Zyklus wiederum als zusätzliche Matrize dienen. An die entstehenden DNA-Stränge lagert sich in 
der Reaktion der interkalierende Fluoreszenzfarbstoffes SYBR-Green an. In den einzelnen Zyklen wird anhand der Fluoreszenz so die Menge der amplifizierten DNA in Echtzeit (real time) gemessen. Abhängig von der initial vorhandenen Anzahl der spezifischen Nukleotidsequenzen des untersuchten DNA-Abschnittes erreicht die Fluoreszenzintensität $\mathrm{zu}$ einem bestimmten Zeitpunkt einen vom Programm festgelegten Schwellenwert. Der Zyklus, bei dem dieser erreicht wird, wird als $c t$-Wert $($ cycle threshold $=$ SchwellenwertZyklus) bezeichnet. Desto früher dieser erreicht wird, desto geringer ist der $c t$-Wert. Ein niedriger $c t$-Wert steht in der quantitativen Analyse somit für eine größere Menge entsprechender cDNA, respektive mRNA, und drückt damit eine höhere Expression des untersuchten Genes in den untersuchten Zellen aus.

Abschließend wird durch schrittweises Erhitzen, beginnend bei je $1^{\circ} \mathrm{C}$ unter AnnealingTemperatur in $0,2^{\circ} \mathrm{C}$-Schritten bis auf $95^{\circ} \mathrm{C}$, eine Schmelzkurve der PCR-Produkte, ebenfalls durch Fluoreszenzmessung detektiert, erstellt. Diese ist für jede entstandene doppelsträngige DNA, determiniert durch den Primer und die entsprechend amplifizierte Sequenz, spezifisch. Je nach Bindung zwischen den Doppelsträngen der DNA denaturieren diese bei einer bestimmten Temperatur und geben dabei den gebundenen Fluoreszenzfarbstoff frei. Die Intensität der Fluoreszenz wird graphisch aufgetragen und erzeugt bei der entsprechenden Denaturierungstemperatur einen singulären spezifischen Peak. Dieser ist bei einzelnem Vorliegen ein Maß der Reinheit des PCR-Produktes und schliesst eine Verunreinigung durch andere DNA-Fragmente oder fehlerhaft synthetisierte Nukleotidstränge aus.

Die qRT-PCR wurde für jeden Versuchsansatz und die dazugehörige Kontrolle mit der entsprechenden cDNA nach folgendem Schema durchgeführt.

Der verwendete SYBR-Green Mix (Platinum SYBR Green qPCR SuperMix UDG, Firma: Invitrogen, Art.-Nr.: 11733-046) enthält neben dem mit der DNA interkalierenden SYBRGreen die thermostabile Taq-Polymerase, einen Puffer mit $\mathrm{MgCl}_{2}$ und einen dNTP-Mix (Desoxyribonukleosidtriphosphate). 
1. Erstellung des Mastermix (3-fache Menge des Ansatzes):

$$
\begin{array}{ll} 
& \mathrm{X} \mu \mathrm{l}=30 \mathrm{ng} \text { cDNA (konzentrationsabhängig) } \\
+ & 2 \mu \mathrm{l} \text { Primer (forward }+ \text { reverse) } \\
+ & 15 \mu \mathrm{l} \mathrm{SYBR-Green} \mathrm{Mix} \\
+\quad & \mathrm{X} \mu \mathrm{l} \text { Nuklease-freies } \mathrm{H}_{2} \mathrm{O} \\
\rightarrow \quad & 30 \mu \mathrm{l} \text { Mastermix }
\end{array}
$$

\section{Pipettierschema}

Der Mastermix für die zu untersuchende Probe wurde in eine 96-well-Platte (Firma: Biozym Scientific, Art.Nr.: 621835) für die qRT-PCR pipettiert. Dazu sind jeweils 3 wells mit je10 $\mu$ l pro well gefüllt worden, sog. Tripletts. Die wells wurden mit Optical Flat Caps verschlossen und für 10 Sekunden anzentrifugiert, um zu gewährleisten, dass die Probe vollständig in den unteren Anteil des wells gelangt.

Jede qRT-PCR für ein Gen in einer Probe wurde zeitlich getrennt dreimal in Tripletts

\begin{tabular}{|c|c|c|c|}
\hline Initiale Denaturierung & $3 \min$ & $95^{\circ} \mathrm{C}$ & $\begin{array}{l}1 \mathrm{x} \text { am Anfang } \\
\text { der PCR }\end{array}$ \\
\hline Denaturierung & 20 sek & $95^{\circ} \mathrm{C}$ & $\begin{array}{l}40 \times \text { (1.Teil des } \\
\text { wdh. Zyklus) }\end{array}$ \\
\hline Annealing (Anlagerung der Primer) & 20 sek & Primer-spezifisch & $\begin{array}{l}40 \times \text { (1.Teil des } \\
\text { wdh. Zyklus) }\end{array}$ \\
\hline Amplifikation/Elongation & 20 sek & $72^{\circ} \mathrm{C}$ & $\begin{array}{l}40 \mathrm{x} \text { (1.Teil des } \\
\text { wdh. Zyklus) }\end{array}$ \\
\hline Letzte Amplifikation/Elongation & $10 \min$ & $72^{\circ} \mathrm{C}$ & $\begin{array}{l}1 \mathrm{x} \text { am Ende der } \\
\text { PCR }\end{array}$ \\
\hline Schmelzkurve & $\begin{array}{l}15 \text { Sek } \\
\text { je } 8 \text { Sek }\end{array}$ & $\begin{array}{l}\text { Annealing Temp. }-1^{\circ} \mathrm{C} \\
+0,2^{\circ} \mathrm{C} \text { bis } 95^{\circ} \mathrm{C}\end{array}$ & $\begin{array}{l}1 \mathrm{x} \\
{ }^{\circ} \mathrm{C} \text {-abhängig }\end{array}$ \\
\hline
\end{tabular}
durchgeführt.

\subsubsection{PCR-Programm}

Für diese Arbeit wurden die qRT-PCR im Mastercycler ep realplex ${ }^{2}$ S (Firma: Eppendorf, Deutschland) durchgeführt. Der PCR-Ablauf wurde wie folgt programmiert: 


\subsubsection{Erstellung der Oligonukleotid-Primer}

Die Herstellung der Primersequenzen für die untersuchten Gene erfolgte in unserem Labor mithilfe der Primer3 shareware. Diese Sequenzen wurden in der Datenbank BLAST (Basic Local Alignment Search Tool) des National Center for Biotechnology (NCBI) überprüft und auf den Gehalt von Nukleotidsequenzen anderer Gene abgeglichen (http://www.ncbi.nlm.nih.gov). Nach internen Standards sollte die maximale Länge der Primer nicht über 18-22 Basen liegen. Aufgrund der Ausbildung von 3 Wasserstoffbrïcken zwischen Guanin und Cytosin sollte der Anteil dieser Basen mindestens 50\% ausmachen, um eine höhere Stabilität zu generieren. Die Gen-spezifischen Sequenzen wurden zur Synthetisierung des Primers an die Firma Operon Biotechnologie GmbH (Köln, Deutschland) übermittelt. Das Produkt wurde lyophilisiert geliefert und vor Nutzung gemäß Herstellerangaben mit Nuklease-freiem $\mathrm{H}_{2} \mathrm{O}$ resuspendiert, folgend aliquotiert und bei $-20^{\circ} \mathrm{C}$ gelagert.

\subsubsection{Gradienten-PCR und Ermittlung der Annealing-Temperatur der Primer}

Mit dem Ziel für jeden Primer die ideale Annealing Temperatur zu finden wurde eine Gradienten PCR durchgeführt. Diese beruht auf den gleichen Prinzipien der Fluoreszenzmessung im Rahmen der Schmelzkurvenanalyse. In dieser Arbeit erfolgten die diesbezüglichen PCR-Untersuchungen für die Primer an cDNA von Plazenta- und Knorpelgewebe (cDNA-Konzentration $20 \mathrm{ng} / \mu \mathrm{l}$ ) durchgeführt. In der Analyse der Schmelzkurven zeigt sich die funktionell beste Bindung des Primers an die DNA-Matrize durch den höchsten und schmalsten Peak. Dieser steht im Umkehrschluss für eine effiziente Ermöglichung der Synthese der gewählten Gen-Sequenz durch die DNAPolymerase an den gebundenen Primern. Für jeden Primer wurden die Ergebnisse der PCR-Läufe mit 8 verschiedenen Temperaturen verglichen und so die AnnealingTemperatur festgelegt.

1. Erstellen des jeweiligen Ansatzes

$$
\begin{array}{ll} 
& 0,5 \mu \mathrm{l} \text { cDNA } \\
+\quad & 2 \mu \mathrm{l} \text { Primer (for }+ \text { rev) } \\
+\quad & 5 \mu 1 \text { SYBR-Green Mix } \\
+\quad & 2,5 \text { Nuklease freies } \mathrm{H}_{2} \mathrm{O} \\
\hline \rightarrow \quad 10 \mu \mathrm{l}
\end{array}
$$




\section{PCR-Programm}

Für jeden Primer wurde für jede Annealing Temperatur einer der jeweiligen $10 \mu l-$ Ansätze in 1 well der 96-well-Platte pippetiert. Der PCR-Ablauf im Mastercycler ep realplex ${ }^{2}$ S (Firma: Eppendorf, Deutschland) war wie folgt programmiert:

\begin{tabular}{|c|c|c|c|}
\hline Initiale Denaturierung & $3 \mathrm{~min}$ & $95^{\circ} \mathrm{C}$ & $\begin{array}{l}1 \mathrm{x} \text { am Anfang } \\
\text { der PCR }\end{array}$ \\
\hline Denaturierung & 20 sek & $95^{\circ} \mathrm{C}$ & $\begin{array}{l}40 \mathrm{x} \text { (1.Teil des } \\
\text { wdh. Zyklus) }\end{array}$ \\
\hline Annealing (Anlagerung der Primer) & 20 sek & variabel & $\begin{array}{l}40 \mathrm{x} \text { (1.Teil des } \\
\text { wdh. Zyklus) }\end{array}$ \\
\hline Amplifikation/Elongation & 20 sek & $72^{\circ} \mathrm{C}$ & $\begin{array}{l}40 \mathrm{x} \text { (1.Teil des } \\
\text { wdh. Zyklus) }\end{array}$ \\
\hline Letzte Amplifikation/Elongation & $10 \min$ & $72^{\circ} \mathrm{C}$ & $\begin{array}{l}1 \mathrm{x} \text { am Ende der } \\
\text { PCR }\end{array}$ \\
\hline Schmelzkurve & $\begin{array}{l}15 \text { Sek } \\
\text { je } 8 \text { Sek }\end{array}$ & $\begin{array}{l}\text { Annealing-Temp. }-1^{\circ} \mathrm{C} \\
+0,2^{\circ} \mathrm{C} \text { bis } 95^{\circ} \mathrm{C}\end{array}$ & $\begin{array}{l}1 \mathrm{x} \\
{ }^{\circ} \mathrm{C} \text {-abhängig }\end{array}$ \\
\hline
\end{tabular}

Die Endergebnisse der Primererstellung sind mit Angabe der Annealing-Temperatur in folgender Tabelle aufgeführt.

$\begin{array}{lllll}\text { Zielgen } & \begin{array}{l}\text { Primersequenz } \\ \text { forward }\left(5^{\prime} \rightarrow 3^{\prime}\right)\end{array} & \begin{array}{l}\text { Primersequenz } \\ \text { reverse }\left(3^{\prime} \rightarrow 5^{\prime}\right)\end{array} & \begin{array}{l}\text { Länge } \\ \text { PCR- }\end{array} & \begin{array}{l}\text { Annealing- } \\ \text { Temperatur }\end{array} \\ & & & \text { Produkt } & \\ \text { Sox9 } & \text { caggctttgcgatttaagga } & \text { ccgttttaaggctcaaggtg } & 155 \mathrm{Bp} & 60^{\circ} \mathrm{C} \\ \text { Aggrecan } & \text { acagctggggacat } & \text { gtggaatgcagagg } & 181 \mathrm{Bp} & 60^{\circ} \mathrm{C} \\ \text { Runx2 } & \text { ttccagaccagcagcactc } & \text { cagcgtcaacaccatcatt } & 181 \mathrm{Bp} & 63^{\circ} \mathrm{C} \\ \text { Kollagen Typ I } & \text { ttcccccagccacaagagtc } & \text { cgtcatcgcacaacacct } & 261 \mathrm{Bp} & 61^{\circ} \mathrm{C}\end{array}$

Tabelle 1: Primerliste mit Angabe der Sequenzen und Annealing-Temperaturen;

$\mathrm{Bp}=$ Basenpaare 


\subsubsection{Sequenzierung der PCR-Produkte zur Analyse der funktionellen Spezifität}

Die unter Verwendung der Primer in der PCR entstandenen Produkte wurden durch die Sequence Laboratories Göttingen GmbH (Deutschland, Göttingen) sequenziert. In einer enzymatischen DNA-Sequenzierung (Methode nach Stanger) konnten die jeweiligen Nukleotidsequenzen ermittelt werden. Unter Nutzung der NCBI-Datenbank für Nukleotidsequenzen (http://www.ncbi.nlm.nih.gov) konnte so das PCR-Produkt jeden Primers auf Übereinstimmung mit dem Zielgen abgeglichen werden. Nach dieser Prüfung wurden die Primer für die qRT-PCR-Untersuchungen eingesetzt.

\subsection{Auswertung und statistische Analyse}

\subsubsection{Auswertung und Statistik}

Die zur statistischen Analyse erforderliche Normalisierung der Versuchsergebnisse aus der qRT-PCR erfolgte gegen die cDNA der jeweiligen Kontrolle mittels des HousekeepingGens für die entsprechende Zellreihe nach Pfaffl (2004). Die Housekeeping-Gene zeigten im Kontroll- und Versuchsansatz für die untersuchte Zellreihe jeweils unveränderte Expressionswerte in der PCR. Um die Effizienz der PCR zu bestimmen erfolgte die Auswertung einer Standardverdünnungsreihe für Housekeeping-Gene und für die ZielGene dieser Arbeit. Aus Ansätzen der jeweiligen cDNA mit einer Ausgangskonzentration von $1 \mathrm{ng} / \mu \mathrm{l}$ von 1:1, 1:10, 1:50 und 1:100 in der PCR konnte eine Standardkurve der Fluoreszenz zur Zyklenzahl bestimmt und aus der Steigung die Efiizienz ermittelt werden. Es ergab sich aus den Untersuchungen in dem Labor der AG eine gemittelte Effizienz für die PCR der Ziel-Gene von 2 und für die HK-Gene von 1,895. Mit diesen Grunddaten konnte die weitere quantitative Auswertung erfolgen. Für die PCR-Ergebnisse aller Ansätze wiesen die in der weiteren Analyse und statistischen Auswertung genutzten ctWerte eine Standardabweichung von $<0,5 c t$ auf.

Der relative Expressionsunterschied konnte aufgrund der Durchführung jeweils parallel zum Versuchsansatz angesetzter Kontrollkulturen direkt zwischen Versuchsansatz und dem jeweiligen Kontrollansatz berechnet werden. Diese Ratio ergibt sich nach Pfaffl (2004) aus folgender Formel:

$$
\text { Ratio }=\frac{E^{(\text {Zielgen }) \Delta c t \text { Kontrolle-Versuch }}}{E^{(\text {Housekeeping-Gen }) \Delta c t \text { Kontrolle-Versuch }}}
$$


Aufgrund der nahezu identischen Expression der Housekeeping-Gene beschreibt die Ratio den jeweiligen Unterschied der Expression des jeweils untersuchten Ziel-Gens zwischen Kontrolle und Versuchsansatz. Die Ratio wurde für jeden der $c t$-Werte aus den einzelnen Tripletts der jeweils 3 qRT-PCR-Ansätze für jeden Analysezeitpunkt zur zeitgleichen Kontrolle berechnet. Die einzelnen Ratio-Werte bildeten nun eine Änderung der Genexpressionshöhe ab. Eine Verringerung der Expression wird so jedoch nur im Bereich von 1 bis 0 beziffert, wobei eine Ratio von 1 keine Genexpressionsveränderung ausdrückt. eine Erhöhung kann in allen Werten über 1 abgebildet werden. Zur weiteren Auswertung und Aufhebung der Darstellungsenge wurden die binären Logarithmen der Einzelwerte gebildet.

Unter Verwendung des Programmes STATISTICA erfolgte nun die statistische Analyse der qRT-PCR-Ergebnisse. Aus den logarithmierten Einzel-Ratios wurden der Mittelwert (MW) und die dazugehörige Standardabweichung ermittelt. Mit diesen Werten konnte im t-test-Modell für jeden Versuch die statistische Signifikanz (p-Wert) der abgebildeten Genexpressionsveränderungen berechnet werden. Als Signifikanzniveau für die durchgeführten Versuche wurde vorab ein $\mathrm{p}$-Wert $<0,05$ festgelegt.

\subsubsection{Housekeeping-Gene}

Zur Bestimmung des Housekeeping-Gens zur Normalisierung in der statistischen Auswertung wurden von exemplarischen cDNA-Aliquots nach oben aufgeführtem Programm qRT-PCRs durchgeführt. Für folgende Gene war die Vorraussetzung zu unveränderter bzw. versuchsunabhängiger Expression zwischen Versuchs- und Kontrollansatz erfüllt:

$\begin{array}{ll}\text { Zellreihe } & \text { Housekeeping-Gen } \\ \text { CPC } & \alpha \text {-2-Mikroglobulin } \\ \text { MSC } & \text { Laminin A/C } \\ \text { gG } & \text { PPIA (Petidylprolylisomerase A) }\end{array}$

Tabelle 2: Housekeeping-Gene 


\section{Ergebnisse}

3.1 Reaktionen im Expressionsverhalten der gG-Zellen in 3D-Ko-Kultur mit CPC und MSC sowie im Einfluss von mit Knorpel aus OA-Defekten konditioniertem Medium

\subsubsection{Der Einfluss von CPC auf gG-Zellen in 3D-Ko-Kultur}

Die Expressionsmuster in den RT-PCR-Analysen von gG-Zellen in 3D-Ko-Kultur mit CPC zeigten Unterschiede im Vergleich der Ergebnisse nach 7 und nach 21 Tagen. In dieser Versuchsanordnung wiesen gG-Zellen nach 7 Tagen eine statistisch signifikant erhöhte mRNA-Expression der chondrogenen Marker Sox9 und Aggrecan auf $(\mathrm{p}=<0,05)$.

Hingegen wurde Kollagen I, als chondrozytärer Dedifferenzierungsmarker, nach diesem Zeitraum signifikant geringer exprimiert, als in der zugehörigen Kontrollkultur.

In allen Versuchsreihen (mit Ko-Kulturen) waren keine verwertbaren Runx2-Expressionen in gG-Zellen zu beobachten.

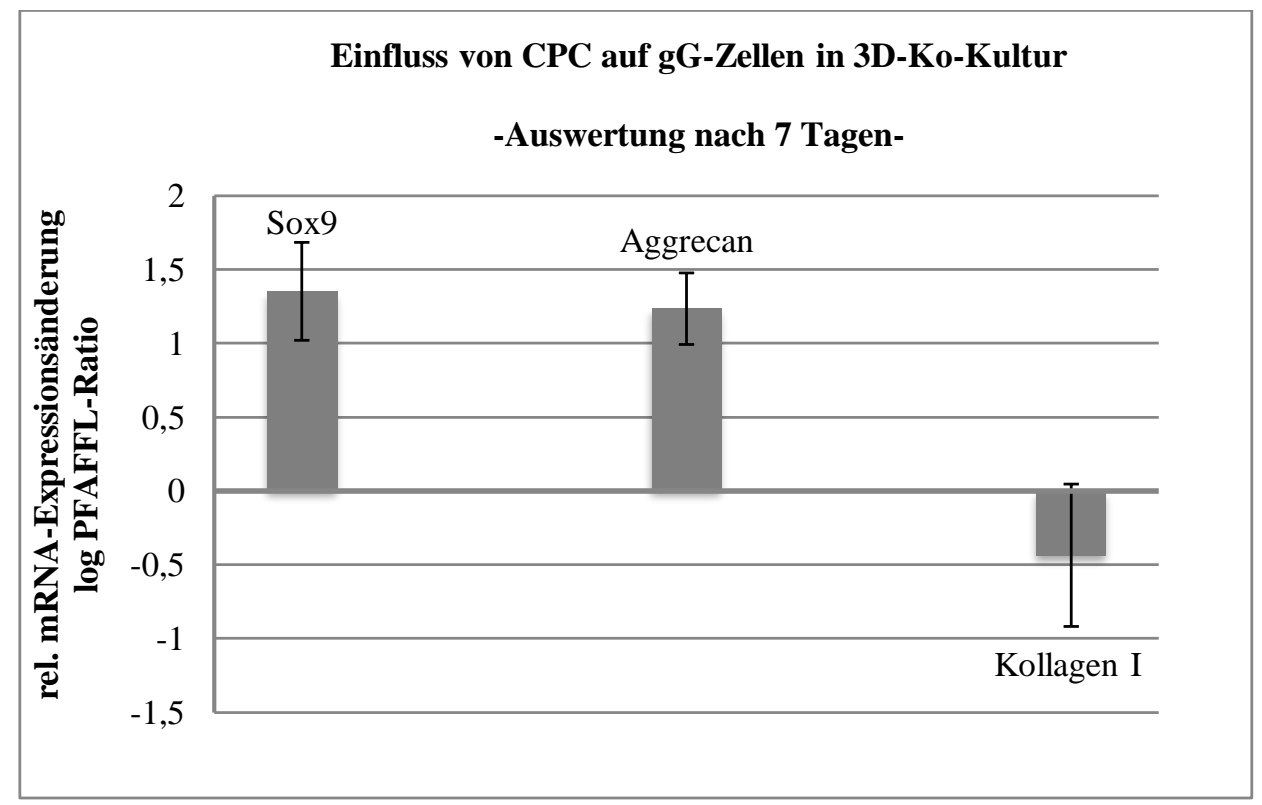

\section{Abbildung 7}

qRT-PCR-Analyse der Veränderungen des Genexpressionsverhaltens von gG-Zellen nach 7 Tagen innerhalb der 3D-Ko-Kultur mit CPC. Darstellung der relativen mRNA-Expressionsänderung als binärer Logarithmus der PFAFFL-Ratio zur jeweiligen 3D-Kontroll-Kultur. $(p=<0,05)$

Langfristig hatte die Interaktion mit CPC negativen Einfluss auf das chondrogene Expressionsmuster der gG-Zellen. In den Analysen nach einer Versuchsdauer von 21 
Tagen, zeigte sich im Gegensatz zu den kurzfristigen, eine signifikante Verminderung der mRNA-Level sowohl von Sox9 als auch von Aggrecan $(\mathrm{p}=<0,05)$. Kollagen I-mRNA war auch nach dieser Zeit weiterhin signifikant weniger stark nachzuweisen als in der Kontrolle.

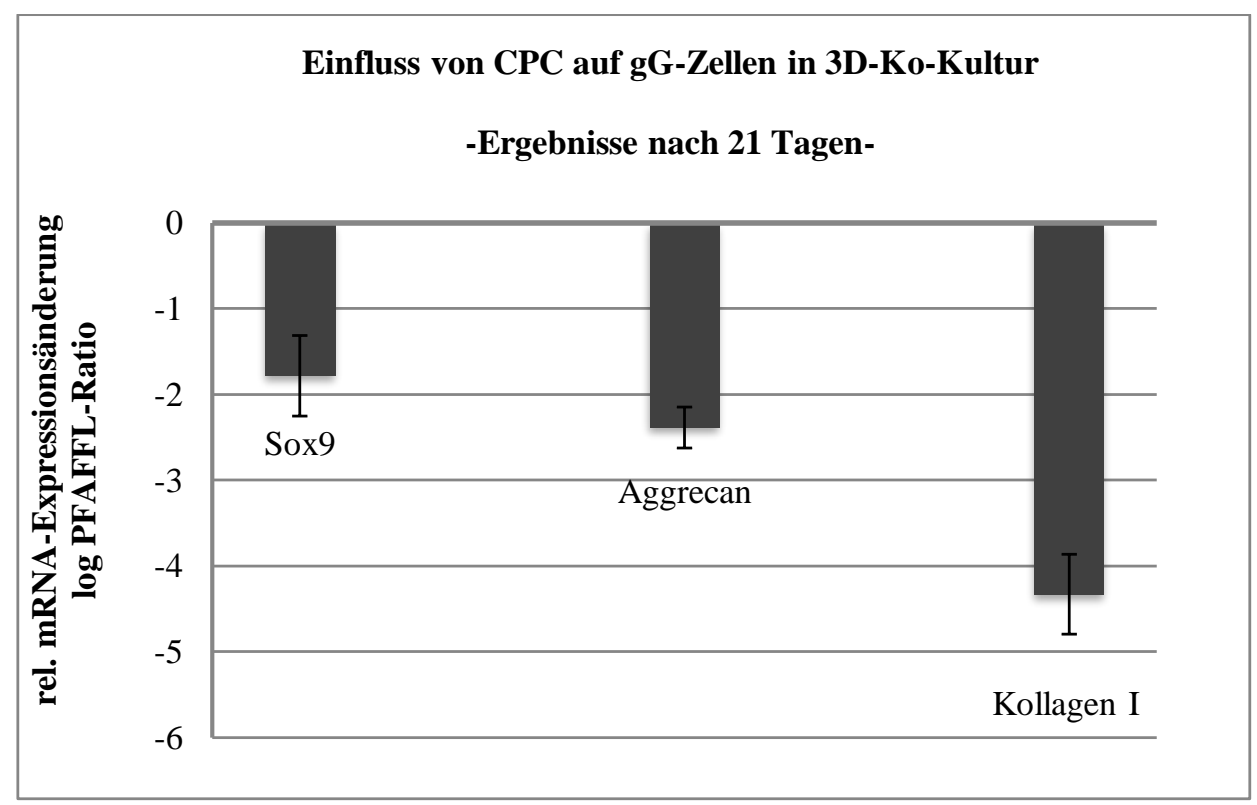

\section{Abbildung 8}

qRT-PCR-Analyse der Veränderungen des Genexpressionsverhaltens von gG-Zellen nach 21 Tagen innerhalb der 3D-Ko-Kultur mit CPC. Darstellung der relativen mRNA-Expressionsänderung als binärer Logarithmus der PFAFFL-Ratio zur jeweiligen 3D-Kontroll-Kultur. $(\mathrm{p}=<0,05)$

\subsubsection{Der Einfluss von R-konditioniertem Medium auf gG-Zellen in Alginatkultur}

Eine vergleichbare, versuchsdauerabhängige Differenz in der mRNA-Expression von den chondrogenen Differenzierungsmarkern Sox9 und Aggrecan in gG-Zellen zeigte sich genauso während der Kultur mit OA-konditioniertem Medium. Auch hier war das Sox9Expressionsniveau gegenüber der Kontrolle nach 7 Tagen signifikant erhöht und zeigte sich wiederum nach 21 Tagen signifikant vermindert. Die mRNA-Level von Aggrecan waren nach 7 Tagen nur in der Tendenz, statistisch nicht signifikant, erhöht $(p=0,26937)$. Nach 21 Tagen ließ sich dann aber auch hier im Vergleich zur Kontrolle eine signifikante Verminderung der Expression feststellen $(p=<0,05)$. Kollagen I zeigte sich nach 7 Tagen etwas stärker exprimiert als in der Kontrolle, war jedoch nach 21 Tagen ebenso reduziert wie in der 3D-Ko-Kultur mit CPC. Sowohl das von krankem Knorpel konditionierte Medium, speziell dem R-Bereich, aus dem die CPC-Zellen isoliert werden konnten, als 
auch die Interaktion mit CPC Zellen selbst, initiierten somit langfristig ein Expressionsmuster in gG-Zellen, welches auf Dedifferenzierung schließen lässt.

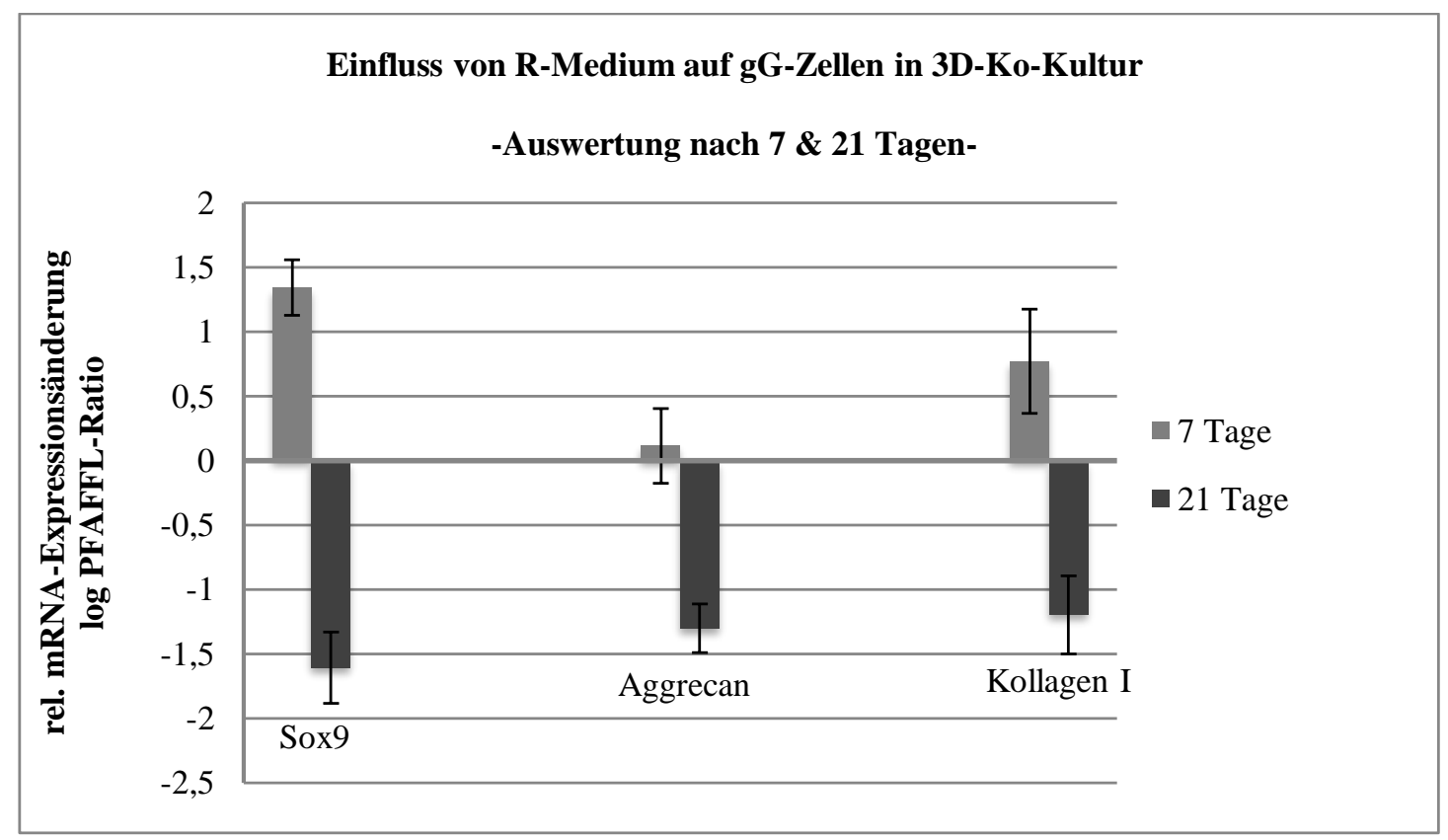

\section{Abbildung 9}

qRT-PCR-Analyse der Veränderungen des Genexpressionsverhaltens von gG-Zellen nach jeweils 7 Tagen (hell) und 21 Tagen (dunkel) innerhalb der 3D-Kultur in R-konditioniertem Medium. Darstellung der relativen mRNA Expressionsänderung als binärer Logarithmus der PFAFFL-Ratio zur jeweiligen 3DKontroll-Kultur. Sox9, Aggrecan (21 Tage), Kollagen I ( $p=<0,05)$; Aggrecan (7 Tage) $(\mathrm{p}=0,26937)$

\subsubsection{Der Einfluss von MSC auf gG-Zellen in 3D-Ko-Kultur}

Auch in den RT-PCR Ergebnissen zur Analyse der Reaktion von gG-Zellen in 3D-KoKultur mit MSC zeigte sich ein signifikanter Expressionsanstieg von Sox9 und Aggrecan nach 7 Tagen. Dem gegenüber stand eine signifikante Verminderung der Kollagen I mRNA-Werte, jeweils verglichen mit der Kontrollkultur $(\mathrm{p}=<0,05)$. Im Gegensatz zu den Entwicklungen in 3D-Ko-Kultur mit CPC und der Alginatkultur in R-konditioniertem Medium blieb hier die Herabregulation dieser chondrogenen Marker gegenüber der Kontrollwerte nach einer Versuchsdauer von 21 Tagen aus. Aggrecan wurde von gGZellen in der Interaktion mit MSC sogar auch langfristig signifikant stärker als in der Kontrolle exprimiert. Der Transkriptionsfaktor Sox9 zeigte nach 21 Tagen, verglichen mit der Kontrollkultur mRNA-Werte ohne signifikanten Unterschied $(p=0,435661)$. Unverändert blieb Kollagen I geringer exprimiert als in der Kontrolle. Diese Befunde weisen auf eine dauerhafte Verstärkung des chondrogenen Expressionsmusters hin. Ein 
solch klarer und langfristig positiver Effekt auf die Chondrogenität von gG-Zellen war einzig in dieser Versuchsanordnug nachzuweisen.

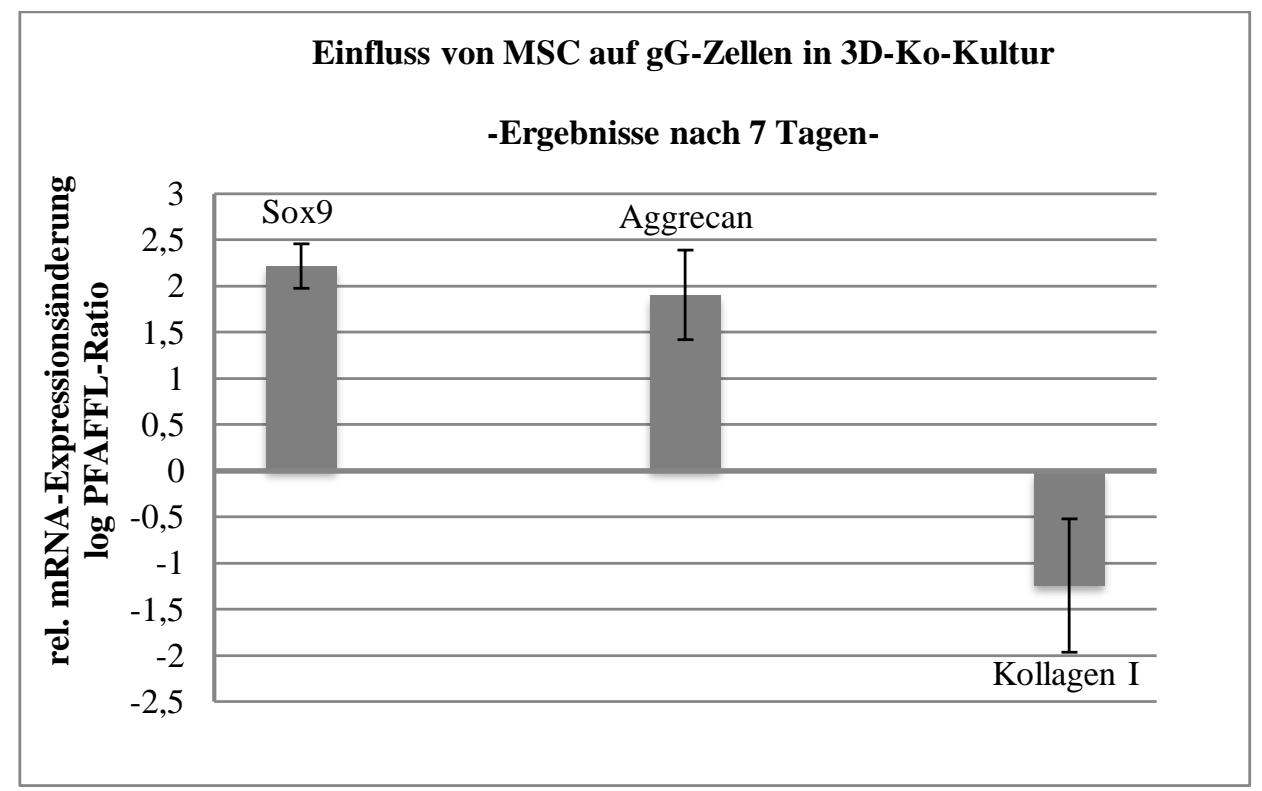

\section{Abbildung 10}

qRT-PCR-Analyse der Veränderungen des Genexpressionsverhaltens von gG-Zellen nach 7 Tagen innerhalb der 3D-Ko-Kultur mit MSC. Darstellung der relativen mRNA-Expressionsänderung als binärer Logarithmus der PFAFFL-Ratio zur jeweiligen 3D-Kontroll-Kultur. Sox9, Aggrecan, Kollagen I $(p=<0,05)$ 


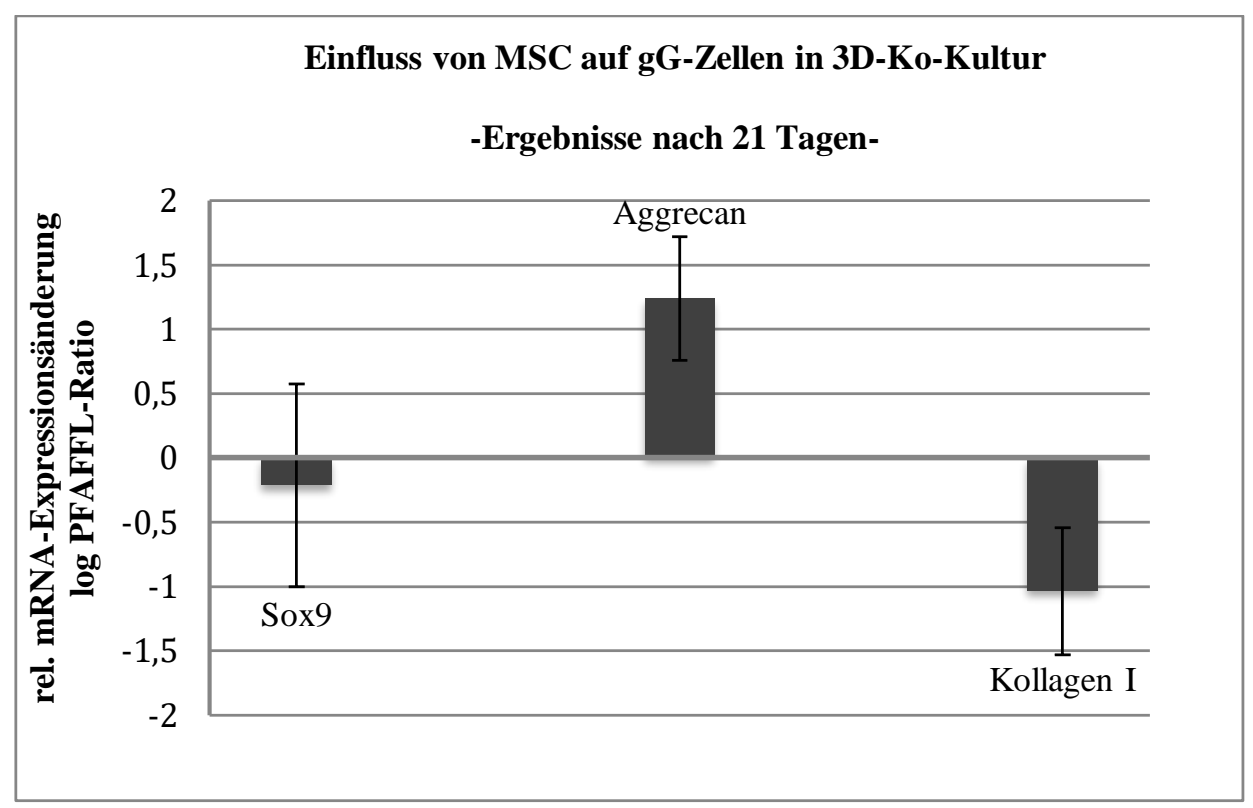

\section{Abbildung 11}

qRT-PCR-Analyse der Veränderungen des Genexpressionsverhaltens von gG-Zellen nach 21 Tagen innerhalb der 3D-Ko-Kultur mit MSC. Darstellung der relativen mRNA-Expressionsänderung als binärer Logarithmus der PFAFFL-Ratio zur jeweiligen 3D-Kontroll-Kultur. Aggrecan, Kollagen I (p=<0,05); Sox9 $(\mathrm{p}=0,435661)$

\subsection{Das Expressionsverhalten von CPC und MSC in 3D-Ko-Kultur mit gG-Zellen}

\subsubsection{Die Effekte von gG-Zellen auf das Expressionsmuster der CPC in 3D-Ko-Kultur}

CPC zeigten in dieser parakrinen Interaktion mit gG-Zellen keine Zeichen einer chondrogenen Differenzierung. Im Gegenteil wurden auch langfristig der osteogene Transkriptionsfaktor Runx2 verstärkt sowie Kollagen I stabil exprimiert.

Im Vergleich mit der Kontrolle zeigten CPC zum Zeitpunkt 7-tägiger 3D-Ko-Kultur mit gG-Zellen für Sox9 keine signifikant veränderten Expressionswerte ( $\mathrm{p}=0,397683)$. Die mRNA-Level von Runx2 und von Kollagen I waren hingegen schon nach 7 Tagen signifikant hochreguliert $(\mathrm{p}=<0,05)$. Auch in der Analyse der RT-PCR-Ergebnisse nach 21 Tagen blieb das Expressionsmuster nahezu gleich. Sox9 wurde nun geringer exprimiert als in der Kontrolle. Das mRNA-Niveau von Runx2 zeigte sich weiterhin erhöht. Keine statistisch signifikanter Unterschied fand sich in den CPC zwischen 3D-Ko-Kultur und Kontrolle bei den mRNA-Expressionswerten von Kollagen I (p=0,426708). Die Expression von Aggrecan bei Zellen der Reihe CPC war auch in diesem Versuch persistent nachweisbar, jedoch nicht in statistisch auswertbarem Maße. 
Über die gesamte Versuchsdauer waren CPC durch gG-Zellen somit zu keiner gesteigerten Expression eines chondrogenen Markers anzuregen, sondern zeigten eine stabile Expression von Runx2 und Kollagen I.

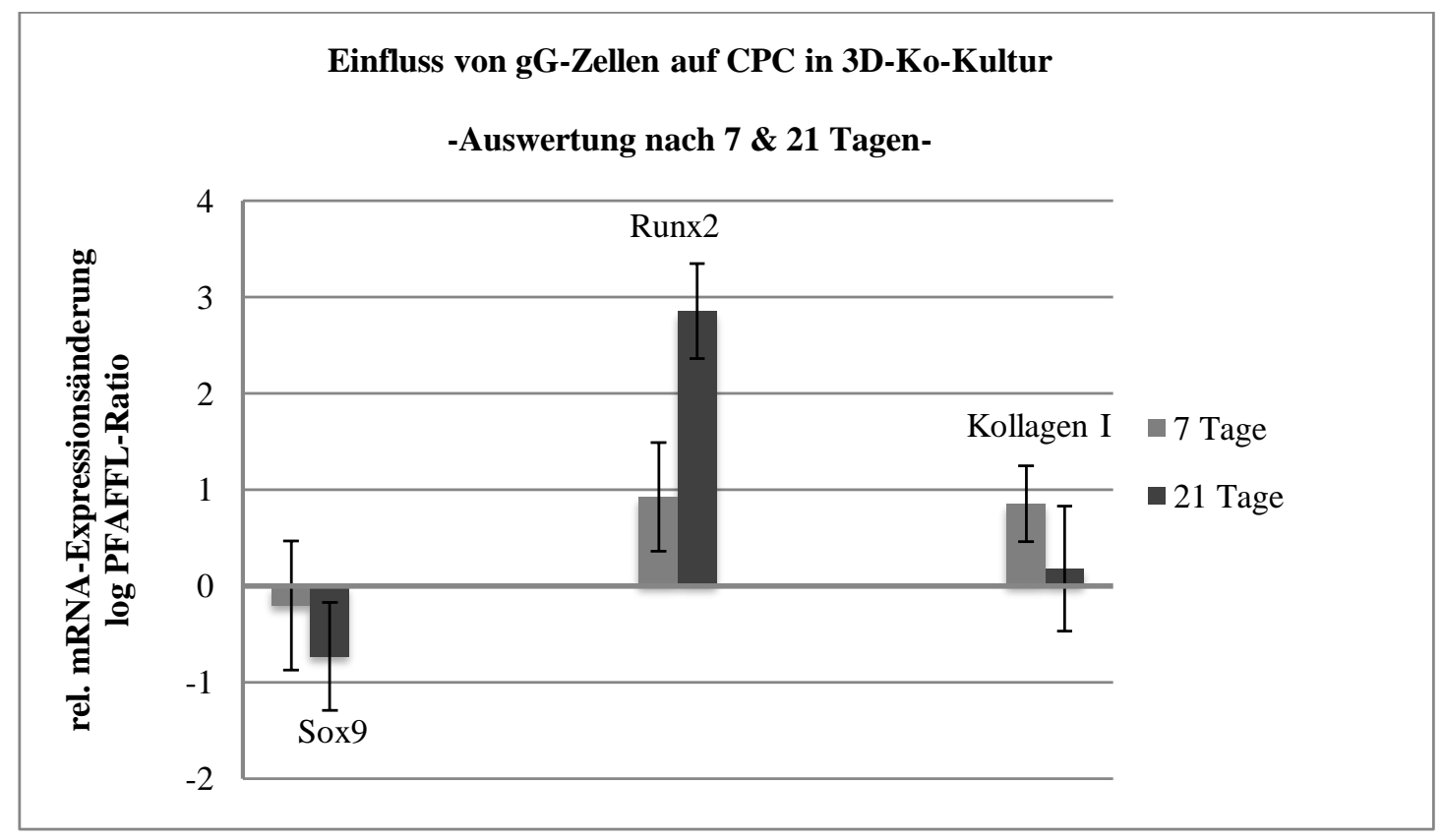

\section{Abbildung 12}

qRT-PCR-Analyse der Veränderungen des Genexpressionsverhaltens von CPC nach jeweils 7 Tagen (hell) und 21 Tagen (dunkel) innerhalb der 3D-Ko-Kultur mit gG-Zellen. Darstellung der relativen mRNAExpressionsänderung als binärer Logarithmus der PFAFFL-Ratio zur jeweiligen 3D-Kontroll-Kultur. Sox9 (21 Tage), Runx2, Kollagen I ( 7 Tage) $(\mathrm{p}=<0,05)$; Sox9 (7 Tage) $((\mathrm{p}=0,397683)$; Kollagen I (21 Tage) $(\mathrm{p}=0,426708)$

\subsubsection{Die Effekte von gG-Zellen auf das Expressionsmuster der MSC in 3D-Ko- Kultur}

Die multipotenten und differenzierungsfähigen MSC ließen sich durch die Interaktion mit gG ebenfalls nicht klar chondrogen differenzieren. Sie zeigten allerdings nach 21 Tagen eine signifikante Erhöhung aller untersuchten und verwertbar exprimierten Gene auf mRNA-Ebene. Nach einer Kulturdauer von 7 Tagen wurden in der RT-PCR signifikant geringere mRNA-Werte für Runx2 und Kollagen I gemessen als in der Kontrolle. Ebenso zeigte sich die Sox9-Expression signifikant vermindert $(p=<0,05)$. Langfristig, in der Analyse der Proben nach 21 Tagen, fielen erhöhte mRNA-Level von Sox9, Runx2 und Kollagen I gegenüber der Kontrollkultur auf. Es zeigte sich eine generelle Aktivierung der mRNA-Expression ohne eine definitive Differenzierungsrichtung. Diese Konstellation einer Hochregulation der mRNA-Level aller verwertbar exprimierten Gene in MSC ließ 
sich in keiner anderen Versuchsanordnung nachweisen. Im Vergleich dazu führten weder die 3D-Ko-Kultur mit CPC noch die Alginatkultur mit konditionierten Medien zu erhöhten mRNA-Werten eines einzigen untersuchten Markergens. Eine Expression von AggrecanmRNA bei MSC war in keiner Versuchsanordnung auszumachen.

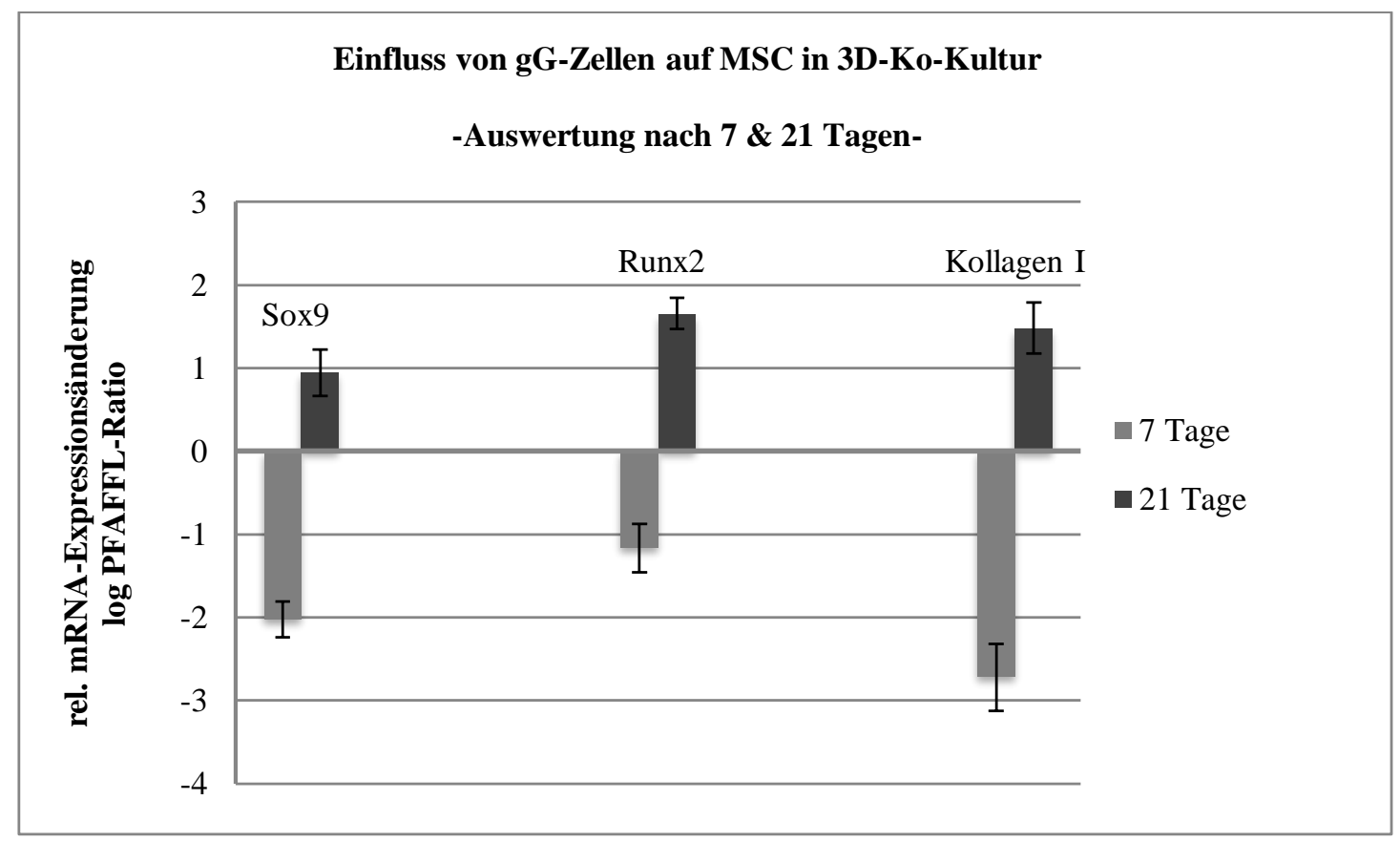

\section{Abbildung 13}

qRT-PCR-Analyse der Veränderungen des Genexpressionsverhaltens von MSC nach jeweils 7 Tagen (hell) und 21 Tagen (dunkel) innerhalb der 3D-Ko-Kultur mit gG-Zellen. Darstellung der relativen mRNAExpressionsänderung als binärer Logarithmus der PFAFFL-Ratio zur jeweiligen 3D-Kontroll-Kultur. Sox9, Runx2, Kollagen I $(\mathrm{p}=<0,05)$

\subsubsection{Zusammenfassung der parakrinen Interaktionen von gG-Zellen und MSC in gemeinsamer 3D-Ko-Kultur}

Die 3D-Ko-Kultur von MSC und gG-Zellen zeigte zusammenfassend für beide Kulturpartner in diesen Versuchen einmalige Muster der mRNA-Expression. So war es für gG-Zellen ausschließlich dieses Zusammenspiel, das zu einer langfristigen Verstärkung des chondrogenen Expressionsprofils führte. Die MSC wiesen in keinem anderen Versuchsansatz überhaupt erhöhte Expressionswerte eines untersuchten Genes auf. 


\subsection{Die Ergebnisse der gemeinsamen 3D-Ko-Kultur von CPC und MSC}

In der 3D-Ko-Kultur von CPC und MSC stehen zwei unterschiedlich, aber prinzipiell multipel differenzierungsfähige Zellen gegenüber. Keiner der beiden Zelltypen vermochte sich in dieser parakrinen Interaktion in eine definitive Richtung zu differenzieren.

\subsubsection{Das Expressionsverhalten von MSC in 3D-Ko-Kultur mit CPC}

Die CPC konnten trotz ihrer Herkunft aus zwar erkranktem, aber dennoch aus Knorpelgewebe die MSC nicht zu einer verstärkten Produktion chondrogener Markergene animieren.

Das Expressionsmuster in den MSC blieb hier über die gesamte Versuchsdauer stabil. Sowohl nach 7 Tagen als auch nach 21 Tagen zeigte sich eine signifikante Verminderung der mRNA-Produktion von Sox9, Runx2 und Kollagen I verglichen mit der Kontrollkultur $(\mathrm{p}=<0,05)$.

Eine Aggrecan-Expression von MSC wurde nicht verzeichnet.

Die Reaktion der MSC in der 3D-Ko-Kultur mit CPC hatte ein gleich gerichtetes Muster wie in der Kultur mit R-konditioniertem Medium.

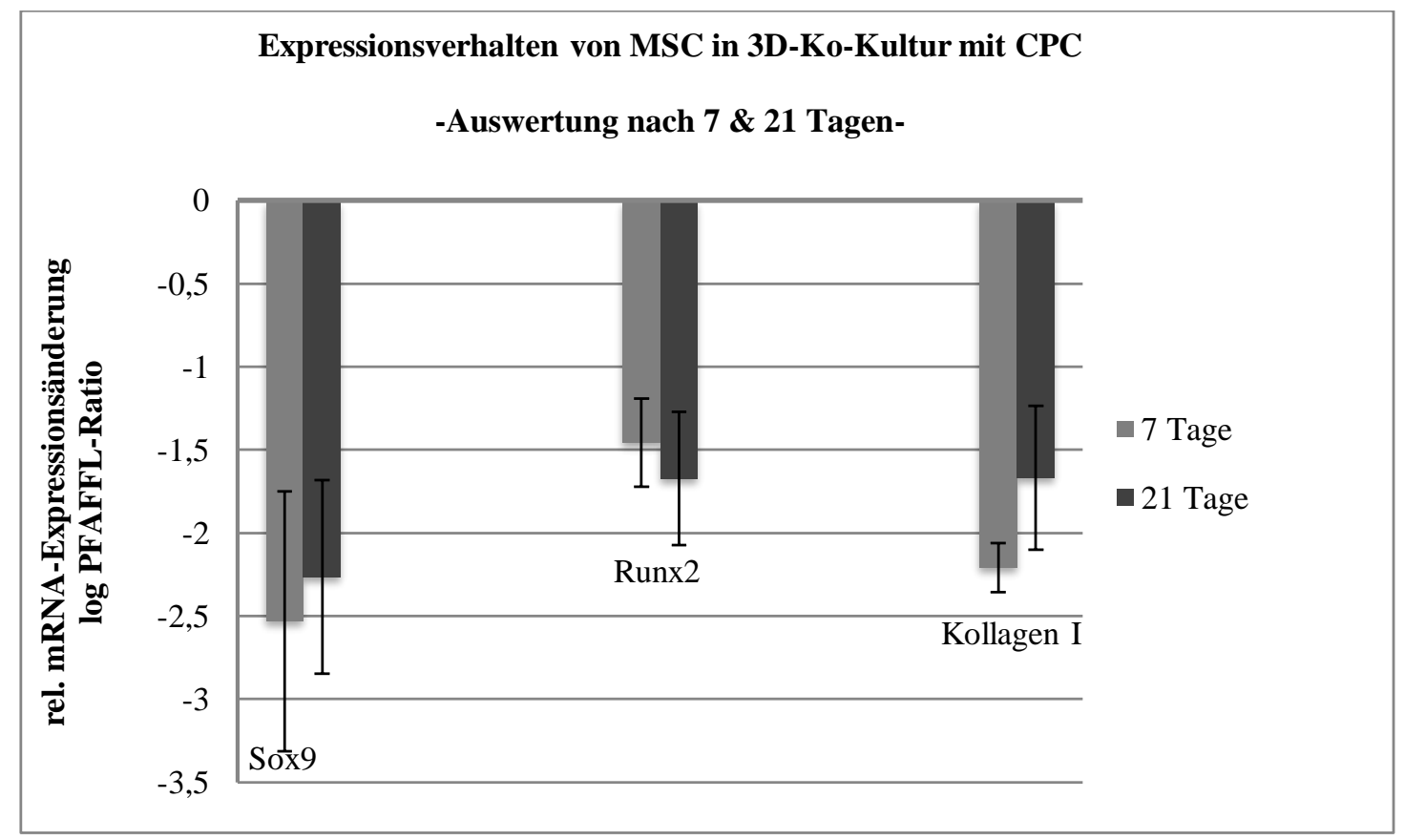

\section{Abbildung 14}

qRT-PCR-Analyse der Veränderungen des Genexpressionsverhaltens von MSC nach jeweils 7 Tagen (hell) und 21 Tagen (dunkel) innerhalb der 3D-Ko-Kultur mit CPC. Darstellung der relativen mRNAExpressionsänderung als binärer Logarithmus der PFAFFL-Ratio zur jeweiligen 3D-Kontroll-Kultur. Sox9, Runx2, Kollagen I $(\mathrm{p}=<0,05)$ 


\subsubsection{Das Expressionsverhalten von CPC in 3D-Ko-Kultur mit MSC}

Nach 7 Tagen lagen die Messwerte der Kollagen I -mRNA signifikant unter dem Niveau der Kontrolle. Die RT-PCR-Daten für Sox9 und für Aggrecan wiesen nach 7 Tagen eine signifikant erhöhte Expression beider Gene auf. Es war die einzige Situation in der 3D-KoKultur von CPC und MSC, in der sich eine erhöhte mRNA-Expression fand. Diese anfängliche Hochregulation der mRNA-Level von Runx2 und Aggrecan im Vergleich zur Kontrolle kehrte sich nach 21 Tagen um. Langfristig wurden Sox9, Aggrecan und weiterhin Kollagen I, somit alle untersuchten Gene, signifikant vermindert exprimiert $(\mathrm{p}=<0,05)$.

In Zusammenschau waren nach 21 Tagen in der 3D-Ko-Kultur von CPC und MSC bei beiden Versuchspartnern alle untersuchten und verwertbar $\mathrm{zu}$ analysierenden Gene geringer exprimiert als in ihren Kontrollen. Keine der beiden differenzierungsfähigen Zellen konnte nach 21 Tagen in Interaktion mit einem naiven oder nicht endgültig differenzierten Kulturpartner $\mathrm{zu}$ einer Aktivierung der mRNA-Expression angeregt werden. Weder die CPC noch die MSC ließen im Zusammenwirken langfristig eine Aktivierung oder definitive Differenzierungstendenz erkennen.

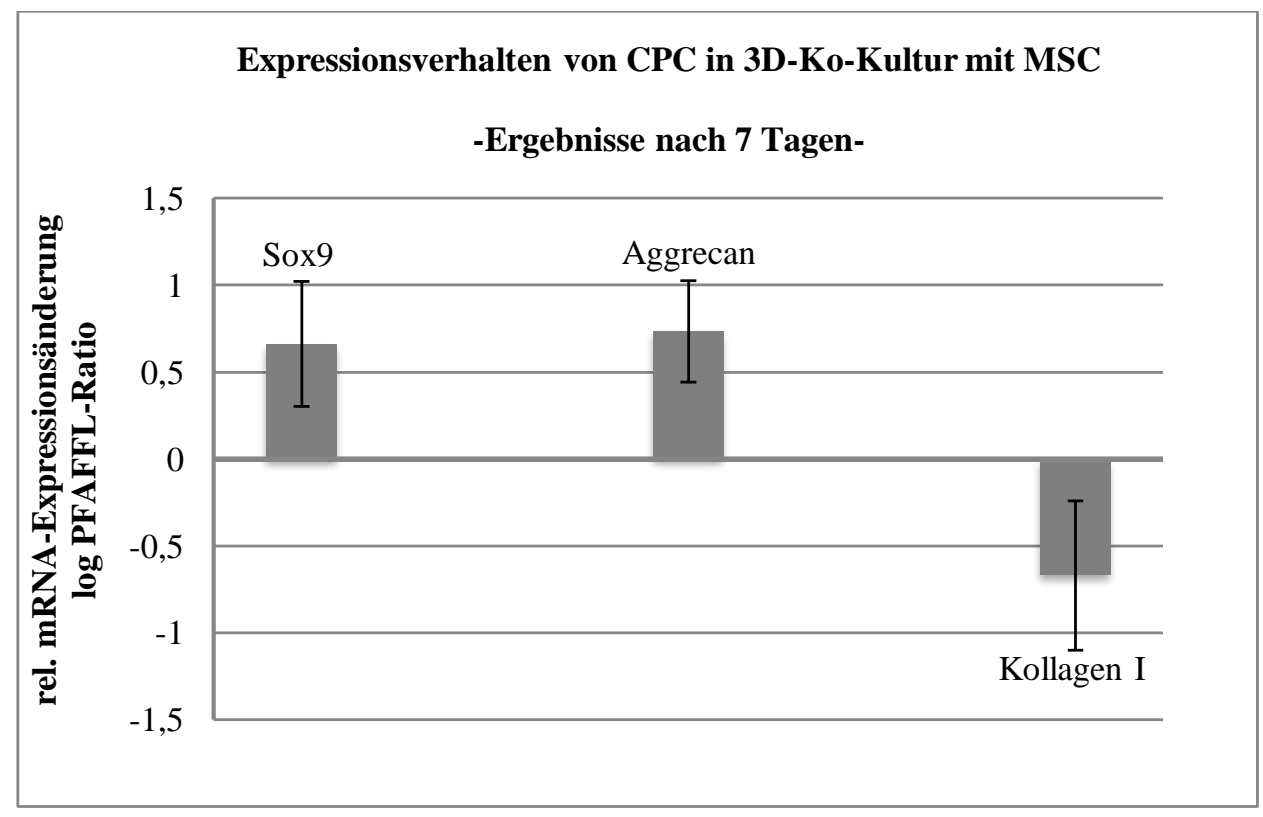

\section{Abbildung 15}

qRT-PCR-Analyse der Veränderungen des Genexpressionsverhaltens von CPC nach 7 Tagen innerhalb der 3D-Ko-Kultur mit MSC. Darstellung der relativen mRNA-Expressionsänderung als binärer Logarithmus der PFAFFL-Ratio zur jeweiligen 3D-Kontroll-Kultur. Sox9, Aggrecan, Kollagen I $(p=<0,05)$ 


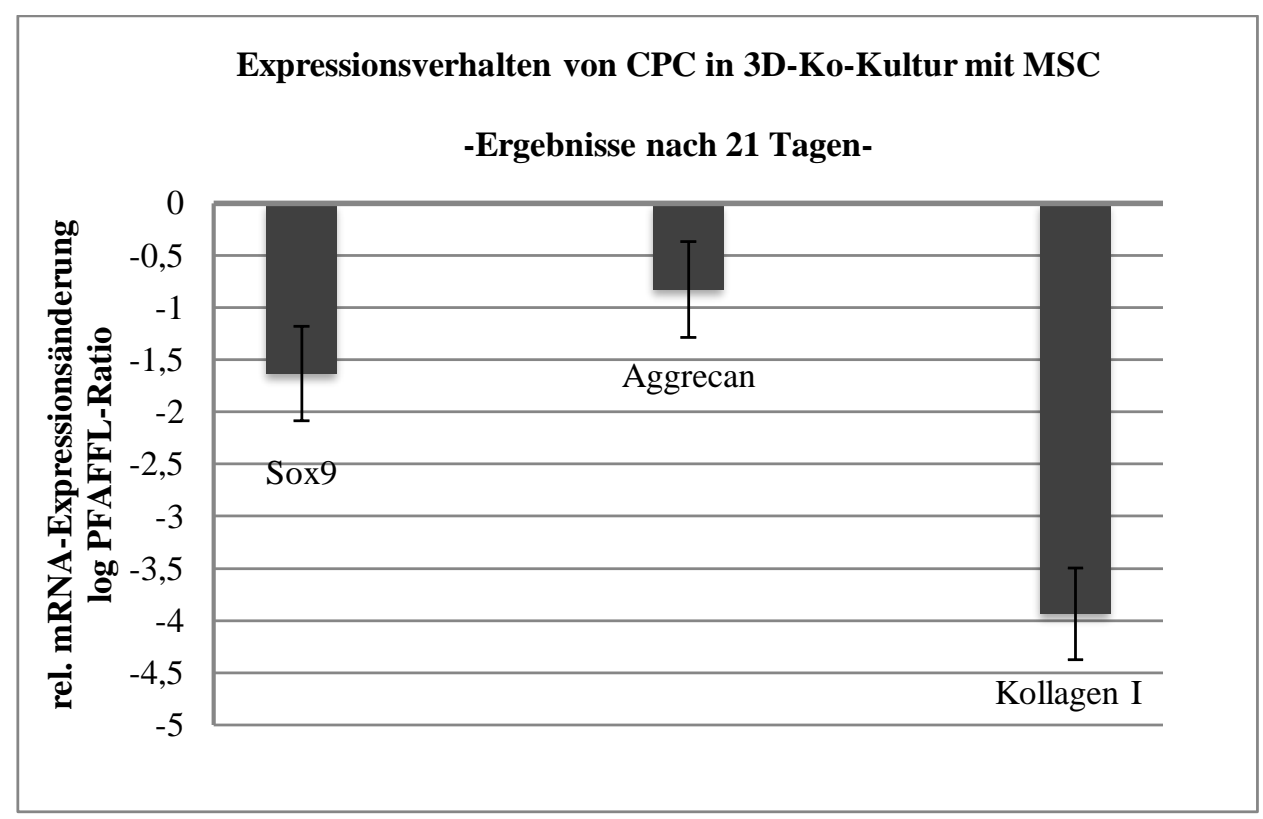

\section{Abbildung 16}

qRT-PCR-Analyse der Veränderungen des Genexpressionsverhaltens von CPC nach 21 Tagen innerhalb der 3D-Ko-Kultur mit MSC. Darstellung der relativen mRNA-Expressionsänderung als binärer Logarithmus der PFAFFL-Ratio zur jeweiligen 3D-Kontroll-Kultur. Sox9, Aggrecan, Kollagen I $(p=<0,05)$

\subsection{Konditioniertes Medium aus G- und R- Bereichen osteoarthrotischen} Gelenkknorpels - Einfluss auf das Expressionsverhalten von CPC, gG-Zellen und MSC in Alginatkultur

Die Ergebnisse werden in Bezug auf die unterschiedlichen Auswirkungen der Konditionierung des Mediums mit Knorpel aus G- oder R- klassifizierten OAGelenkknorpelbereichen dargestellt. $\mathrm{R}$ ist die Klassifikation für den Bereich makroskopisch erkennbarer, weicher und aufgefaserter Hauptläsionen innerhalb der Gelenkexplantate, die, während einer Totalendoprothesenimplantation bei OA-Patienten, aus erkrankten Kniegelenken entfernt wurden. Mit G werden die Bezirke des Knorpels bezeichnet, die den makroskopischen Vorstellungen von gesundem hyalinen Knorpel entsprechen und den augenscheinlich unveränderten Außenbereichen der Explantate entstammen.

In den Reaktionen der Versuchszellen auf die konditionierten Medien waren nur geringe Unterschiede zwischen den Kulturen in R-Medium und G-Medium zu finden. Sowohl MSC als auch gG-Zellen zeigten, jeweils verglichen mit ihrer dazugehörigen Kontrollkultur, in beiden Versuchsansätzen nahezu gleiche Expressionsmuster. Bei den CPC waren geringe Unterschiede zu finden, ohne dass jedoch langfristig Gegensätze in den Reaktionen auf R- und G-konditioniertes Medium festzustellen sind. 


\subsubsection{Die Wirkung R- und G- konditionierter Medien auf das Expressionsverhalten von MSC}

MSC reagierten auf die konditionierten Kulturmedien von krankem Gelenkknorpel zu beiden Analysezeitpunkten mit einer Verminderung der Expression aller verwertbar exprimierten Gene.

Vergleicht man die mRNA-Level in den MSC aus der Kultur in konditioniertem Medium mit ihrer jeweiligen Kontrollkultur, zeigte sich nach 7 und nach 21 Tagen eine signifikante Herabregulation der Genexpression von sox9, Runx2 und KollagenI. Diese Reaktion konnte sowohl in G-Medium als auch in R-Medium festgestellt werden $(p=<0,05)$. Eine Ausnahme in der statistischen Signifikanz stellt die nur tendenziell sichtbare Verringerung der Sox9-Expression nach 21 Tagen in R-Medium dar ( $\mathrm{p}=0$,459886). Somit war in den Expressionsmustern der MSC nach 7 und nach 21 Tagen kein unterschiedlicher Effekt bezogen auf die Makroskopie des konditionierenden Gewebes zu finden. Aggrecan wurde von MSC auch in diesen Versuchsansätzen nicht exprimiert.

\subsubsection{Die Wirkung R- und G- konditionierter Medien auf das Expressionsverhalten von gG-Zellen}

Die Untersuchungsergebnisse von gG-Zellen in der Kultur mit den konditionierten Medien zeigten ein etwas differenzierteres Bild. Im Endeffekt konnte aber auch hier beobachtet werden, dass G- und R-konditioniertes Medium langfristig die gleiche zelluläre Reaktion auf mRNA-Ebene bedingen. In der RT-PCR Analyse nach 7 Tagen waren sowohl in Kultur mit R- als auch mit G-konditioniertem Medium leicht erhöhte Expressionswerte von Kollagen I messbar. Die mRNA-Level von Sox9 zeigten sich, gegenüber der Kontrolle, in G-Medium statistisch unverändert $(\mathrm{p}=0,417121)$ und in R-Medium signifikant erhöht $(\mathrm{p}=<0,05)$. Aggrecan wurde von gG-Zellen in der Kultur mit Gkonditioniertem Medium signifikant vermindert exprimiert $(\mathrm{p}=<0,05)$ und zeigte sich bei R-konditionierter Kultur in kontrollgleicher mRNA-Höhe ( $\mathrm{p}=0$,269371). Runx2 wurde von gG-Zellen auch in diesem Versuch nach 7 Tagen nicht verwertbar exprimiert. Nach der anfänglich uncharakteristischen Reaktion ließen sich nach 21 Tagen für beide konditionierten Medien gleiche Einflüsse auf das Expressionsmuster von gG-Zellen beobachten. In den Versuchen mit G-Medium und mit R-Medium wurden nach dieser Zeit jeweils die beständig exprimierten Gene Sox9, Aggrecan und Kollagen I gegenüber der Kontrolle signifikant geringer exprimiert $(\mathrm{p}=<0,05)$. In den 21-tägigen Kulturen mit 
konditionierten Medien wurde in gG-Zellen die mRNA-Expression von Runx2 nachweisbar, jedoch nicht konstant genug für statistisch verwertbare Analysen und valide Aussagen über das Expressionsmuster innerhalb der Versuchsreihe.

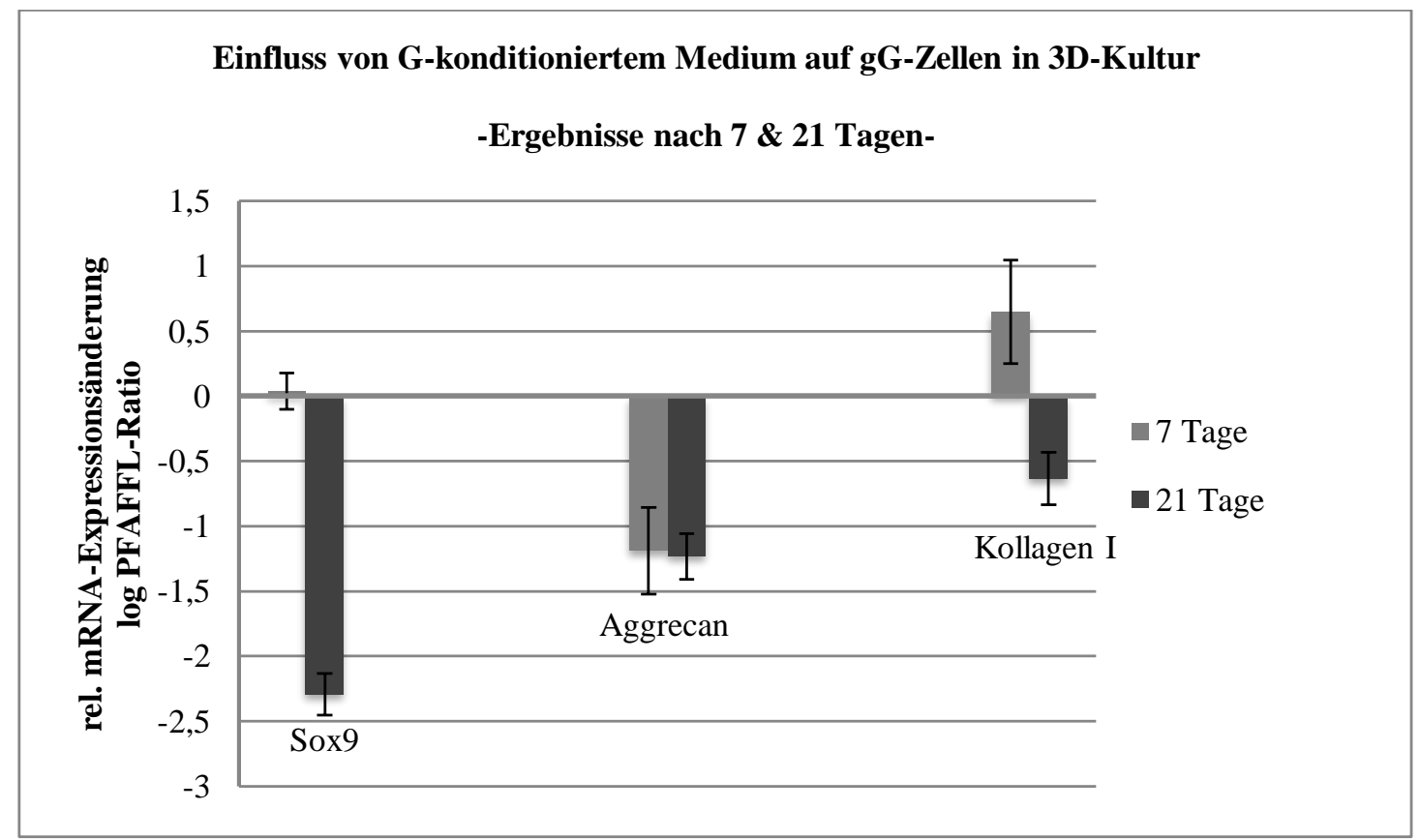

\section{Abbildung 17}

qRT-PCR-Analyse der Veränderungen des Genexpressionsverhaltens von gG-Zellen nach jeweils 7 Tagen (hell) und 21 Tagen (dunkel) in der 3D-Kultur mit G-konditioniertem Medium. Darstellung der relativen mRNA-Expressionsänderung als binärer Logarithmus der PFAFFL-Ratio zur jeweiligen 3D-Kontroll-Kultur. Sox9 (21 Tage), Aggrecan, Kollagen I ( $\mathrm{p}=<0,05)$; Sox9 (7 Tage) $(\mathrm{p}=0,417121)$ 


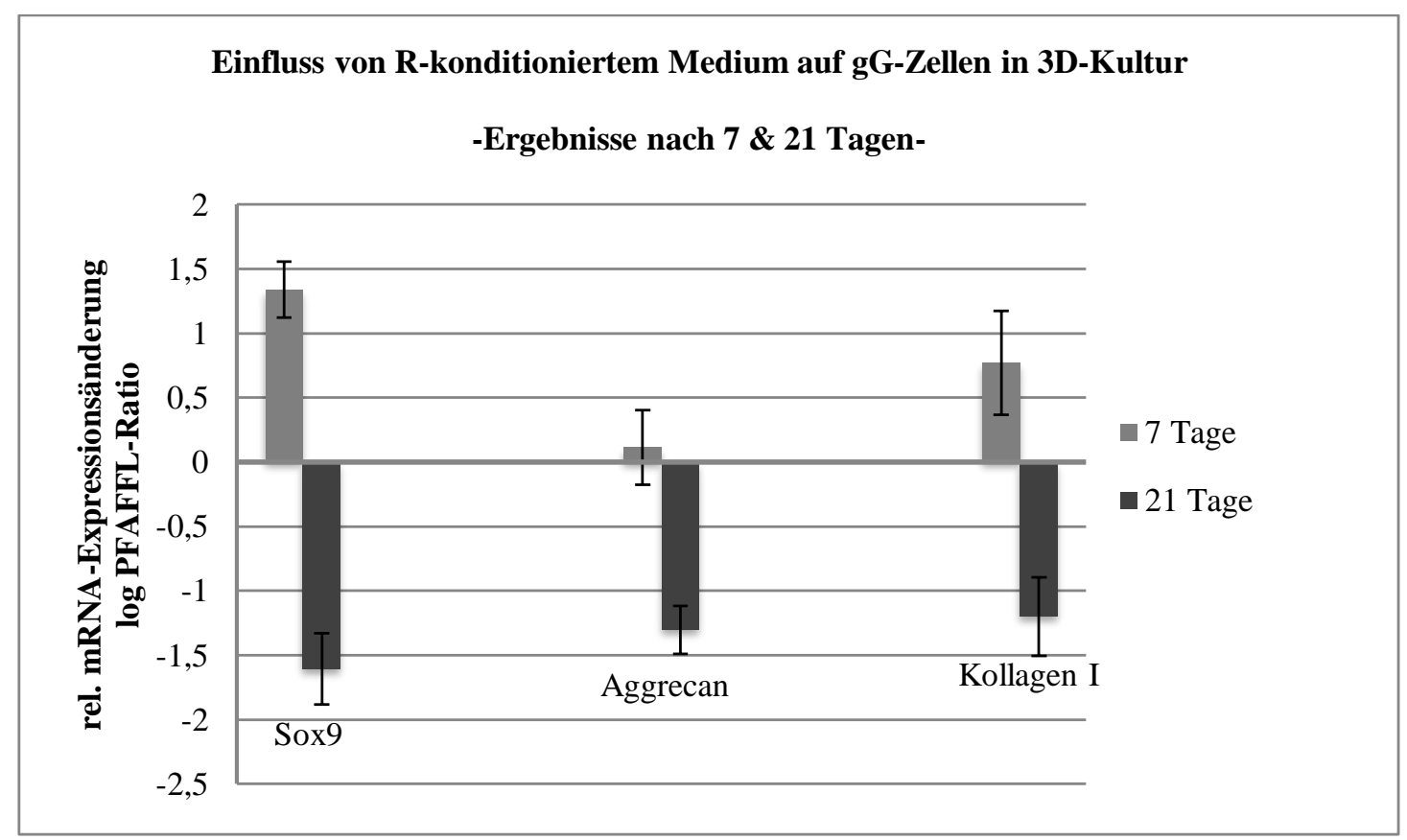

\section{Abbildung 18}

qRT-PCR-Analyse der Veränderungen des Genexpressionsverhaltens von gG-Zellen nach jeweils 7 Tagen (hell) und 21 Tagen (dunkel) in der 3D-Kultur mit R-konditioniertem Medium. Darstellung der relativen mRNA-Expressionsänderung als binärer Logarithmus der PFAFFL-Ratio zur jeweiligen 3D-Kontroll-Kultur. Sox9, Aggrecan (21 Tage), Kollagen I ( $\mathrm{p}=<0,05)$; Aggrecan $(7$ Tage $)(\mathrm{p}=0,269371)$

\subsubsection{Die Wirkung R- und G- konditionierter Medien auf das Expressionsverhalten von CPC}

In den Ergebnissen nach Auswertung der Daten zu den Reaktionen von CPC auf die Kultur in G- und R-Medium nach 7 Tagen sind keine Gegensätze in der Wirkung beider Medien nachzuweisen. Einzig die mRNA-Expression von Sox9 zeigte sich zu diesem Zeitpunkt in Kultur mit R-Medium nur tendenziell erhöht, statistisch zur Kontrollkultur jedoch nicht signifikant verändert ( $\mathrm{p}=0,106077)$. Bei den CPC in der Kultur mit G-Medium war diese Erhöhung hingegen etwas deutlicher ausgeprägt und statistisch signifikant $(p=<0,05)$. Die Expressionswerte von Runx2 und Kollagen I waren nach 7 Tagen im Vergleich zur Kontrolle jeweils signifikant erhöht. Aggrecan wurde von CPC in dieser Versuchsanordnung nach 7 Tagen nicht exprimiert.

Zum Zeitpunkt der 21-tägigen Kultur in konditionierten Medien unterschieden sich die Ergebnisse zwischen G- und R-Mediumkultur in geringem Maße. Allerdings war auch hier keiner der untersuchten mRNA-Werte im Vergleich der Expressionsmuster von G- und RMediumkulturen gegensätzlich verändert. Im Einfluss von G- konditioniertem Medium waren nach 21 Tagen die mRNA-Level aller Gene signifikant reduziert und zeigten sich 
damit weniger stark exprimiert als in der Kontrolle $(\mathrm{p}=<0,05)$. Bei CPC im Einfluss von Rkonditioniertem Medium fand sich ein Expressionsmuster mit weniger herabregulierten Genen. Die RT-PCR wiesen dort für Sox9 eine tendenzielle, aber keine signifikante ( $\mathrm{p}=0,093404$ ), für Runx2 und Kollagen I geringgradig, aber signifikant gesteigerte mRNAWerte gegenüber der Kontrollkultur aus $(\mathrm{p}=<0,05)$. Die Expression von Aggrecan war nach 21 Tagen sowohl in G- als auch in R-Medium verwertbar ausgeprägt und zeigte sich in den CPC jeweils signifikant herunterreguliert.

3.5 Unterschiede und Parallelen in den parakrinen Wirkungen der verschiedenen 3DKo-Kulturen und Alginatkulturen in R- und G-konditionierten Medien

Trennt man die Ergebnisse aller durchgeführten Versuche auf und vergleicht die 3D-KoKulturansätze mit denen der Alginatkultur in konditionierten Medien bezogen auf die Herkunft der Zellen oder des Konditionierungsgewebes in der OA, lassen sich relativ konstante Genregulationen beschreiben.

\subsubsection{Vergleich der Wirkung von Alginatkultur in G-konditioniertem Medium und R-} konditioniertem Medium auf CPC, MSC und gG-Zellen

Im Vergleich der Versuchsergebnisse aus Teil 3.4 wird sehr deutlich, dass die beiden konditionierten Medien aus den unterschiedlichen OA-Bereichen sehr ähnliche Effekte bei allen untersuchten Zellen initiierten. Vor allem MSC und gG-Zellen zeigten langfristig keine Unterschiede in den Expressionsmustern während der Kultur in R-konditioniertem Medium verglichen mit der in G-konditioniertem Medium. Auch die Reaktionen von CPC wiesen in den Versuchen mit den unterschiedlich konditionierten Medien keine gegensätzlichen Entwicklungen auf.

\subsubsection{Die Wirkung von CPC-3D-Ko-Kultur und Alginatkultur in R-konditioniertem} Medium auf MSC und gG-Zellen

Die 3D-Ko-Kultur mit CPC und die Alginatkultur mit R-konditioniertem Medium hatten jeweils nahezu identische Wirkungen auf MSC und gG-Zellen.

In beiden Versuchsanordnungen zeigte sich im Expressionsprofil der gG-Zellen langfristig ein negativer, parakriner Einfluss auf deren Chondrogenität (s. Teil 3.1.1 und 3.1.2).

Auch die Reaktion der MSC in der 3D-Ko-Kultur mit CPC hatte ein exakt gleich gerichtetes Muster wie in der Kultur mit R-konditioniertem Medium. Zu beiden Analysezeitpunkten zeigten sich bei beiden Versuchen geringere Expressionswerte von 
Sox9, Runx2 und Kollagen I verglichen mit der zugehörigen Kontrollkultur. Beide Einflüsse mündeten in einer Verminderung der Expression von allen untersuchten und verwertbar exprimierten Genen in den MSC (s. Teil 3.3.1 und 3.4.1).

\subsubsection{Die unterschiedliche Wirkung von 3D-Ko-Kultur mit CPC und gG-Zellen auf MSC}

CPC, die Progenitorzellen aus dem kranken R-Bereich von OA-Knorpel, stehen bezüglich ihrer Herkunft den gG-Zellen als Repräsentant eines nahezu gesunden Chondrozyten gegenüber. Im Vergleich der Effekte auf das Expressionsmuster während der jeweiligen 3D-Ko-Kultur beider Zellen mit MSC wurde auch ein Gegensatz in ihrer parakrinen Wirkung deutlich. Die 3D-Ko-Kultur mit gG-Zellen führte in den MSC nach 21 Tagen zu einer verstärkten Expression aller untersuchten Gene (s. Teil 2.2.1). In der 3D-Ko-Kultur mit CPC zeigten MSC nach diesem Zeitraum hingegen eine verminderte mRNAExpression aller untersuchten Gene. (s. Teil 3.3.1).

Aggrecan wurde von MSC während der Versuche nicht exprimiert.

\subsubsection{Die Wirkung von Alginatkultur in G-konditioniertem Medium und 3D-Ko-} Kultur mit gG-Zellen auf die Expressionsmuster von MSC und CPC

Anhand der Ergebnisse aus den Versuchen lässt sich auch eine deutliche Abgrenzung der parakrinen Wirkung von G-konditioniertem Medium und der 3D-Ko-Kultur mit gG-Zellen aufzeigen. Es zeigte sich hierbei ein klarer Unterschied zwischen den Reaktionen auf makroskopisch gesunde Bereiche im OA-Knorpel und der Beeinflussung durch nahezu gesunde Knorpelzellen.

CPC exprimierten in der 3D-Ko-Kultur mit gG-Zellen nach 7 Tagen die beiden chondrogenen Marker Sox9 und Aggrecan geringer als in den Kontrollen. Die mRNALevel von Runx2 und Kollagen I, beides Marker chondrozytärer Dedifferenzierung und der Produktion biophysikalisch minderwertiger Knorpelmatrix, zeigten sich erhöht. Nach 21 Tagen blieb die Expression von Sox9 und Aggrecan herunterreguliert. Runx2-mRNA zeigte sich weiter erhöht und Kollagen I kontrollgleiche Werte. In den Versuchen mit GMedium allerdings mündet die langfristige Wirkung in der Herabregulation aller verwertbar exprimierten Gene innerhalb der CPC gegenüber der Kontrolle (s. Teil 3.2.1 und Teil 3.4.3).

Die divergierende Reaktion stellte sich bei den MSC einfacher aber prägnanter dar. Während der 3D-Ko-Kultur mit gG-Zellen zeigte sich eine langfristige Erhöhung der 
Expressionslevel aller untersuchten und exprimierten Gene. Dem steht in den Versuchen mit G-konditioniertem Medium jeweils die langfristige Verminderung dieser mRNAWerte in den MSC entgegen (s. Teil 3.2.2 und Teil 3.4.1). 


\section{Diskussion}

\subsection{Chondrozyten (gG) als parakriner Mediator in 3D-Ko-Kultur mit MSC und CPC}

\subsubsection{Der parakrine Einfluss von Chondrozyten (gG) auf das Genexpressionsmuster von MSC in 3D-Ko-Kultur}

Die Ergebnisse aus den bisherigen Studien konnten CPC, wie beschrieben, als multipotente Progenitorzelle charakterisieren (Koelling et al. 2009; Muhammad et al. 2013). Ihr Differenzierungspotential und ihr CD-Antigenprofil verbindet sie mit den MSC. Für beide Zellreihen ist die Möglichkeit der chondrogenen Differenzierung in vitro beschrieben. Essentielle Grundlage dieser Entwicklung ist eine dreidimensionale Umgebung. Hierin können MSC und CPC zur Ausprägung eines chondrozytären Phänotyps mit entsprechendem Genexpressions- und Proteinbiosynthesemuster angeregt werden (Barry 2003; Koelling et al. 2009). MSC unterliegen in Kulturversuchen zur chondrozytären Differenzierung dem regulatorischen Einfluss trophischer Mediatoren wie TGF- $\beta$, BMP und Wnt, um die aus der Chondrogenese bekannte Entwicklungskaskade zu initiieren und zu durchlaufen (Johnstone et al. 1998; Tuan et al. 2003; Caplan 2007).

Bis dato sind allerdings weder alle parakrinen Mediatoren der Chondrogenese noch deren komplexes zeitliches und konzentrationsabhängiges Zusammenspiel vollständig beschrieben oder reproduziert worden (Aung et al. 2011). Als Quelle eines parakrin mediierten Umfeldes zur chondrozytären Differenzierung ohne den exogenen Zusatz einzelner Wachstumsfaktoren, Cytokine oder Hormone zeigen Ko-Kulturversuche mit differenzierten Chondrozyten vielversprechende Ansätze. In mehreren Studien ist die Induktion einer chondrogenen Differenzierung von Stammzellen über parakrine Zell-ZellInteraktionen mit ausdifferenzierten Chondrozyten beschrieben. Sowohl MSC als auch embryonale Stammzellen (ESC) zeigen in Ko-Kultursystemen mit artikulären Chondrozyten eine signifikante Steigerung der Expression chondrogener Markergene wie Sox9, Aggrecan und Kollagen Typ II (Chen et al. 2009; Varghese et al. 2010; Aung et al. 2011).

In den für die vorliegende Arbeit durchgeführten Untersuchungen findet sich ein differenziertes Bild der zellulären Entwicklung innerhalb der parakrinen Interaktion von MSC mit Chondrozyten. Die MSC zeigten ein signifikant verändertes Muster ihrer mRNA-Expressionslevel von Sox9, Runx2 und Kollagen Typ I gegenüber der zeitgleichen 
Alginatmonokultur. Nach 7 Tagen ließ sich noch für jedes dieser Gene ein vermindertes Expressionsniveau finden. Mit längerer Versuchsdauer wird in Analysen des Genexpressionsmusters von MSC in der 3D-Alginat-Ko-Kultur mit gG nach 21 Tagen der wichtigste chondrozytäre Transkriptionsfaktor Sox9 signifikant verstärkt exprimiert. Über diesen Zeitraum war gleichzeitig auch die mRNA-Expression von Runx2 und Kollagen Typ I gegenüber der Kontrolle signifikant gesteigert. Es zeigte sich eine parakrin vermittelte Veränderung des Genexpressionsmusters der MSC, die sich keiner eindeutigen Differenzierungsrichtung zuordnen lässt. In Anbetracht der Intention dieser Interaktion weisen die Ergebnisse nur partielle Charakteristika einer chondrogenen Differenzierung nach. Diese Ergebnisse zeigen sich konkordant mit den Ergebnissen anderer Forschungsgruppen zu chondrogenen Differenzierungsprozessen von Stammzellen. Rothenberg et al. (2011) zeigten in Ko-Kulturversuchen von MSC mit Chondrozyten ebenfalls, dass sich keine eindeutig chondrogene Differenzierung der MSC nachweisen lässt und diese zeitgleich eine Expression osteogener Marker aufweisen. Auch Mo et al. (2009) wiesen innerhalb einer solchen Ko-Kulturuntersuchung Charakteristika sowohl chondrogener als auch osteogener, fibroblastenartiger Differenzierungstendenzen in den MSC nach. Die Ausprägung der einzelnen Differenzierungsrichtung in den Stammzellen konnte hierbei in Zusammenhang mit dem Verhältnis der MSC zu Chondrozyten gebracht werden (Mo et al. 2009). MSC zeigten, gemessen an der Expression von Runx2 und Osteocalcin in parakriner Mediation über eine Ko-Kultur mit Chondrozyten in einer Untersuchung von Gerstenfeld et al. (2002) sogar eine stärkere osteogene Differenzierungstendenz auf, als in Ko-Kultur mit Osteoblasten oder Fibroblasten. Des Weiteren beschreiben auch Varghese et al. (2010) in ihren Untersuchungen zur Chondrozyten-Ko-Kultur basierten Differenzierung von ESC, dass nicht alle Zellen chondrogen differenziert werden können, sondern einige Zellen einen fibroblastenartigen Phänotyp entwickeln.

Bekanntermaßen ist die Chondrogenese ein komplexer, zeitlich und konzentrationsabhängig dirigierter Prozess. Im Rahmen skelettogenetischer Entwicklungsschritte an der Wachstumsplatte entwickeln sich nur wenige Zellen aus der gemeinsamen Anlage von Knochen und Knorpel zu ausdifferenzierten Chondrozyten und produzieren die einzigartige EZM des hyalinen Gelenkknorpels (Muir 1995, Archer und Francis-West 2003). Eine Mehrheit dieser Zellen durchläuft die hypertrophe Entwicklung zur terminalen 
Differenzierung und vollzieht damit die enchondrale Ossifikation für das knöcherne Längswachstum (Lefebvre und Smits 2005; Aigner und Gerwin 2007).

MSC wird eine multipotente Differenzierungsfähigkeit zugesprochen, so dass die mRNAExpressionsveränderungen in den hier durchgeführten Untersuchungen im Kontext der Chondrogenese betrachtet werden. Aus diesem Blickwinkel kann kein endgültiger Rückschluss auf die eingeschlagene Differenzierungsrichtung gezogen werden. Eine zeitgleiche Steigerung der Expression von jeweils einem der wichtigsten chondrogenen und osteogenen Transkriptionsfaktoren, Sox9 und Runx2, findet sich in der humanen Knorpelentwicklung, vor allem zu Beginn, nicht (Lefebvre und Smits 2005; Goldring et al. 2006). Im Ablauf der Chondrogenese verläuft die Expression dieser Regulatoren gegensätzlich (Lefebvre und Smits 2005; Bobick et al. 2009). Einzig für vorherig chondrozytär ausdifferenzierte Zellen könnte das abgebildete Expressionsmuster mit einer gesteigerten Genexpression aller drei Gene gegenüber der Monokultur auch einen Übergang in die prähypertrophe Entwicklung charakterisieren. In diesem sind Sox9 und Runx2 parallel exprimiert und die Synthese von Kollagen Typ I steigt (Lefebvre und Smits 2005; Goldring et al. 2006).

Die signifikante Steigerung der Genexpressionsniveaus von Sox9, Runx2 und Kollagen Typ I gegenüber der Alginat-Monokultur charakterisiert eine anabole Differenzierungsreaktion mit der Ausprägung einer gemischt chondrogenen und osteogenfibroblastenartigen Zellentwicklung. Das Muster der Genexpression zeigt interessanterweise große Parallelen zu dem originären Phänotyp der CPC. Im Rahmen der Erstbeschreibung der CPC durch Koelling et al. (2009) wurde mittels rt-PCRUntersuchungen und immunhistochemischen Analysen der nativen Zellen ein charakterisierendes, bis dato nicht vergleichbares Expressions- und Proteinbiosynthesemuster beschrieben. CPC zeigen ein intermediäres Level der relativen Expression von Sox9 und Runx2 sowie ein hohes Level der Kollagen Typ I Expression (Koelling et al. 2009). In einem Vergleich mit Chondrozyten und osteoblastären Zellen ließen sich die CPC keiner der beiden ausdifferenzierten Zellreihen zuordnen. Chondrozyten zeigen eine erwartungsgemäß hohe Expression von Kollagen Typ II, Sox9 wird auf intermediärem Niveau exprimiert und Runx2 sowie Kollagen Typ I sind nur sehr gering nachweisbar. Osteoblastäre Zellen sind charakterisiert durch hohe Expressionslevel von Runx2 und Kollagen Typ I. CPC weisen in diesem Vergleich somit ein 
Expressionsmuster auf, dem sowohl charakteristische chondrogene als auch osteogene Marker zugeordnet werden können (Koelling et al. 2009; Gerter et al. 2012).

In Zusammenschau bieten die Ergebnisse Anlass zu der Annahme, dass MSC unter dem Einfluss der beschriebenen Zellen und Gewebe zur chondrogenetischen Differenzierung in vitro eine Entwicklung unterlaufen, die die vermutete Entwicklung im Entstehungsprozess der CPC reproduziert. In der Folge sollte für therapeutische Ansätze zur zellbasierten Therapie mit MSC auch die Betrachtung aller Einflüsse im erkrankten Gewebe auf die Entwicklung der MSC berücksichtigt werden. Im Umkehrschluss kann den CPC unterstellt werden, dass diese in der OA schon einer Entwicklung unterlaufen sind, die den MSC nach therapeutischer Transplantation noch bevorstünde.

\subsubsection{Der parakrine Einfluss von Chondrozyten (gG) auf das Genexpressionsmuster von CPC in 3D-Ko-Kultur}

In Versuchen zur chondrogenen Differenzierung isolierter CPC zeigten diese, anders als native MSC, ein auffallend hohes intrinsisches chondrogenes Potential (Koelling et al. 2009; Koelling und Miosge 2009; Gerter et al. 2012). Allein durch Kultivierung im dreidimensionalen Umfeld einer Alginatkultur ließ sich auch ohne Zugabe exogener Faktoren eine deutliche, chondrogene Entwicklung der CPC anregen (Koelling et al. 2009). Die CPC zeigten dabei neben einem runden, chondrozytärem Phänotyp eine nachweisbare Synthese von Kollagen Typ II, hohe mRNA-Level von Sox9 und Kollagen Typ II bei gleichzeitig niedrigen Expressionsniveaus von Runx2- und Kollagen Typ ImRNA (Koelling et al. 2009). Dazu passend findet sich in den hier durchgeführten Versuchen im Gegensatz zu den MSC eine persistente Genexpression des Proteoglykans Aggrecan. Eine Zunahme der Kollagen Typ II-Expression und eine Suppression derer von Runx2, Kollagen Typ I sowie des knorpeldegradierenden Enzyms MMP-13 durch Supplementierung von TGF- $\beta 3$ und BMP-6 in den Untersuchungen von Koelling et al. (2009) belegen die Möglichkeit einer parakrinen Modulation der Differenzierung von CPC.

Die Kenntnisse über die intrinsische Aktivierung und dem Potential chondrogener Entwicklung der CPC in 3D-Kultur dienen als wichtige Basis zur Interpretation der folgenden Untersuchungsergebnisse.

In parakriner Interaktion mit gG zeigen die CPC gegenüber ihrer Alginat-Monokultur über den gesamten Untersuchungszeitraum eine signifikant verminderte chondrogene 
Entwicklung. Die mRNA-Expression des wichtigsten chondrogenen Transkriptionsfaktors Sox9 ist im Sinne der reduzierten chondrogenen Differenzierung im Verlauf signifikant unterdrückt. Das charakteristische Proteoglykan Aggrecan zeigt sich in dieser Versuchsanordnung weiter nachweisbar, in seiner Höhe und Konstanz jedoch nicht mehr statistisch auswertbar. Die Markergene einer osteogen-fibroblastenähnlichen Entwicklung, Runx2 und Kollagen Typ I, hingegen sind in der Analyse während des gesamten Untersuchungszeitraumes gegenüber der Kontrolle signifikant verstärkt (Runx2) und wenigstens, wenn auch nicht signifikant, konstant (Kollagen Typ I) exprimiert.

Die CPC prägen in diesem parakrinen Einfluss ein unerwartet deutlich verstärkt osteogenfibroblastenartiges und vermindert chondrogenes Expressionsmuster aus.

Diese Entwicklung und die Stabilität des Genexpressionmusters in der Interaktion mit gGZellen markieren eine Differenz von CPC und MSC in vitro. Zu berücksichtigen ist dabei, dass die MSC kein mit den CPC vergleichbares intrinsisches chondrogenes Potential in 3D-Umgebung haben. Wie erwähnt ist für ihre chondrogene Differenzierung die exogene Supplementierung von Wachstumsfaktoren, Cytokinen und Hormonen obligat (Muhammad et al. 2013). Damit ist nur ein quantitativer Vergleich ihrer Entwicklungen, jeweils bezogen auf die eigene Kontrollkultur möglich.

CPC konnten aufgrund ihrer migratorischen Aktivität aus destruierten Arealen des osteoarthrotischen Knorpels, beziehungsweise dem Reparaturgewebe isoliert werden. Diese Herkunft bedingt eine längerfristige Präsenz von parakrinen Einflüssen der OA. Osteoarthrotisch veränderte Chondrozyten, Synovia und subchondraler Knochen produzieren Faktoren, wie inflammatorische Cytokine, die einen erheblichen Einfluss auf den in vivo Reparaturprozess und damit auch auf residente Progenitorzellen haben (Koelling und Miosge 2009; Mabvuure et al. 2012). Dieses parakrine Milieu vermittelt eine Prädifferenzierung der CPC mit Ausprägung ihres gemischt osteogenfibroblastenartigen und chondrogenen Phänotyps. Zeitgleich kennzeichnet die CPC hierunter ihr multipotentes Differenzierungspotential mit einem ausgeprägten chondrogenen Entwicklungsvermögen. Die CPC befinden sich damit als Progenitorzelle allerdings nicht mehr am naiven Beginn ihrer Differenzierbarkeit.

Die 3D-Ko-Kultur von CPC und gG zeigt trotz der Möglichkeiten einer parakrinen Steigerung der Chondrogenität keine chondrogene Entwicklung der CPC. Dies wirft die Frage auf, ob CPC in vivo einem radikal anderen chondrozytärem Einfluss unterliegen. In vitro-Versuche widerlegen diese Vermutung. Auch für OA-Chondrozyten ist beschrieben, 
über parakrine Interaktionen eine chondrogene Differenzierung mesenchymaler Stammzellen zu induzieren. Ohne Zugabe exogener chondrogen stimulierender Faktoren zeigten native MSC in Ko-Kultur-Versuchen mit osteoarthrotischen Chondrozyten eine Zunahme der Expression chondrogener Markergene (Aung et al. 2011; Diao et al. 2013). In Zusammenschau der Ergebnisse lässt sich diesbezüglich vermuten, dass die parakrin vermittelten chondrozytären Einflüsse auf differenzierungsfähige Zellen innerhalb des erkrankten Gelenkes sich nicht radikal von denen gesunder Knorpelzellen unterscheiden. Die stabile Reaktion der CPC in 3D-Ko-Kultur mit gG, beruhend auf der Prädifferenzierung im OA-Gelenk, könnte damit eine Fortsetzung der eingespielten Interaktion zwischen CPC und OA-Chondrozyten im osteoarthrotischen Gelenkknorpel widerspiegeln. Die pathologisch veränderten Chondrozyten hätten, in Anbetracht des Resultates der gemeinsamen 3D-Ko-Kultur, somit einen maßgeblichen Anteil an dem osteogen-fibroblastenartigen Charakter des originären Phänotyps der multipotenten CPC.

Allerdings ist die Gesamtheit des parakrinen osteoarthrotischen Milieus und deren Einfluss auf beteiligte Zellen bis dato nicht vollständig beschrieben.

Die Unfähigkeit, unter den Bedingungen der Osteoarthrose eine suffiziente Chondrogenese und einen vollständigen Reparaturprozess zu vollziehen, zeigt sich in vivo auch durch die Progredienz der Erkrankung trotz des Nachweises einer Progenitorzellreihe mit hohem chondrogenen Entwicklungspotential wie der CPC. Aufgrund der Parallelen zu MSC in in vitro-Versuchen und der vermuteten mesenchymalen Herkunft von CPC kann resümiert werden, dass im osteoarthrotischen Umfeld für zellbasierte Therapieansätze mit multipotenten Stamm- oder Progenitorzellen eine dauerhafte chondrozytäre Entwicklung unwahrscheinlich ist. Auch Heldens et al. (2012) geben diesbezüglich zu bedenken, dass alle therapeutischen Konstrukte, die in das erkrankte Gelenk und den Knorpel eingebracht werden dem parakrinen OA-Umfeld ausgesetzt sind. Aufgrund ihres Ursprunges aus dem osteoarthrotischen Gewebe und der stabilen Expression ihres Phänotypes mit multipotentem Differenzierungspotential sind die CPC von besonderem Interesse für die regenerative Medizin (Koelling und Miosge 2009; Khan et al. 2009; Gerter et al. 2012). 


\subsection{Parakrine Einflüsse von MSC und CPC auf das Genexpressionsmuster von}

\section{Chondrozyten}

\subsubsection{CPC als parakriner Mediator - Einfluss auf die Expression von osteogenen und chondrozytären Markergenen von gG-Zellen in 3D-Ko-Kultur}

CPC vereinen, bezogen auf die OA, zwei wichtige Eigenschaften. Zum einen werden ihnen als multipotente Progenitorzellen mit hohem chondrogenen Potential therapeutische Möglichkeiten zugeschrieben (Koelling et al. 2009; Gerter et al. 2012). Auf der anderen Seite sind sie die bisher einzige Zelle dieser Art mit Herkunft aus makroskopisch deutlich degradiertem Knorpelgewebe im OA Gelenk und damit bezüglich ihrer Herkunft, Funktion und Eigenschaften von pathogenetischem Interesse (Khan et al. 2009; Gerter et al. 2012). In diesen Versuchen wird erstmals evaluiert welchen Einfluss die CPC, isoliert aus dem OA-Umfeld, über eine parakrine Interaktion mit anderen Zellen ausüben. Dabei stehen die Reaktionen in Interaktion mit gesunden Chondrozyten im Mittelpunkt.

Die CPC induzieren in dieser 3D-Ko-Kultur mit $\mathrm{gG}$ initial ein signifikant verstärkt chondrogenes Expressionsmuster. In den qRT-PCR-Analysen lässt sich nach einer Versuchsdauer von 7 Tagen eine signifikante mRNA-Expressionssteigerung der spezifischen chondrogenen Markergene Sox9 und Aggrecan in den gG nachweisen. Parallel zeigt sich eine signifikante Suppression der mRNA-Level von Kollagen Typ I in den gG. Die verringerte Expression von Kollagen Typ I, als Marker eines chondrozytären Dedifferenzierungsprozesses hin zu einem fibroblastenartigen/hypertrophen Phänotyp (Miosge et al. 2004), unterstreicht die chondrogene Entwicklungsrichtung. Runx2 wird, als Zeichen eines konstanten chondrogenen Phänotypes der gG, erwartungsgemäß in keinem Versuchsansatz exprimiert. Nach 21 Tagen erschöpft sich diese Reaktion, es zeigen sich dann im Vergleich zur Alginat-Monokultur der gG verminderte Expressionsraten aller untersuchten Gene.

Auch nach Passagierung zur Zellzahlvermehrung und damit einhergehender Dedifferenzierungsprozesse in vitro bleibt Knorpelzellen ihr chondrogenes Potential erhalten und sie durchlaufen in einer 3D-Matrix einen intrinsischen Redifferenzierungsprozess (Schnabel et al. 2002; Tallheden et al. 2004). Ohne Zugabe von exogenen Wachstumsfaktoren erlangen diese ihren charakteristischen chondrozytären Phänotyp mit entsprechender Genexpression und Matrixsynthese zurück (Huch et al. 2002; Schulze-Tanzil et al. 2002; Tallheden et al. 2004). Daher sind die chondrozytären 
Entwicklungen innerhalb der Versuche in dieser Arbeit das Resultat aus den parakrinen Interaktionen und basieren vermutlich nicht auf einem Dedifferenzierungsprozess. Die Interaktion der CPC mit gG steigert deren chondrogenes Expressionsmuster auch gegenüber der Entwicklung zum originären chondrozytären Phänotyp in der Alginatkultur. Jedoch zeigt sich auch im Rahmen der chondrozytären Entwicklung in frühen Stadien der OA eine Steigerung der Expression und Synthese von Markern einer fibroblastenartigen Dedifferenzierung wie Runx2, Kollagen Typ I und Kollagen Typ X (Von der Mark und Glückert 1990; Miosge et al. 2004; Horton et al. 2006). Für diese Induktion der fibroblastenartigen und hypertrophen Dedifferenzierung der Knorpelzellen sind ebenfalls mehrere parakrine Mediatoren verantwortlich (Sandell und Aigner 2001; Goldring und Goldring 2007; Umlauf et al. 2010).

Zur Charakterisierung der chondrozytären Reaktion in parakriner Interaktion mit CPC fand sich in dieser Arbeit ein weiterer wichtiger Unterschied $\mathrm{zu}$ dem Einfluss eines pathologischen Mediums auf gG-Zellen. Auch die 3D-Alginatkulturversuche mit von Rosteoarthrotischem Knorpel konditioniertem Medium bewirken eine initiale anabole Reaktion in den untersuchten Chondrozyten. Dieses Medium repräsentiert die Gesamtheit parakriner Mediatoren, synthetisiert von pathologischem OA-Knorpel aus makroskopisch stark degradierten Arealen. Nach 7 Tagen findet sich in dieser Versuchsanordnung eine Genexpressionssteigerung von Sox9 und in der Tendenz, jedoch ohne statistische Signifikanz auch von Aggrecan in den gG-Zellen. Allerdings zeigt sich, gegenüber der Kontrolle, zeitgleich auch die mRNA-Expression von Kollagen Typ I signifikant erhöht. Diese Erhöhung betrifft damit einen der wichtigsten Marker der pathologischen hypertrophen, fibrokartilaginären Entwicklung und Dedifferenzierung ausdifferenzierter Chondrozyten im Gelenknorpel und in vitro: Kollagen Typ I (Von der Mark und Glückert 1990; Tesche und Miosge 2005; Aigner et al. 2007).

Eine vergleichbare, undifferenzierte Entwicklung der Chondrozyten und Ausprägung eines dedifferenzierten Phänotyps demonstrieren auch andere Untersuchungen zur Interaktion von Chondrozyten mit Geweben und Zellen deren Einflüssen sie im originären Gelenk nicht ausgesetzt sind. Auf Basis des Umfeldes von Knorpeltransplantaten bei autologer Knorpeltransplantation untersuchten Grässel et al. (2010) die parakrine Interaktion von artikulären Chondrozyten und Periostexplantaten. Auch diese Interaktion findet in physiologischen Gelenken nicht statt, tidemark-Brüche und damit die Aufhebung der Knorpel-Knochen-Grenze werden erst im Rahmen der OA sichtbar (Walsh et al. 2007; 
Koelling et al. 2009). In den untersuchten Chondrozyten fand sich ein anaboler Effekt, einhergehend mit einer gesteigerten Synthese von Kollagen Typ I, und damit ebenfalls ohne Nachweis einer differenzierten chondrogenen Entwicklung (Grässel et al. 2010). Sanchez et al. (2005) beschreiben eine, durch Ko-Kulturen mit subchondralen Osteoblasten induzierte, hypertrophe Entwicklung im Expressionsmuster von OAChondrozyten. Die Knochenzellen aus dem erkrankten subchondralen Gewebe reduzieren die mRNA-Expression von Sox9, Aggrecan und Kollagen Typ II damit die Chondrogenität der Zellen im Vergleich mit einer Alginat-Monokultur des originären chondrozytären Phänotyps (Sanchez et al. 2005).

Die Ergebnisse der hier vorliegenden Arbeit charakterisieren erstmals die Eigenschaften der CPC als trophischer Mediator. Vor allem die Möglichkeit einer differenzierten Steigerung des chondrogenen Profils im Expressions- und Synthesemuster der Chondrozyten zeigt eine weitere Eigenschaft der CPC auf, deren Bedeutung für mögliche Therapieansätze zu evaluieren sein wird.

Die parakrine Mediation stellt eine weitere Verbindung zwischen CPC und mesenchymalen Stammzellen dar. In zahlreichen Untersuchungen $\mathrm{zu}$ potentiell therapeutisch nutzbaren Eigenschaften der MSC ist die trophische Mediation als bedeutsame Fähigkeit in den Fokus gerückt (Caplan und Dennis 2006; Arthur et al. 2009; Barry und Murphy 2013).

\subsubsection{MSC als parakriner Mediator - Modulation des Genexpressionsmusters von gG- Zellen in 3D-Ko-Kultur}

Durch Sekretion parakriner Faktoren und immunomodulatorischer Fähigkeiten können mesenchymale Stammzellen bedeutsame Einflüsse auf residente Zellen und Gewebe ausüben (Caplan 2009; Arthur et al. 2009). Die therapeutischen Einsatzmöglichkeiten der MSC umfassen somit zwei zentrale Ansätze. Sie können als Zellquelle für die Gewebeneubildung dienen, aber auch als Ressource von zahlreichen parakrinen Faktoren modifizierend und restrukturierend auf die ansässigen Zellen wirken (Kassem und Abdallah 2008; Arthur et al. 2009; Barry und Murphy 2013).

Ein solcher positiver Effekt auf Differenzierungsverhalten ist in Regenerationsexperimenten von Gewebe des Herzmuskels, der Menisci und des Gehirns beschrieben. Mittlerweile konnte auch schon eine klinische Relevanz dieser Fähigkeiten unter anderem in der Forschung zu M. Crohn, Graft-versus-Host Diseases und Diabetes mellitus Typ I 
nachgewiesen werden (Caplan und Dennis 2006; Kaplan et al. 2011). Caplan (2009) spricht in Zusammenhang mit der Nutzung parakriner Eigenschaften der MSC von einer neuen Ära zellbasierter orthopädischer Therapiemöglichkeiten. Besondere Bedeutung für die OA-Forschung haben dabei die Hemmung von Fibrosierungsprozessen, die Immunmodulation durch bioaktive Faktoren von MSC und die Einflussnahme auf die Differenzierung von gewebeeigenen Zellen (Caplan und Dennis 2006; Kaplan et al. 2011). Mit Untersuchungen einzelner parakriner Interaktionen könnte ein wichtiger Effekt für Geweberegenerationsforschung des Bewegungsapparates evaluiert werden (Caplan 2009; Rothenberg et al. 2011).

In dieser Arbeit zeigt die Analyse der Expressionsreaktionen von gG-Zellen in der 3D-KoKultur mit MSC die einzige Konstellation, in der ihr chondrogenes Expressionsmuster stabil und langfristig verstärkt wird. Diese Untersuchungen belegen die positiven parakrinen Eigenschaften der MSC auf ausdifferenzierte Zellen. Der chondrogene Transkriptionsfaktor Sox9 wird auf der analysierten mRNA-Ebene initial verstärkt und im Verlauf stabil, Aggrecan sogar konstant stärker exprimiert als in Alginat-Monokultur. Parallel dazu lässt sich die chondrogene Entwicklung mit einer persistenten Verminderung der Kollagen-Typ I Expression untermauern.

Analog zu den Ergebnissen dieser Arbeit zeigten andere Arbeitsgruppen in Ko-Kulturen ebenfalls erhöhte Genexpressionen für Aggrecan, Sox9 und auch Kollagen Typ II in Chondrozyten im Einfluss mesenchymaler Stammzellen (Meretoja et al. 2012; Wu et al. 2012). Bei Versuchen einer gemeinsamen 3D-Ko-Kultur von Chondrozyten und MSC wiesen Zuo et al. (2013) eine deutlich gesteigerte chondrogene Matrixproduktion in den Zellpellets nach. Die weitere Untersuchung zeigte, dass dafür vor allem die gesteigerte chondrogene Aktivität der Chondrozyten in Interaktion mit den MSC verantwortlich war, als eine chondrogene Differenzierung der MSC (Zuo et al. 2013). Wichtig ist, dass diese Effekte nur, wie hier, in 3D-Ko-Kulturen ersichtlich waren. In 2D-Untersuchungen dedifferenzieren Chondrozyten und zeigen auch unter Einfluss von MSC eine osteogene Entwicklung (Rothenberg et al. 2011).

Diao et al. (2013) wiesen in Ko-Kulturversuchen von osteoarthrotischen Chondrozyten mit mesenchymalen Stammzellen eine parakrin mediierte Inhibition terminaler Differenzierungsvorgänge in den erkrankten Knorpelzellen nach. Die stärkste Suppression von pathologischen Proliferationsvorgängen und der MMP-13 Synthese in Ko-Kulturen ging von MSC mit chondrogener Prädifferenzierung aus (Diao et al. 2013). Bezogen auf 
die In-Vivo-Verhältnisse in der OA ist die Prädifferenzierung der CPC vermutlich ein wichtiger Parameter ihrer dortigen Wirkung. So ändert sich im Rahmen einer osteogenen Differenzierung auch das Profil der Sekretion bioaktiver Faktoren in mesenchymalen Stammzellen und damit einhergehend auch deren therapeutische Modalitäten (Rothenberg et al. 2011). Rothenberg et al. (2011) untersuchten den Einfluss mesenchymaler Stammzellen in verschiedenen Stadien einer osteogenen Differenzierung in Ko-Kultur mit Chondrozyten. Abhängig von der Dauer einer Prädifferenzierung der Stammzellen in osteogenem Medium zeigten sich unterschiedliche Effekte auf die Chondrogenität der kokultivierten Chondrozyten. Mit einer längeren Prädifferenzierung zeigte sich ein stetig abnehmender Einfluss auf die chondrogene Entwicklung der Knorpelzellen (Rothenberg et al. 2011). Aufgrund der vermuteten längerfristigen Verweildauer von CPC im osteoarthrotischen Kniegelenk kann die Prädifferenzierung ein wichtiger Faktor sein, der dazu führt, dass CPC keinen dauerhaften Effekt auf die chondrogene Entwicklung osteoarthrotischer Chondrozyten in vivo vermitteln. Die Evaluation des Einflusses von siRNA-knockdown-Versuchen, wie beispielsweise für Runx2 erfolgreich beschrieben (Koelling et al. 2009), auf die von den CPC ausgehenden parakrinen Effekte auf ansässige Zellen in der OA wären für weitere Studien von großem Interesse. Bezüglich der Entwicklung einer potentiellen Nutzung der CPC als parakrinen Mediator in vivo charakterisiert die Fähigkeit zur Migration in den Gelenkknorpel ein wichtiges Merkmal.

\subsection{Konditioniertes Medium aus OA-Gelenkknorpel - parakriner Einfluss auf Zellen in 3D-Kultur und vergleichende Analyse der Relevanz makroskopischer Unterschiede des Defektareals im OA-Gelenkknorpel}

Die initialen Reaktionen der gG-Zellen auf die Alginatkultur in Medien, konditioniert mit Knorpelfragmenten verschiedener OA-Areale ( $R$ und $G$ ), zeigen das Muster einer zellulären Aktivierung. Dieses folgt, mit längerer Versuchsdauer, eine alle exprimierten Gene betreffende mRNA-Expressionsverminderung. R- und G-klassifizierte Knorpelareale entsprechen makroskopisch unterschiedlich degradierten Anteilen des osteoarthrotischen Gewebes in vivo. Trotz der deutlich erscheinenden Unterschiede zwischen einzelnen Gelenkbereichen, lässt sich schon in biochemischen, molekulargenetischen und histologischen Untersuchungen zeigen, dass die OA eine das gesamte Gelenk betreffende Erkrankung darstellt (Goldring 2012). Ihre Pathogenese ist geprägt von im gesamten Gelenkknorpel auffindbaren, unterschiedlich veränderten Chondrozyten und charakterisiert 
somit keine lokal abgrenzbare Destruktion (Horton et al. 2006; Aigner et al. 2007). Sato et al. (2006) untersuchten in einer PCR-und Microarray-Analyse die Expressionsunterschiede zahlreicher Gene zwischen makroskopisch unterschiedlich arrodierten Knorpelzonen osteoarthrotischer Gelenke von insgesamt 15 Patienten. Als Ausdruck der matrixsynthetischen Aktivitätssteigerung zeigte sich ein, nicht zonendifferentes, hohes Expressionsniveau der wichtigen knorpelspezifischen Matrixkomponenten Aggrecan und Kollagen Typ II. Die Sox9-Expression wies Unterschiede zwischen den Zelltypen auf, jedoch fanden sich kaum Expressionsunterschiede zwischen Knorpelarealen verschiedener Destruktionsgrade. Kollagen I ist hingegen, als Zeichen fortschreitender Dedifferenzierung und Entwicklung eines hypertrophen Phänotyps, in destruierten Bereichen stärker exprimiert als von Chondrozyten in makroskopisch intaktem Gewebe (Sato et al. 2006).

In der vorliegenden Arbeit kann gezeigt werden, dass auch parakrine Mediatoren, ausgehend von den unterschiedlich destruierten Arealen des OA-Gelenkknorpels, nahezu identische Effekte auf gG-Zellen vermittelt. Resultierend in einer, gegenüber der Kontrolle, signifikanten Reduktion der Chondrogenität im Genexpressionsmuster von chondrozytären Zellen. R-konditioniertes Medium induzierte eine signifikant gesteigerte mRNA-Expression von Sox9 und Kollagen Typ I nach 7-tägiger Versuchsdauer sowie in der Tendenz (ohne statistische Signifikanz) von Aggrecan. Auch in Kultur mit Gkonditionierten Medien zeigen sich gesteigerte Expressionsniveaus von Sox9 und Kollagen Typ I. Aggrecan zeigt sich hier jedoch schon nach 7 Tagen geringer exprimiert. Als Kontrolle diente eine zeitgleiche Alginatkultur der $\mathrm{gG}-$ Zellen in unkonditioniertem Medium, das mit der beschriebenen Persistenz und Entwicklung ihres ausdifferenzierten chondrozytären Phänotyps einhergeht. Langfristig führen beide konditionierte Medien zu einem Genexpressionsmuster, das partiell einer induzierten Dedifferenzierung mit einem fibroblastenähnlichen Expressionsmuster zuzuordnen ist.

$\mathrm{Zu}$ berücksichtigen ist für die beschriebenen Versuche in konditionierten Medien, dass keine direkten zellulären Interaktionen bestehen. So sind im Vergleich direkter KoKulturen, unter Gewährung direkter zellulärer Interaktionen, mit Versuchen unter Nutzung konditionierter Medien der gleichen Zellen und Gewebe zum Teil differente Effekte beschrieben (Jikko et al. 1999; Fischer et al. 2010).

Unabhängig von der Makroskopie des osteoarthrotischen Knorpelareals vermitteln die OAKnorpel-konditionierten Medien in den durchgeführten Versuchen einen nahezu 
identischen parakrinen Effekt auf die Entwicklung der gG-Zellen. Wie beschrieben mit dem Resultat einer signifikanten Verminderung ihrer Chondrogenität.

Auch in Anbetracht der Analysen von MSC in den OA-Knorpel konditionierten Medien lässt sich zeigen, dass der parakrine Einfluss beider Areale sich vor allem langfristig kaum unterscheidet. Pathologischer Gelenkknorpel bewirkt als Ausgangsquelle für konditioniertes Medium im Vergleich $\mathrm{zu}$ unkonditionierten Kulturmedien in 3DAlginatkulturen zu keinem Versuchszeitpunkt eine Genexpressionssteigerung in MSC.

Dass sich über konditionierte Medien Differenzierungen in MSC induzieren lassen, zeigten Hwang et al. (2007). In den hier durchgeführten Analysen wird keines der untersuchten Markergene weder einer chondrogenen noch einer osteogen-fibroblastenartigen Entwicklung durch den azellulären Einfluss der konditionierten Medien über das Niveau einer Alginatmonokultur hochreguliert.

Auch wenn sich das konditionierte Medium, wie erwähnt, nicht vollends mit den in vivo vorkommenden Verhältnissen vergleichen lässt, so scheinen auch die makroskopisch vitalen Knorpelareale in der OA keine differenzierenden, sondern vornehmlich pathologische Veränderungen zu generieren. Noch konnte nicht differenziert aufgezeigt werden, woran langfristige Erfolge von In-Vivo-Modellen zellbasierter, regenerativer Therapien scheitern. Die Herausforderung für alle tissue-engineering- und zellbasierten Therapieansätze wird es sein, auch die parakrinen Einflüsse und zellulären Interaktionen in der OA zu isolieren, zu bedenken und nach Möglichkeit zu modulieren. 


\section{Zusammenfassung}

Die Osteoarthrose beschreibt eine Erkrankung mit multifaktoriell bedingter Knorpeldegeneration. Innerhalb des betroffenen Gelenkes stehen mehrere Gewebe und Zellen in unterschiedlichen Differenzierungsstadien in Wechselwirkung. Große Bedeutung für den avaskulären Knorpel haben parakrine Einflüsse und Interaktionen.

Ihnen wird eine hohe Relevanz sowohl im pathogenetischen Prozess der Osteoarthrose als auch für mögliche zellbasierte Therapien zugeschrieben. Vor diesem Hintergrund war es das Ziel dieser Arbeit, die Bedeutung parakriner Einflüsse auf Differenzierungsvorgänge von Chondrozyten, chondrogenen Progenitorzellen aus osteoarthrotischem Gelenkknorpel und mesenchymalen Stammzellen $\mathrm{zu}$ analysieren. In 3D-Ko-Kulturen wurden die parakrinen Interaktionen der drei Zellreihen untersucht. In weiteren Experimenten erfolgte die Untersuchung parakriner Einflüsse von durch osteoarthrotischen Gelenkknorpel konditionierten Medien auf die Zellen.

Durch umfangreiche vergleichende PCR-Analysen der mRNA-Expresssionsmuster chondraler und osteoblastärer Markergene wurde die Differenzierung der Zellen untersucht und charakterisiert. Kurz- und langfristige Analysen der Expressionslevel von Kollagen I, Runx2, Aggrecan und Sox9 erfolgten zu jedem Zeitpunkt in Relation zu parallel durchgeführten Kontrollkulturen.

In vitro konnte so gezeigt werden, dass mesenchymale Stammzellen in 3D-Ko-Kultur mit Chondrozyten ein gemischt chondrogenes und osteogen-fibroblastenartiges Expressionsmuster entwickeln, welches große Parallelen zum originären Phänotyp der chondrogenen Progenitorzellen aufweist.

Die chondrogenen Progenitorzellen charakterisiert eine stabile Ausprägung ihres Phänotyps in der Osteoarthrose. Auch unter dem Einfluss von Chondrozyten bewahren sie ein konstantes mRNA-Expressionsmuster ohne zusätzlich chondrogenen Effekt, worin sich ihre Stabilität auch im Umfeld der Osteoarthrose widerspiegelt.

Als Mediator einer parakrinen Modulation können chondrogene Progenitorzellen in 3DKo-Kultur initial eine Steigerung der Chondrogenität von Chondrozyten unter zeitgleicher Repression osteogener und fibroblastenartiger Differenzierung bewirken.

Vor dem Hintergrund wachsender Bedeutung von Stammzellen als Mediatoren mit positivem Einfluss auf residente, ausdifferenzierte Zellen im Rahmen zellbasierter Therapien zeigen sich weitere wichtige Parallelen von chondrogenen Progenitorzellen zu mesenchymalen Stammzellen. 
Die parakrinen Einflüsse osteoarthrotischen Gelenkknorpels auf die untersuchten Zellen sind weitestgehend unabhängig vom makroskopischen Ausmaß der Degradation des Knorpels. Das bedeutet auf parakriner Ebene einen neuen und weiteren Beleg dafür, dass die Osteoarthrose eine den gesamten Gelenkknorpel betreffende Erkrankung darstellt.

In Zusammenschau legen die Untersuchungen nahe, dass chondrogene Progenitorzellen in ihrer Entwicklung aus mesenchymalen Vorläuferzellen entstehen. Mesenchymale Stammzellen würden im Rahmen einer eventuellen Nutzung im tissue engineering in vivo den prägenden Einflüssen des pathologisch veränderten Osteoarthrose-Gelenkmilieus ausgesetzt und darunter ähnliche Differenzierungsprozesse unterlaufen, wie es chondrogene Progenitorzellen schon getan haben.

Aufgrund ihres hohen chondrogenen Differenzierungspotentials und ihrer Stabilität im Osteoarthrose-Gelenk erscheinen chondrogene Progenitorzellen als potentielle Ausgangszellen für eine Regeneration im osteoarthrotischen Gelenk geeignet. 


\section{Literaturverzeichnis}

Abdallah BM, Kassem M (2009): The use of mesenchymal (skeletal) stem cells for treatment of degenerative diseases: current status and future perspectives. J Cell Physiol $\underline{218}, 9-12$

Aigner T, Gerwin N (2007): Growth plate cartilage as developmental model in osteoarthritis research--potentials and limitations. Curr Drug Targets $\underline{8}, 377-385$

Aigner T, Söder S, Gebhard PM, McAlinden A, Haag J (2007): Mechanisms of disease: role of chondrocytes in the pathogenesis of osteoarthritis--structure, chaos and senescence. Nat Clin Pract Rheumatol $\underline{3}, 391-399$

Alsalameh S, Amin R, Gemba T, Lotz, M (2004): Identification of mesenchymal progenitor cells in normal and osteoarthritic human articular cartilage. Arthritis Rheum $\underline{50}, 1522-1532$

Altman R, Asch E, Bloch D, Bole G, Borenstein D, Brandt K, Christy W, Cooke TD, Greenwald R, Hochberg, M (1986): Development of criteria for the classification and reporting of osteoarthritis. Classification of osteoarthritis of the knee. Diagnostic and Therapeutic Criteria Committee of the American Rheumatism Association. Arthritis Rheum 29, 1039-1049

Archer CW, Francis-West P (2003): The chondrocyte. Int J Biochem Cell Biol 35, 401404

Arthur A, Zannettino A, Gronthos S (2009): The therapeutic applications of multipotential mesenchymal/stromal stem cells in skeletal tissue repair. J Cell Physiol 218, 237-245

Aung A, Gupta G, Majid G, Varghese S (2011): Osteoarthritic chondrocyte-secreted morphogens induce chondrogenic differentiation of human mesenchymal stem cells. Arthritis Rheum $\underline{63}, 148-158$

Barry F, Murphy M (2013): Mesenchymal stem cells in joint disease and repair. Nat Rev Rheumatol $\underline{9}, 584-594$

Barry F (2003): Biology and clinical applications of mesenchymal stem cells. Birth Defects Res C Embryo Today 69, 250-256 
Behonick DJ, Werb Z (2003): A bit of give and take: the relationship between the extracellular matrix and the developing chondrocyte. Mech Dev $\underline{120}, 1327-1336$

Benito MJ, Veale DJ, FitzGerald O, Van den Berg WB, Bresnihan B (2005): Synovial tissue inflammation in early and late osteoarthritis. Ann Rheum Dis $\underline{64}, 1263-1267$

Benya PD, Shaffer JD (1982): Dedifferentiated chondrocytes reexpress the differentiated collagen phenotype when cultured in agarose gels. Cell $\underline{30}, 215-224$

Bobick BE, Chen FH, Le AM, Tuan RS (2009): Regulation of the chondrogenic phenotype in culture. Birth Defects Res C Embryo Today $\underline{87}$, 351-371

Böcker W, Yin Z, Drosse I, Haasters F, Rossmann O, Wierer M, Popov C, Locher M, Mutschler W, Docheva D et al. (2008): Introducing a single-cell-derived human mesenchymal stem cell line expressing hTERT after lentiviral gene transfer. J Cell Mol Med $\underline{12}, 1347-1359$

Bruckner P, Van der Rest M (1994): Structure and function of cartilage collagens. Microsc Res Tech $\underline{28}, 378-384$

Buckwalter JA, Mankin HJ (1998): Articular cartilage: tissue design and chondrocytematrix interactions. Instr Course Lect $\underline{47}, 477-486$

Bullough P, Goodfellow J (1968): The significance of the fine structure of articular cartilage. J Bone Joint Surg Br $\underline{50}, 852-857$

Cameron DA, Robinson RA (1958): Electron microscopy of epiphyseal and articular cartilage matrix in the femur of the newborn infant. J Bone Joint Surg Am $\underline{40-A, 163-170}$

Caplan AI (2007): Adult mesenchymal stem cells for tissue engineering versus regenerative medicine. J Cell Physiol 213, 341-347

Caplan AI (2009): New era of cell-based orthopedic therapies. Tissue Eng Part B Rev $\underline{15}$, 195-200

Caplan AI, Dennis JE (2006): Mesenchymal stem cells as trophic mediators. J Cell Biochem 98, 1076-1084 
Carrington JL (2005): Aging bone and cartilage: cross-cutting issues. Biochem Biophys Res Commun $\underline{328}$, 700-708

Cawston TE, Wilson AJ (2006): Understanding the role of tissue degrading enzymes and their inhibitors in development and disease. Best Pract Res Clin Rheumatol 20, 983-1002

Chen WH, Lai MT, Wu ATH, Wu CC, Gelovani JG, Lin CT, Hung SC, Chiu WT, Deng WP (2009): In vitro stage-specific chondrogenesis of mesenchymal stem cells committed to chondrocytes. Arthritis Rheum $\underline{60}, 450-459$

DeLise AM, Fischer L, Tuan RS (2000): Cellular interactions and signaling in cartilage development. Osteoarthr Cartil $\underline{8}, 309-334$

Diao HJ, Yeung CW, Yan CH, Chan GCF, Chan BP (2013): Bidirectional and mutually beneficial interactions between human mesenchymal stem cells and osteoarthritic chondrocytes in micromass co-cultures. Regen Med $\underline{8}, 257-269$

Diekman BO, Guilak F (2013): Stem cell-based therapies for osteoarthritis: Challenges and opportunities. Curr Opin Rheumatol 25, 119-126

Dijkgraaf LC, De Bont LG, Boering G, Liem RS (1995): Normal cartilage structure, biochemistry, and metabolism: a review of the literature. J Oral Maxillofac Surg $\underline{53}$, 924929

Eyre D (2002): Collagen of articular cartilage. Arthritis Res $\underline{4}, 30-35$

Eyre D (2004): Collagens and cartilage matrix homeostasis. Clin Orthop Relat Res $\underline{427}$, $118-122$

Felson DT (2006): Clinical practice. Osteoarthritis of the knee. N Engl J Med $\underline{354}$, 841848

Fischer J, Dickhut A, Rickert M, Richter W (2010): Human articular chondrocytes secrete parathyroid hormone-related protein and inhibit hypertrophy of mesenchymal stem cells in coculture during chondrogenesis. Arthritis Rheum $\underline{62}$, 2696-2706

Fortier LA, Barker JU, Strauss EJ, McCarrel TM, Cole BJ (2011): The role of growth factors in cartilage repair. Clin Orthop Relat Res $\underline{469}, 2706-2715$ 
Gelse K, Pöschl E, Aigner T (2003): Collagens--structure, function, and biosynthesis. Adv Drug Deliv Rev 55, 1531-1546

Gerber HP, Vu TH, Ryan AM, Kowalski J, Werb Z, Ferrara N (1999): VEGF couples hypertrophic cartilage remodeling, ossification and angiogenesis during endochondral bone formation. Nat Med $\underline{5}$, 623-628

Gerstenfeld LC, Cruceta J, Shea CM, Sampath K, Barnes GL, Einhorn TA (2002):

Chondrocytes provide morphogenic signals that selectively induce osteogenic differentiation of mesenchymal stem cells. J Bone Miner Res 17, 221-230

Gerter R, Kruegel J, Miosge N (2012) New insights into cartilage repair - the role of migratory progenitor cells in osteoarthritis. Matrix Biol $\underline{31}, 206-213$

Goldring MB (2012): Chondrogenesis, chondrocyte differentiation, and articular cartilage metabolism in health and osteoarthritis. Ther Adv Musculoskelet Dis $\underline{4}, 269-285$

Goldring MB, Goldring SR (2007): Osteoarthritis. J Cell Physiol 213, 626-634

Goldring MB, Marcu KB (2009): Cartilage homeostasis in health and rheumatic diseases. Arthritis Res Ther $\underline{11}, 224$

Goldring MB, Tsuchimochi K, Ijiri K (2006): The control of chondrogenesis. J Cell Biochem 97, 33-44

Goldring SR, Goldring MB (2006): Clinical aspects, pathology and pathophysiology of osteoarthritis. J Musculoskelet Neuronal Interact $\underline{6}$, 376-378

Grässel S, Ahmed N (2007): Influence of cellular microenvironment and paracrine signals on chondrogenic differentiation. Front Biosci $\underline{12}$, 4946-4956

Grässel S, Rickert M, Opolka A, Bosserhoff A, Angele P, Grifka J, Anders S (2010): Coculture between periosteal explants and articular chondrocytes induces expression of TGF-beta1 and collagen I. Rheumatology (Oxford) 49, 218-230

Gronthos S, Zannettino ACW, Hay SJ, Shi S, Graves SE, Kortesidis A, Simmons PJ (2003): Molecular and cellular characterisation of highly purified stromal stem cells derived from human bone marrow. J Cell Sci 116, 1827-1835 
Häuselmann HJ, Aydelotte MB, Schumacher BL, Kuettner KE, Gitelis SH, Thonar EJ (1992): Synthesis and turnover of proteoglycans by human and bovine adult articular chondrocytes cultured in alginate beads. Matrix $\underline{12}, 116-129$

Heldens GTH, Blaney Davidson EN, Vitters EL, Schreurs BW, Piek E, Van den Berg WB, Van der Kraan PM (2012): Catabolic factors and osteoarthritis-conditioned medium inhibit chondrogenesis of human mesenchymal stem cells. Tissue Eng Part A $\underline{18}, 45-54$

Horton WE Jr, Bennion P, Yang L (2006): Cellular, molecular, and matrix changes in cartilage during aging and osteoarthritis. J Musculoskelet Neuronal Interact $\underline{6}, 379-381$

Huch K, Stöve J, Puhl W, Günther KP (2002): Vergleichender Überblick über Verfahren zur Kultivierung artikulärer Chondrozyten. Zeitschrift Für Orthopädie $\underline{140}$, 145-152

Hunziker EB (1994): Mechanism of longitudinal bone growth and its regulation by growth plate chondrocytes. Microsc Res Tech $\underline{28}, 505-519$

Hwang NS, Varghese S, Puleo C, Zhang Z, Elisseeff J (2007): Morphogenetic signals from chondrocytes promote chondrogenic and osteogenic differentiation of mesenchymal stem cells. J Cell Physiol 212, 281-284

Iozzo RV (1998): Matrix proteoglycans: from molecular design to cellular function. Annu Rev Biochem 67, 609-652

Jikko A, Kato Y, Hiranuma H, Fuchihata H (1999): Inhibition of chondrocyte terminal differentiation and matrix calcification by soluble factors released by articular chondrocytes. Calcif Tissue Int $\underline{65}$, 276-279

Johnstone B, Hering TM, Caplan AI, Goldberg VM, Yoo JU (1998): In vitro chondrogenesis of bone marrow-derived mesenchymal progenitor cells. Exp Cell Res 238, $265-272$

Jordan KM, Arden NK, Doherty M, Bannwarth B, Bijlsma JWJ, Dieppe P, Gunther K, Hauselmann H, Herrero-Beaumont G, Kaklamanis P et al. (2003): EULAR Recommendations 2003: an evidence based approach to the management of knee 
osteoarthritis: Report of a Task Force of the Standing Committee for International Clinical Studies Including Therapeutic Trials (ESCISIT). Ann Rheum Dis $\underline{62}, 1145-1155$

Kaplan JM, Youd ME, Lodie TA (2011): Immunomodulatory activity of mesenchymal stem cells. Curr Stem Cell Res Ther $\underline{6}, 297-316$

Karlsson C, Brantsing C, Svensson T, Brisby H, Asp J, Tallheden T, Lindahl A (2007): Differentiation of human mesenchymal stem cells and articular chondrocytes: analysis of chondrogenic potential and expression pattern of differentiation-related transcription factors. J Orthop Res $\underline{25}, 152-163$

Kassem M, Abdallah BM (2008): Human bone-marrow-derived mesenchymal stem cells: biological characteristics and potential role in therapy of degenerative diseases. Cell Tissue Res $\underline{331}, 157-163$

Kellgren JH, Lawrence JS (1957): Radiological assessment of osteo-arthrosis. Ann Rheum Dis $\underline{16}, 494-502$

Khan IM, Williams R, Archer CW (2009): One flew over the progenitor's nest: migratory cells find a home in osteoarthritic cartilage. Cell Stem Cell $\underline{4}, 282-284$

Kobayashi T, Chung UI, Schipani E, Starbuck M, Karsenty G, Katagiri T, Goad DL, Lanske B, Kronenberg HM (2002): PTHrP and Indian hedgehog control differentiation of growth plate chondrocytes at multiple steps. Development $\underline{129}$, 2977-2986

Koelling S, Miosge N (2009): Stem cell therapy for cartilage regeneration in osteoarthritis. Expert Opin Biol Ther $\underline{9}, 1399-1405$

Koelling S, Kruegel J, Irmer M, Path JR, Sadowski B, Miro X, Miosge N (2009): Migratory chondrogenic progenitor cells from repair tissue during the later stages of human osteoarthritis. Cell Stem Cell $\underline{4}, 324-335$

Kruegel J, Miosge N (2010): Basement membrane components are key players in specialized extracellular matrices. Cell Mol Life Sci $\underline{67}, 2879-2895$

Kuettner KE (1992) Biochemistry of articular cartilage in health and disease. Clin Biochem 25, 155-163 
Lefebvre V, Smits P (2005): Transcriptional control of chondrocyte fate and differentiation. Birth Defects Res C Embryo Today 75, 200-212

Loeser RF (2009): Aging and osteoarthritis: the role of chondrocyte senescence and aging changes in the cartilage matrix. Osteoarthr Cartil $\underline{17}, 971-979$

Lohmander LS, Roos EM (2007): Clinical update: treating osteoarthritis. Lancet $\underline{370}$, 2082-2084

Lotz MK, Otsuki S, Grogan SP, Sah R, Terkeltaub R, D’Lima D (2010): Cartilage cell clusters. Arthritis Rheum $\underline{62}$, 2206-2218

Mabvuure N, Hindocha S, Jordan D, Khan WS (2012): Chondrogenesis and developments in our understanding. Curr Stem Cell Res Ther $\underline{7}, 243-259$

Maletius W, Aigner T (1999): Morphologie und Molekularpathologie der Osteoarthrose. Arthroskopie $\underline{12}, 3-8$

Maroudas A, Bayliss MT, Venn MF (1980): Further studies on the composition of human femoral head cartilage. Ann Rheum Dis $\underline{39}, 514-523$

Martel-Pelletier J, Boileau C, Pelletier JP, Roughley PJ (2008): Cartilage in normal and osteoarthritis conditions. Best Pract Res Clin Rheumatol 22, 351-384

Martinek V (2003): Anatomie und Pathophysiologie des hyalinen Knorpels. Deutsche Zeitschrift für Sportmedizin $\underline{54}$, 166-170

Mayne R, Brewton RG (1993): New members of the collagen superfamily. Curr Opin Cell Biol $\underline{5}, 883-890$

McDevitt CA (1973): Biochemistry of articular cartilage. Nature of proteoglycans and collagen of articular cartilage and their role in ageing and in osteoarthrosis. Ann Rheum Dis $\underline{32}, 364-378$

Meretoja VV, Dahlin RL, Kasper FK, Mikos AG (2012): Enhanced chondrogenesis in cocultures with articular chondrocytes and mesenchymal stem cells. Biomaterials $\underline{33}, 6362-$ 6369 
Minina E, Kreschel C, Naski MC, Ornitz DM, Vortkamp A (2002): Interaction of FGF, Ihh/Pthlh, and BMP signaling integrates chondrocyte proliferation and hypertrophic differentiation. Dev Cell $\underline{3}, 439-449$

Miosge N, Flachsbart K, Goetz W, Schultz W, Kresse H, Herken R (1994): Light and electron microscopical immunohistochemical localization of the small proteoglycan core proteins decorin and biglycan in human knee joint cartilage. Histochem J 26, 939-945

Miosge N, Hartmann M, Maelicke C, Herken R (2004): Expression of collagen type I and type II in consecutive stages of human osteoarthritis. Histochem Cell Biol 122, 229-236

Mo X, Guo S, Xie H, Deng L, Zhi W, Xiang Z, Li X, Yang Z (2009): Variations in the ratios of co-cultured mesenchymal stem cells and chondrocytes regulate the expression of cartilaginous and osseous phenotype in alginate constructs. Bone $\underline{45}, 42-51$

Mow VC, Holmes MH, Lai WM (1984): Fluid transport and mechanical properties of articular cartilage: a review. J Biomech $\underline{17}, 377-394$

Muhammad H, Schminke B, Miosge N (2013): Current concepts in stem cell therapy for articular cartilage repair. Expert Opin Biol Ther 13, 541-548

Muir H (1995): The chondrocyte, architect of cartilage. Biomechanics, structure, function and molecular biology of cartilage matrix macromolecules. Bioessays $\underline{17}, 1039-1048$

Nerlich AG, Wiest I, Von der Mark K (1993): Immunohistochemical analysis of interstitial collagens in cartilage of different stages of osteoarthrosis. Virchows Arch, B, Cell Pathol $\underline{63}, 249-255$

Onyekwelu I, Goldring MB, Hidaka C (2009): Chondrogenesis, joint formation, and articular cartilage regeneration. J Cell Biochem 107, 383-392

Otte P: Der Arthrose Prozeß. Teil I Gelenkerhaltung-Gefährdung-Destruktion, Teil 1:

Osteochondrale Strukturen. 2. Auflage; Novartis Pharma Verlag, Nürnberg 2001

Pfaffl MW (2004): Real-time RT-PCR: Neue Ansätze zur exakten mRNA Quantifizierung. BIOspektrum $\underline{1}, 92-95$ 
Pittenger MF, Mackay AM, Beck SC, Jaiswal RK, Douglas R, Mosca JD, Moorman MA, Simonetti DW, Craig S, Marshak DR (1999): Multilineage potential of adult human mesenchymal stem cells. Science $\underline{284}, 143-147$

Poole CA (1997): Articular cartilage chondrons: form, function and failure. J Anat $\underline{191}$ ( $P t$ 1), $1-13$

Pritzker KPH, Gay S, Jimenez SA, Ostergaard K, Pelletier JP, Revell PA, Salter D, Van den Berg WB (2006): Osteoarthritis cartilage histopathology: grading and staging. Osteoarthr Cartil $\underline{14}, 13-29$

Prockop DJ, Sekiya I, Colter DC (2001): Isolation and characterization of rapidly selfrenewing stem cells from cultures of human marrow stromal cells. Cytotherapy $\underline{3}$, 393-396 Pullig O, Pfander D, Swoboda B (2001): Molekulare Grundlagen der Arthroseinduktion und -progression. Orthopäde $\underline{30}, 825-833$

Reginster JY, Khaltaev NG (2002): Introduction and WHO perspective on the global burden of musculoskeletal conditions. Rheumatology (Oxford) $\underline{41}$ Supp 1, 1-2

Rothenberg AR, Ouyang L, Elisseeff JH (2011): Mesenchymal stem cell stimulation of tissue growth depends on differentiation state. Stem Cells Dev 20, 405-414

Roughley PJ (2001): Articular cartilage and changes in arthritis: noncollagenous proteins and proteoglycans in the extracellular matrix of cartilage. Arthritis Res $\underline{3}, 342-347$

Roughley PJ (2006): The structure and function of cartilage proteoglycans. Eur Cell Mater $\underline{12}, 92-101$

Sanchez C, Deberg MA, Piccardi N, Msika P, Reginster JY, Henrotin YE (2005) Subchondral bone osteoblasts induce phenotypic changes in human osteoarthritic chondrocytes. Osteoarthr Cartil $\underline{13}, 988-997$

Sandell LJ (2007): Modern molecular analysis of a traditional disease: progression in osteoarthritis. Arthritis Rheum $\underline{56}, 2474-2477$

Sandell LJ, Aigner T (2001): Articular cartilage and changes in Arthritis: Cell biology of osteoarthritis. Arthritis Res $\underline{3}, 107-113$ 
Sato T, Konomi K, Yamasaki S, Aratani S, Tsuchimochi K, Yokouchi M, Masuko-Hongo K, Yagishita N, Nakamura H, Komiya S et al. (2006): Comparative analysis of gene expression profiles in intact and damaged regions of human osteoarthritic cartilage. Arthritis Rheum 54, 808-817

Schnabel M, Marlovits S, Eckhoff G, Fichtel I, Gotzen L, Vécsei V, and Schlegel J (2002): Dedifferentiation-associated changes in morphology and gene expression in primary human articular chondrocytes in cell culture. Osteoarthr Cartil 10, 62-70

Schulze M, Kuettner KE, and Cole AA (2000): Adulte humane Chondrozyten in Alginatkultur. Beibehaltung des Phänotyps für die weitere Anwendung in Transplantationsmodellen. Orthopade $\underline{29}$, 100-106

Schulze-Tanzil G, De Souza P, Villegas Castrejon H, John T, Merker HJ, Scheid A, Shakibaei M (2002): Redifferentiation of dedifferentiated human chondrocytes in highdensity cultures. Cell Tissue Res $\underline{308}$, 371-379

Takada I, Kouzmenko AP, Kato S (2009): Wnt and PPARgamma signaling in osteoblastogenesis and adipogenesis. Nat Rev Rheumatol 5, 442-447

Tallheden T, Karlsson C, Brunner A, Van Der Lee J, Hagg R, Tommasini R, Lindahl A (2004): Gene expression during redifferentiation of human articular chondrocytes.

Osteoarthr Cartil $\underline{12}, 525-535$

Tamamura Y, Otani T, Kanatani N, Koyama E, Kitagaki J, Komori T, Yamada Y, Costantini F, Wakisaka S, Pacifici M et al. (2005). Developmental regulation of Wnt/betacatenin signals is required for growth plate assembly, cartilage integrity, and endochondral ossification. J Biol Chem 280, 19185-19195

Tesche F, Miosge N (2005): New aspects of the pathogenesis of osteoarthritis: the role of fibroblast-like chondrocytes in late stages of the disease. Histol Histopathol 20, 329-337

Tuan RS, Boland G, Tuli R (2003): Adult mesenchymal stem cells and cell-based tissue engineering. Arthritis Res Ther $\underline{5}, 32-45$

Tuli R, Li WJ, Tuan RS (2003): Current state of cartilage tissue engineering. Arthritis Res Ther $\underline{5}, 235-238$ 
Umlauf D, Frank S, Pap T, Bertrand J (2010): Cartilage biology, pathology, and repair. Cell Mol Life Sci 67, 4197-4211

Van den Berg WB, Van der Kraan PM, Scharstuhl A, Van Beuningen HM (2001): Growth factors and cartilage repair. Clin Orthop Relat Res $\underline{391}$, 244-250

Van der Kraan PM (2012): Osteoarthritis year 2012 in review: biology. Osteoarthr Cartil $\underline{20}, 1447-1450$

Van der Kraan PM, Buma P, Van Kuppevelt T, Van den Berg WB (2002): Interaction of chondrocytes, extracellular matrix and growth factors: relevance for articular cartilage tissue engineering. Osteoarthr Cartil $\underline{10}, 631-637$

Varghese S, Hwang NS, Ferran A, Hillel A, Theprungsirikul P, Canver AC, Zhang Z, Gearhart J, Elisseeff J (2010): Engineering musculoskeletal tissues with human embryonic germ cell derivatives. Stem Cells $\underline{28}, 765-774$

Von der Mark K, Glückert K (1990): Biochemical and molecular biologic aspects of early detection of human arthroses. Orthopade $\underline{19}, 2-15$

Von der Mark K, Kirsch T, Nerlich A, Kuss A, Weseloh G, Glückert K, Stöss H (1992): Type X collagen synthesis in human osteoarthritic cartilage. Indication of chondrocyte hypertrophy. Arthritis Rheum $\underline{35}$, 806-811

Walsh DA, Bonnet CS, Turner EL, Wilson D, Situ M, McWilliams DF (2007): Angiogenesis in the synovium and at the osteochondral junction in osteoarthritis. Osteoarthr Cartil $\underline{15}, 743-751$

Woolf AD, Pfleger B (2003): Burden of major musculoskeletal conditions. Bull World Health Organ $\underline{81}, 646-656$

Wu JJ, Woods PE, Eyre DR (1992): Identification of cross-linking sites in bovine cartilage type IX collagen reveals an antiparallel type II-type IX molecular relationship and type IX to type IX bonding. J Biol Chem 267, 23007-23014

Wu L, Prins HJ, Helder MN, Van Blitterswijk CA, Karperien M (2012): Trophic effects of mesenchymal stem cells in chondrocyte co-cultures are independent of culture conditions and cell sources. Tissue Eng Part A $\underline{18}, 1542-1551$ 
Wu, W, Billinghurst RC, Pidoux I, Antoniou J, Zukor D, Tanzer M, Poole AR (2002):

Sites of collagenase cleavage and denaturation of type II collagen in aging and osteoarthritic articular cartilage and their relationship to the distribution of matrix metalloproteinase 1 and matrix metalloproteinase 13. Arthritis Rheum $\underline{46}$, 2087-2094

Zuo Q, Cui W, Liu F, Wang Q, Chen Z, Fan W (2013): Co-cultivated mesenchymal stem cells support chondrocytic differentiation of articular chondrocytes. Int Orthop $\underline{37}, 747-$ 752 


\section{Abbildungs- und Tabellenverzeichnis}

Abbildung 1: $\quad$ Prozess und Kontrolle der Chondrogenese

Abbildung 2: $\quad$ Chondrozytäre Einflüsse und Reaktionen in der Pathogenese der Osteoarthrose

Abbildung 3: $\quad$ CPC-Migration aus osteoarthrotisch degradiertem Gelenkknorpel in vitro

Abbildung 4: $\quad$ Differenzierungsmöglichkeiten der mesenchymalen Stammzellen (MSC)

Abbildung 5: $\quad$ Schema Versuchsaufbau 3D-Ko-Kultur

Abbildung 6: $\quad$ Schema Versuchsaufbau 3D-Kultur in konditionierten Medien

Abbildung 7: qRT-PCR-Analyse des Einflusses von CPC auf gG-Zellen in 3D-KoKultur - Ergebnisse nach 7 Tagen

Abbildung 8: qRT-PCR Analyse des Einflusses von CPC auf gG-Zellen in 3D-KoKultur - Ergebnisse nach 21 Tagen

Abbildung 9: qRT-PCR Analyse des Einflusses von R-Medium auf gG-Zellen in 3D-Kultur - Ergebnisse nach 7 und 21 Tagen

Abbildung 10: $\quad$ qRT-PCR Analyse des Einflusses von MSC auf gG-Zellen in 3DKo-Kultur- Ergebnisse nach 7 Tagen 
Abbildung 11: $\quad$ qRT-PCR Analyse des Einflusses von MSC auf gG-Zellen in 3DKo-Kultur- Ergebnisse nach 21 Tagen

S. 48

Abbildung 12: $\quad$ qRT-PCR Analyse des Einflusses von gG-Zellen auf CPC in 3D-KoKultur- Ergebnisse nach 7 und 21 Tagen

Abbildung 13: $\quad$ qRT-PCR Analyse des Einflusses von gG-Zellen auf MSC in 3DKo-Kultur- Ergebnisse nach 7 und 21 Tagen

S. 50

Abbildung 14: $\quad$ qRT-PCR Analyse des Expressionsverhaltens von MSC in 3D-KoKultur mit CPC - Ergebnisse nach 7 und 21 Tagen

S. 51

Abbildung 15: $\quad$ qRT-PCR Analyse des Expressionsverhaltens von CPC in 3D-KoKultur mit MSC - Ergebnisse nach 7 Tagen

S. 52

Abbildung 16: $\quad$ qRT-PCR Analyse des Expressionsverhaltens von CPC in 3D-KoKultur mit MSC - Ergebnisse nach 21 Tagen

Abbildung 17: $\quad$ qRT-PCR Analyse des Einflusses von G-konditioniertem Medium auf gG-Zellen in 3D-Kultur - Ergebnisse nach 7 und 21 Tagen

Abbildung 18: $\quad$ qRT-PCR Analyse des Einflusses von R-konditioniertem Medium auf gG-Zellen in 3D-Kultur - Ergebnisse nach 7 und 21 Tagen

S. 56 
Tabelle 1:

Primerliste mit Angaben der Sequenzen und Annealing-

Temperaturen

S. 41

Tabelle 2: Housekeeping-Gene

S. 43 